
Special Report NSF 88-318
Jun 1988

the science and

technology resources

of japan:

a comparison with

the united states

$Q$

180

. 53

P37

1988
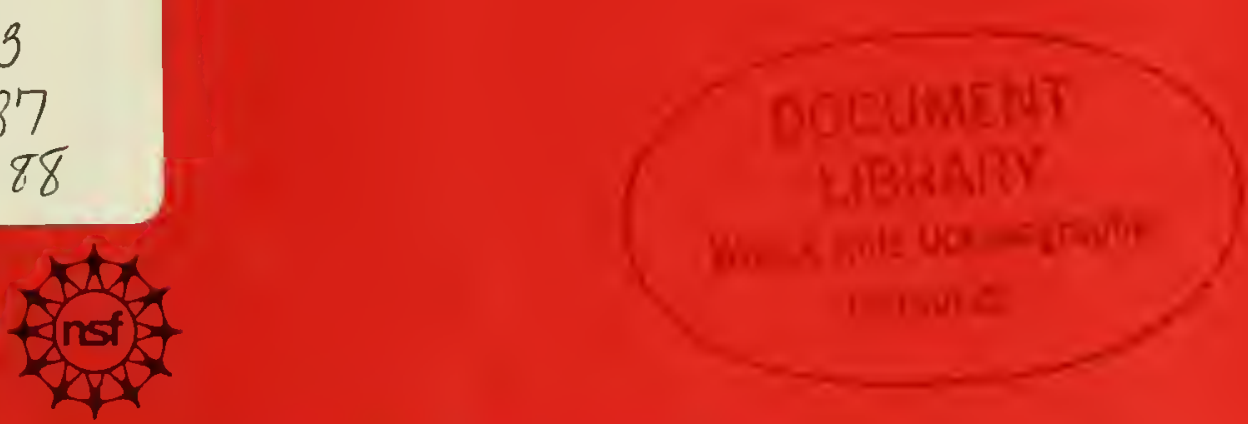

surveys of science resources series national science foundation

special report 


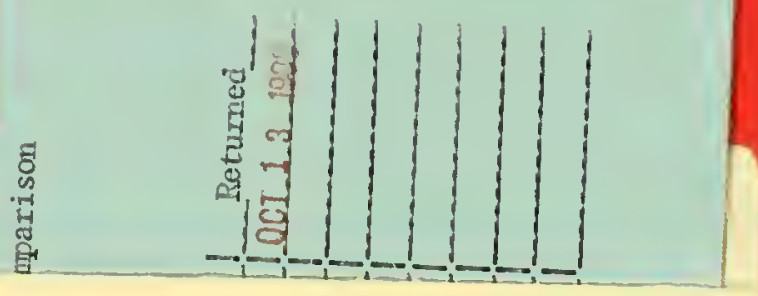

DOCUMENT

LIPRARY

Woods Hole Ocuanoziaphic

Institution

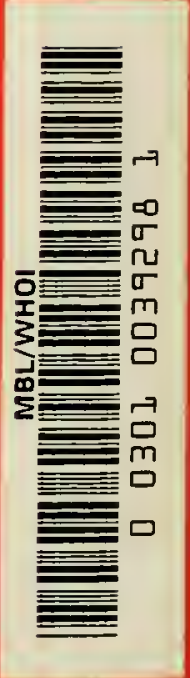




\section{the science and}

technology resources of japan:

a comparison with

the united states

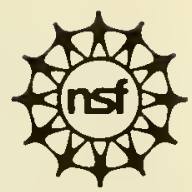

surveys of science resources series national science foundation 


\section{Telephonic Device for the Deaf}

The National Science Foundation has Telephonic Device for the Deaf (TDD) capability which enables individuals with hearing impairment to communicate with the Division of Personnel and Management for information relating to NSF programs, employment, or general information. This number is (202) $357-7492$.

\section{Availability of Publications}

Single copies may be obtained gratis from the National Science Foundation, Washington, D.C. 20550.

\section{Suggested Citation}

National Science Foundation, The Science and Technology Resources of Japan: A Comparison with the United States (NSF 88-318)(Washington, D.C., 1988), 


\section{foreword}

The Division of Science Resources Studies of the National Science Foundation has initiated efforts to obtain more recent and detailed quantitative information on foreign science and technology (S/T) capabilities and activities-principally in the large research and development (R\&D)-performing industrialized nations. This report presents a statistical profile of Japan's S/T efforts since 1965 and compares it with that of the United States. R\&D trends in Japan at the national level as well as for individual sectors are presented, and data on S/T outputs are discussed.

William L. Stewart

Director, Division of

Science Resources Studies

Directorate for Scientific, Technological, and International Affairs

June 1988 


\section{acknowledgments}

This report was prepared by Maria Papadakis, Science Resources Analyst, International Studies Group (IntSG). Earlier work on the report was conducted by William P. Cummings. Supervision, review, and guidance were provided by Jennifer Sue Bond, Study Director, (IntSG), and Leonard Lederman, Head of the Special Analyses and Studies Section, Division of Science Resources Studies. Additional review and assistance were provided by Charles T. Owens, Head, Information and Analysis Section, Division of International Programs, and Alexander P. Deangelis, Head, NSF Tokyo Office.

Efforts are constantly underway to collect the most recent data. Such new data or additional detail may be obtained from the author:

Maria Papadakis

Science Resources Analyst, International Studies Group

Division of Science Resources Studies

(202) 634-4640 


\section{contents}

Introduction

Highlights

Chapter:

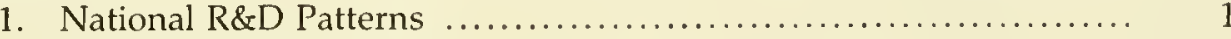

Total R\&D Expenditures ....................................

R\&D Expenditures by Source and Performer ..................... 2

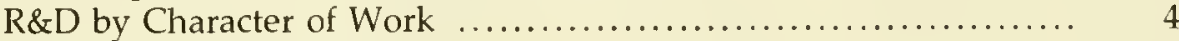

Scientists and Engineers ................................... 5

Technical Know-How Expenditures and Receipts ............... 7

2. Government R\&D .........................................

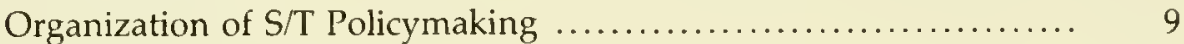

Government Funding ...................................... 13

Government R\&D Programs ................................ 15

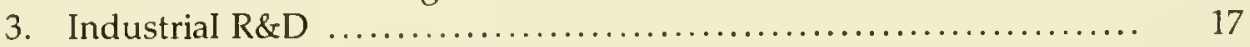

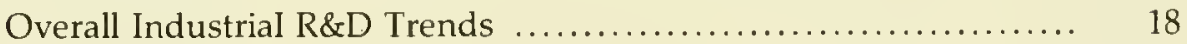

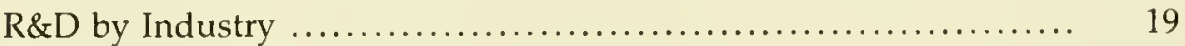

$R \& D$ to Net Sales and R\&D Concentration ................... 20

Industrial Scientists and Engineers Engaged in R\&D ............. 21

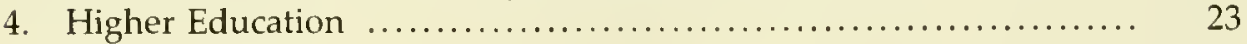

Overall R\&D Trends ...................................... 24

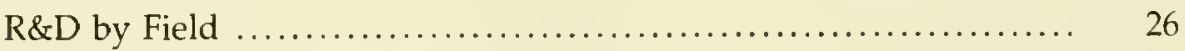

S/E Degree Production ...................................... 27

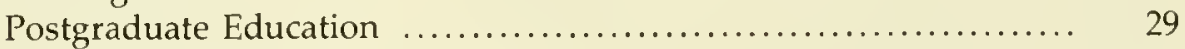

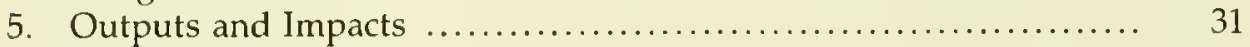

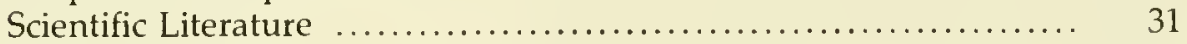

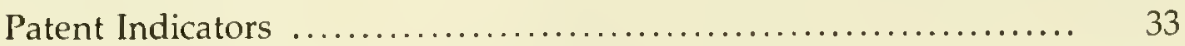

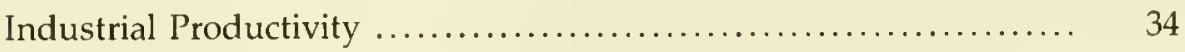

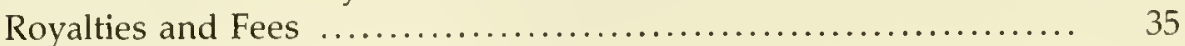

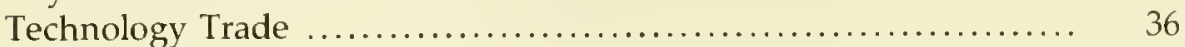

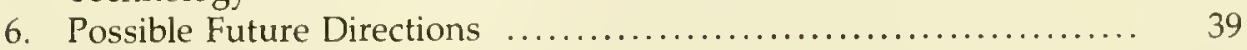

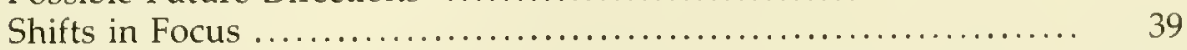

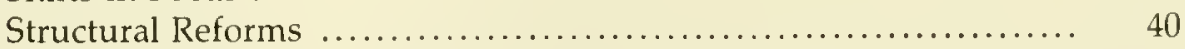

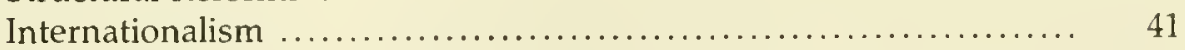

Trends in R\&D Expenditures ............................. 42

Appendixes:

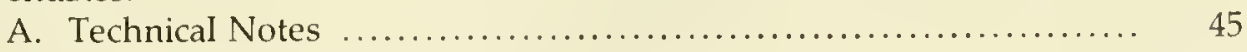

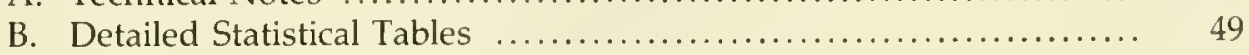

C. Japanese Government Research Programs ....................... 65

D. Awards Under the Specially Promoted Distinguished Research

Program of the Ministry of Education 



\section{introduction}

Japan's postwar research and development (R\&D) efforts have passed through several phases to bring the nation to what may be called "relative parity" with the United States. Almost all key aggregate indicators show that Japan now expends money and supports R\&D personnel in the same proportions as does the United States when the size of the national economies and populations are taken into account. In some instances, such as the ratio of company-funded $R \& D$ to gross national product (GNP) and nondefense R\&D to GNP, Japan's performance has exceeded that of the United States for a number of years.

Given the Japanese postwar economic record, this achievement is not surprising. What is remarkable, however, is that the rate of growth in Japanese $R \& D$ expenditures exceeded the high average annual increase in GNP by more than 3 percentage points during the years 1965 to 1986 . Such a financial commitment, coupled with Japan's strong emphasis on education, has enabled the country to expand its science and technology (S/T) resources from a fraction of the United States to one of relative parity.

The Japanese R\&D system is characterized by some major differences from that in the United States. In Japan, private industry plays a more dominant funding role: industry is by far the largest source of national R\&D funds, accounting for 69 percent of R\&D funding and 67 percent of R\&D performance in 1985 . In contrast, U.S. industry provided 49 percent of R\&D funds and accounted for 73 percent of R\&D performance. These figures suggest an additional distinction in corporate $R \& D$ between the two countries; in Japan, industrial R\&D is
97-98 percent company-funded compared to 66 percent in the United States (to some extent, this reflects the higher levels of U.S. Government funding of defenserelated $R \& D$ in industry).

The Japanese Government plays a relatively smaller role in the direct funding of $R \& D$ in Japan than does the Federal Government in the United States. In Japan, the government was the source of 21 percent of R\&D funds in 1985, whereas the U.S. Federal Government was the source of 48 percent of R\&D funds in the United States. This significant difference is largely attributable to two factors. First, defense expenditures typically have been low in Japan and in fact were restricted from 1976 to 1986; consequently, less than 1 percent of Japanese R\&D expenditures was devoted to defense purposes, compared to 30 percent in the United States. ' Second, the Japanese Government traditionally has not provided R\&D funding to industry, a policy which, combined with Japanese fiscal restraint, has resulted in a fairly limited transfer of $R \& D$ funds between these two sectors.

${ }^{1}$ Under the Japanese constitution-which was designed by American officials controlling Occupied Japan-Japan renounced the threat or use of force. Consequently, Japanese military forces are essentially limited to defensive capabilities. Two subsequent U.S.-Japanese security treaties (in 1951 and 1960) outlined the nature of the military/defense relationship between the two countries. Throughout the postwar era, Japan has made policy decisions limiting the scope of its domestic defense forces and defense industry, culminating in the 1976 policies of restricting defense expenditures to 1 percent of GNP and prohibiting most arms sales abroad. Although the "1-percent rule" was revoked in 1986, there are no immediate plans to increase defense expenditures significantly above 1 percent of GNP. Japanese defense expenditures consistently have been equivalent to about 1 percent of GNP since 1965. 
For virtually all other major S/T indicators, Japan and the United States now demonstrate similar characteristics. For example, both countries have virtually the same ratio of R\&D to GNP (2.7-2.8 percent); both distribute their R\&D funds in similar proportions across basic and applied research and development; both have approximately the same number of $R \& D$ scientists and engineers per 10,000 labor force; and so on. In the years since World War II, Japan has turned itself into the world's second largest market economy, and its $\mathrm{S} / \mathrm{T}$ indicators reflect the level of effort of a mature industrial economy.

Unlike the major $\mathrm{S} / \mathrm{T}$ input indicators, Japan and the United States have less similar experiences with their output and impact indicator performance. Japan's share of the world's scientific literature increased slightly (from 5 percent to 7 percent) during 1973-82, while the U.S. share remained fairly constant at 37-39 percent. Over the 1970-86 period, Japan's share of patents granted annually in the U.S. patent system increased from 4 percent to 19 percent; the U.S share declined from 73 percent to 54 percent during this period. The trade performance of the two nations in technology-intensive products was similarly inverse: the United States' share of world exports of technology-intensive goods declined slightly from 28 percent in 1965 to 24 percent in 1985; Japan's share almost tripled from 7 percent to 19 percent.

Japan's accomplishments have been the result of several phases of national effort. The first phase of Japan's S/T efforts, which occurred from the immediate postwar period through the early sixties, did not involve indigenous $R \& D$ investment so much as a reorientation of Japanese industry. Throughout the period, there was large-scale financial investment aimed at transforming Japan's economy from light manufactures to heavy industry. The acquisition of foreign technology was an integral part of this strategy, and technology was purchased which would allow Japan to both manufacture new products and introduce new techniques for the production of existing goods. Once the new industrial base was established, Japan embarked on its own research and technology development.

This report is concerned with Japanese S/T efforts following the "pre-R\&D" era, and provides a quantita- tive comparison of U.S. and Japanese S/T activity principally for the period 1965-85. (Comprehensive data are available on Japan only through 1985; where 1986 data are available, they are so reported.) The patterns over the 20-year period reveal two distinct phases of R\&D for both countries. In 1965, the United States' R\&D effort was beginning to peak in terms of total constant R\&D expenditures and concentration of R\&D personnel in the labor force; this level of performance bottomed out in the mid- to late seventies and was not regained until the early 1980 's. In contrast, Japanese R\&D grew throughout the period, increasing substantially from 1965 to the midseventies, slowing slightly at that time, and then reestablishing its momentum, as did the United States' R\&D.

Much quantitative information is available on Japan's scientific research and experimental development. While most data for the United States and Japan are directly comparable, there are some definitional differences in particular statistical series; in such cases, emphasis is placed on each country's trends rather than on absolute values. Appendix A, "Technical Notes," details such differences and any adjustments that were made to the Japanese or U.S. data to make them more comparable.

Another comparative problem arises when Japanese expenditures are converted into U.S. dollars. Yen-dollar market exchange rates have become rather volatile, reflecting dynamics that are increasingly independent of the relative purchasing power of the currencies. To avoid the distortions that arise from market exchange rate conversions, purchasing power parities calculated by the Organisation for Economic Co-operation and Development are used to convert yen to dollars. Additionally, GNP implicit price deflators are used to convert current dollars into constant 1982 dollars in order to provide time series data that reflect real, rather than nominal, trends in expenditures. A brief discussion of purchasing power parities is included in appendix A.

This report profiles patterns in the major $R \& D$ performing sectors and analyzes $\mathrm{S} / \mathrm{T}$ output and impact indicators in order to provide a comprehensive comparison of Japanese S/T resources with those of the United States. 


\section{highlights}

\section{national science resource patterns}

- The pace of Japanese R\&D expenditures exceeded that of the growth of the Japanese economy over the period 1965-85. The average annual rate of increase in $R \& D$ was 9.3 percent compared to 6.0 percent for the GNP. In the United States, R\&D efforts expanded at a slightly slower rate than GNP: about 2.5 percent and 2.8 percent, respectively. R\&D expenditures in Japan increased nearly fivefold between 1965 and 1985, from constant (1982) $\$ 6.1$ billion to $\$ 36.0$ billion dollars. During the same period, U.S. investments in R\&D rose 63 percent, increasing from constant $\$ 59.4$ billion to $\$ 96.5$ billion. (See pp. $1-2$.)

- Although U.S. investments in R\&D are nearly three times as high as those of Japan in absolute terms, Japan's investment is now comparable based on the size of its economy. The Japanese $R \& D / G N P$ ratio rose consistently during the past 2 decades, reaching a level of 2.8 percent in 1985 and 1986 . The U.S. ratio, which was 2.8 percent in 1965 , steadily declined to a low of 2.1 percent in 1978 before rising to its $1985-86$ level of 2.7 percent. (See pp. 1-2.)

- Slightly less than 1 percent of total Japanese R\&D expenditures was devoted to defense purposes in 1985, a significant contrast to the 30 -percent figure for the
United States. Consequently, Japan has a higher ratio of nondefense R\&D expenditures to GNP than does the United States. In 1985, the ratios were 2.8 percent and 1.9 percent, respectively, and Japan has maintained a lead in this indicator since at least 1971. In absolute terms, Japan's nondefense R\&D expenditures were one-half of U.S. nondefense R\&D expenditures in 1985. Of Japanese Government R\&D expenditures, 4 percent were devoted to defense-related R\&D, compared to 68 percent in the United States. (See pp. 2 and 14.)

- In Japan, industry is the major source (69 percent) of $R \& D$ funds; in the United States, $R \& D$ is financed almost equally by the Federal Government and industry (48-49 percent each). Both countries exhibit similar patterns of R\&D by performer: in 1985, industry expended the majority of R\&D funds (67 percent for Japanese industry and 73 percent for U.S.), higher education accounted for the second largest share of $R \& D$ expenditures (20 percent and 12 percent, respectively), and government accounted for nearly all of the remainder ( 9 percent and 12 percent, respectively). (See pp. 2-4.) 
- The share of Japanese R\&D devoted to basic research has declined over the past 10 years. In 1975 and 1980, basic research accounted for 15 percent of Japanese R\&D expenditures; however, by 1985 this share had declined slightly to 13 percent. In the United States, basic research as a share of total R\&D remained constant during 1975-85 at 12-13 percent. (Note that the data for Japanese and U.S. basic research are somewhat less comparable than those for total R\&D expenditures.) (See p. 4.)

- By 1985, the distribution of total R\&D funds within the two countries by character of work was very similar. In 1985, Japan devoted 25 percent of its R\&D to applied research and 62 percent to development; these shares for the United States were 22 percent and 66 percent, respectively. (See p.4.)

- Japan traditionally has imported foreign technology to supplement its own R\&D efforts. Japan's expenditures on royalties, licensing fees, and other expenses related to imported technology in 1970 were 57 percent of what the United States spent in the same year for technical know-how. Although Japan has continued to purchase a substantial volume of technical knowhow (payments for royalties and fees increased 71 percent between 1970 and 1985), R\&D has outpaced such expenditures. Consequently, the ratio of Japanese payments for technical know-how to R\&D decreased from 11 percent in 1970 to 7 percent in 1985. Japan's exports of technical know-how increased threefold during 1970-85, improving the percentage of receipts to payments from 14 percent in 1970 to 30 percent in 1985. (See pp. 7-8.)

\section{science and}

\section{engineering (s/e) personnel}

- With about one-half of the U.S. population and labor force, Japan had slightly more than 1.5 million employed nonacademic scientists and engineers in 1985, compared with almost 3.6 million in the United States in 1986. Japan has fewer nonacademic scientists and engineers relative to its labor force than does the United States. This condition is attributable to the lower absolute and relative levels of scientists in Japan than in the United States-Japan had 28 percent as many scientists in 1985 as the United States had in 1986. However, Japan had 187 engineers per 10,000 labor force compared to 183 in the United States. (See pp. 5-6.)

- Both countries experienced significant increases from 1980 to $1985 / 86$ in the stock of nonacademic scientists and engineers relative to increases in the labor force.
The Japanese stock of scientists and engineers grew 61 percent, with the number of scientists doubling (mostly due to increases in computer specialists) and a 50-percent increase in the number of engineers (principally increases in electrical/electronic engineers). The U.S. experience was similar: increases of nearly 50 percent or more were registered in most categories of scientists and engineers, with computer specialists increasing 119 percent and electrical/electronic engineers increasing 50 percent. During this 5-year period, the size of the labor force in both countries increased 5-10 percent. (See p. 6.)

- The total number of Japanese R\&D scientists and engineers engaged in R\&D has tripled since 1965; in 1986 , it was 405,600 -one-half the U.S. 802,300 fulltime equivalent. The ratio of Japanese R\&D scientists and engineers per 10,000 labor force was about onethird the U.S. ratio in 1965, but by 1986 the two ratios were comparable at 67-69 scientists and engineers per 10,000 labor force. (See p. 6.)

\section{government r\&d}

- The Japanese Government's share of total national R\&D funding reached its peak (33 percent) in 1972; since then, it has declined fairly steadily to its 1985 level of 21 percent. The U.S. Government's share of national R\&D funding is much higher, although it also declined between 1970 and 1985, dropping from 57 percent to 48 percent. (See p. 9.)

- Despite its declining relative contribution to total national R\&D resources, the value of Japanese Government expenditures steadily increased during the last 2 decades, reaching constant $\$ 7.6$ billion in 1985 , compared to U.S. Federal funding of constant $\$ 46.0$ billion. (See p. 9.)

- The Japanese Government's S/T budget has received high priority in the last 5 years in spite of an environment of fiscal restraint, and has expanded faster than overall government funding. From 1980 to 1985, Japanese Government R\&D funding increased at an average annual rate of 3 percent compared with a higher 6-percent average annual rate in the United States; however, 90 percent of this growth in U.S. federally funded R\&D is accounted for by defenserelated R\&D expenditures. (See p. 9.)

- S/T policy in Japan is largely the result of four institutions: the Prime Minister's Council for Science and Technology; the Science and Technology Agency (STA); the Ministry of Education, Science, and Culture (Monbusho); and the Ministry of International Trade and Industry (MITI). Monbusho and STA have the largest budgets, accounting for 47 percent and 27 percent, respectively, of the Government's total R\&D budget. 
MITI is the third largest funder (13 percent). (See pp. 9-13.)

- Besides its funding and policymaking roles, the Japanese Government also performs R\&D through more than 80 national institutes and public corporations which conduct ongoing research. There are a number of large-scale, special R\&D programs that have been initiated by STA and MITI; these focus primarily on basic research and development of new technologies. (See p. 15.)

\section{industrial r\&d}

- Industrial R\&D has always been the most prominent sector in the Japanese system, accounting for 69 percent of all R\&D funds in 1985 (compared with 49 percent in the United States). Less than 2 percent of direct industrial $R \& D$ funds comes from the Japanese Government, compared to 35 percent in the United States. (See p. 17.)

- Japanese industrial R\&D expenditures increased at an average annual rate of 11 percent from 1965 to 1985; U.S. total industrial R\&D increased at a rate of 3 percent and company-funded R\&D at a rate of 5 percent for the same period. Consequently, Japanese industrial R\&D expenditures increased from less than onetenth of the U.S. level in 1965 to one-third of the total U.S. level and one-half of the company-funded level in 1985. Japanese industrial $R \& D$ expenditures were constant $\$ 24.4$ billion in 1986; total U.S. expenditures were constant $\$ 73.3$ billion with company-funded R\&D expenditures of constant $\$ 47.9$ billion. (See p. 18.)

- As a percentage of GNP, Japanese industrial R\&D more than doubled from 1965 to 1986. In 1986, this ratio was comparable to that of the United States: 1.9 percent and 2.0 percent, respectively. Since Japanese industrial R\&D is almost entirely (98 percent) financed by companies themselves, Japanese company-funded R\&D as a percentage of GNP has surpassed the U.S. ratio every year since 1970 . In 1985 and 1986, the ratio of company-funded R\&D to GNP was 1.9 percent for Japan and 1.3 percent for the United States. (See p. 18.)

- Electrical machinery, chemicals, general machinery, and the motor vehicles industries are the four largest performers of manufacturing R\&D in Japan. These industrial sectors together accounted for 68 percent of manufacturing R\&D in 1965 and 73 percent in 1985. The United States has a slightly different set of the largest company-funded R\&D performers of manufacturing R\&D (electrical machinery, chemicals, motor vehicles, and professional and scientific instruments); they accounted for 70 percent of manufacturing R\&D in 1985. (See p. 19.)
- The ratio of R\&D to net sales for all Japanese manufacturing industries in 1985 was 2.7 percent, compared to 2.8 percent for company-funded $R \& D$ in the United States. The ratios for the two countries were similar for many manufacturing industries. Drugs and medicines, communications and electronic equipment, and professional and scientific instruments were the most R\&D-intensive industries in both countries. (See p. 20.)

- R\&D is slightly less concentrated in Japan than in the United States. In 1985, the top five Japanese R\&D firms accounted for 18 percent of total manufacturing $R \& D$, compared to 23 percent for the top five U.S. firms. For most manufacturing industries, the levels of industrial R\&D concentration are lower in Japan than in the United States; an appreciably higher level of Japanese industrial R\&D dominance is found only in the iron and steel industry. (See p. 20.)

- During the past 2 decades, the number of Japanese industrial R\&D scientists and engineers has increased at an average annual rate of 7.1 percent; in the United States, this increase was 2.5 percent. By 1985 Japan employed 231,000 scientists and engineers engaged in industrial R\&D, two-fifths as many as the U.S. 570,000 full-time equivalent. (See p. 21.)

- Although Japan has a lower absolute number of industrial scientists and engineers, its ratio of manufacturing $R \& D$ scientists and engineers per 10,000 employees is higher than that of the U.S. (which uses full-time equivalent scientists and engineers). The Japanese ratio in 1985 was 470 , compared to 400 for the United States. (See p. 21.)

\section{higher education}

- In contrast to the U.S. system of relying principally on separately budgeted R\&D project awards, Japan depends principally on a system of institutional funding in which universities and colleges receive general university funds (GUF) from the national Government for teaching, research, and facilities and equipment. Three-quarters of all Japanese higher education R\&D funds are received through such general funds, whereas an estimated three-quarters of U.S. higher education R\&D funds are obtained from specifically budgeted project items. (See p. 24.)

- Nearly 31 percent of Japan's natural scientists and engineers engaged in R\&D in 1985 were in higher education ( 60 percent of these were in health-related fields), compared with 14 percent of such personnel in the United States. As a share of total R\&D, higher education R\&D expenditures account for 20 percent in Japan and 12 percent in the United States. Both in Japan and the United States, however, the higher ed- 
ucation sectors conduct comparable shares of national basic research efforts (55-56 percent). (See p. 24.)

- $R \& D$ expenditures in the Japanese higher education sector more than tripled in constant terms from 1965 to 1985 . These expenditures increased at an average annual rate of 6.1 percent, compared with 3.2 percent in the United States. In 1986, R\&D expenditures in Japanese higher education totaled constant $\$ 7.3$ billion, compared with constant $\$ 12.7$ billion in the United States. (See p. 24.)

- For separately budgeted higher education R\&D funds, the funds distribution among fields is significantly different in Japan than in the United States. The highest concentration of Japanese separately budgeted funds is in the physical sciences ( 36 percent compared to 12 percent in the United States); in the United States, the concentration is in the life sciences (54 percent compared to 26 percent in Japan). Japan spends about 20 percent of its separately budgeted R\&D in engineering, compared to 14 percent in the United States. (See pp. 26-27.)

- The Japanese ratio of all first university degrees as a proportion of the 22-year-old population was 22.6 percent in 1985. This proportion was 25.3 percent in the United States. Although the United States confers a much higher total number of doctorates than does Japan, the overall ratio is similar in both countries (0.50.7 percent) when the number of doctoral degrees is measured as a proportion of the 27 -year-old age group. (See p. 27.)

- While the Japanese higher education system annually graduates about the same number of engineers as the United States, it graduates only about one-tenth as many first-degree students in the natural sciences. The distribution of Japanese first university degrees among fields is dissimilar from that in the United States: there is relatively less emphasis on the natural sciences ( 3 percent and 11 percent, respectively) and relatively more on engineering ( 19 percent and 7 percent, respectively). (See pp. 27-28.)

\section{outputs and impacts}

- According to the Science Citation Index, Japanese researchers increased their share of the world's S/T articles from 5.1 percent in 1973 to 7.6 percent in 1984. Japan's shares of publications are largest in the fields of chemistry, engineering, and physics; they are lowest in the earth and space sciences. (See p. 32.)

- The Japanese share of S/T articles during the 1973-82 period was greatest in the pharmacy subfield, with Japanese publications accounting for 25 percent of the articles written in that subfield. The next largest shares were in polymers (18 percent) and marine biology and hydrobiology (14 percent). (See p. 32.)

- Japan accounts for the largest share of foreign-origin patents in the U.S. patent system. From 1970 to 1986, the share of U.S. patents annually granted to the Japanese increased from 4 percent to 19 percent. As a share of Standard Industrial Classification (SIC) product fields, Japanese patent shares are highest in the office computing machinery, aircraft and parts, and communications equipment and electronic components product groups. (See p. 33.)

- Given their total representation in the U.S. patent system, Japanese patents account for 45 percent more of the top 1 percent most highly cited U.S. patents than expected. The highest citation rates for Japanese patents are in the automotive, semiconductor electronics, photocopying and photography, and pharmaceuticals patent classes. (See p. 34.)

- Japan has made rapid progress in manufacturing productivity during the past decade; its manufacturing output per worker-hour increased 68 percent from 1977 to 1986 , compared with a 26-percent increase in the United States for the same period. (See p. 34.)

- Japan's technological balance of payments worsened in dollar terms from a deficit of constant $\$ 1.2$ billion in 1970 to constant $\$ 1.7$ billion in 1985; however, receipts increased threefold from constant \$194 million to constant $\$ 721$ million. In 1985, 42 percent of Japanese sales and 99 percent of technical know-how purchases were with the United States and Europe; East Asian nations accounted for about 40 percent of Japanese technical know-how sales. (See p. 35.)

- For several manufacturing industries (textiles, chemicals, iron and steel, and motor vehicles), Japan's technical know-how receipt to payment ratio exceeded 100 percent in 1985. For the iron and steel industry, receipts for Japanese technical know-how exceed Japanese payments by almost 6 to 1 . In no industry other than ceramics did Japanese purchases of technical know-how exceed 8 percent of the respective industry's R\&D expenditures; in most industries, it was 5 percent or less. (See p. 36.)

- Japanese technology-intensive trade with the United States has markedly improved over the $1965-85$ period. The Japanese trade surplus with the United States in technology-intensive goods increased from current \$143 million in 1965 to current \$13 billion in 1985 . Large trade surpluses existed in 1985 in radio and television receiving equipment, communications equipment, office and computing machines, and professional and scientific instruments; however, Japan had a negative trade balance in aircraft and parts, industrial inorganic chemicals, agricultural chemicals, and drugs. Japan similarly has increased its world share of technology-intensive trade from 7 percent in 
1965 to 19 percent in 1985; during the same period, the U.S. share declined from 28 percent to 24 percent. (See pp. 36-38.)

- The U.S. deficit with Japan in high-technology (a slightly different definition than technology-intensive) trade grew fivefold from 1980 to 1986, increasing from current $\$ 3.8$ billion to current $\$ 21.9$ billion. Telecommunications equipment and electronic components accounted for about 75 percent of the high-technology trade deficit. (See p. 37.) 



\section{national r\&d patterns}

\section{total $r \& d$ expenditures}

Over the past 2 decades, Japan has substantially increased its investments in R\&D. Starting at a relatively small base, $R \& D$ expenditures in Japan increased nearly fivefold between 1965 and 1985, growing from constant (1982) $\$ 6.1$ billion to $\$ 36.0$ billion-an average annual rate of increase of 9.3 percent (chart 1). During the same period, U.S. investments in R\&D rose 63 percent, from constant $\$ 59.4$ billion to $\$ 96.5$ billion, increasing at an average annual rate of 2.5 percent. In constant terms, U.S. R\&D expenditures experienced virtually no net growth between 1965 and 1975, while Japanese expenditures during the period more than doubled. U.S expenditures increased from 1965 to 1968 , but declined during most of the $1968-75$ period. By 1975, U.S. R\&D spending was just barely above its 1965 total. Although U.S. expenditures increased by 61 percent from 1975 to 1985 , this gain represents only slightly more than onehalf of the Japanese increase of 116 percent for the period. During 1980-
86, U.S. R\&D expenditures increased 37 percent; Japanese R\&D expenditures increased 58 percent.

Although U.S. investments in R\&D are nearly three times as high as those of Japan in absolute terms, Japan's investment is now comparable based on the size of its economy. The Japanese R\&D to GNP ratio rose consistently during the past 2 decades,
Chart 1. National R\&D expenditures [Constant 1982 doflars]

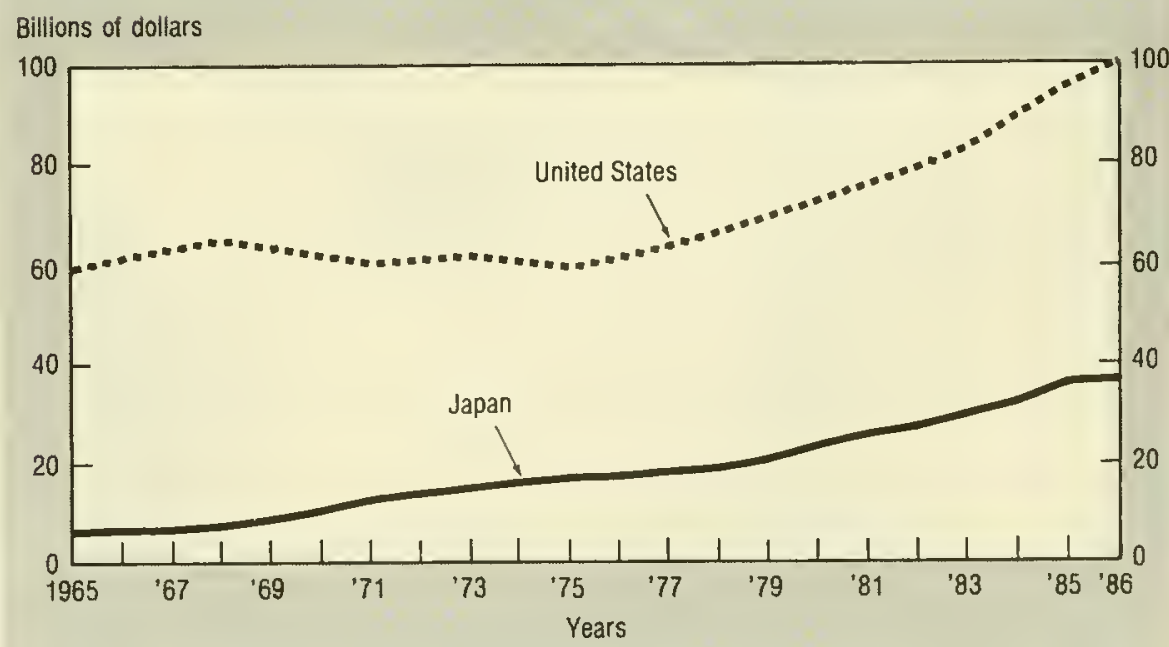

SOURCE: National Science Foundation, SRS, table B-1 
reaching a level of 2.8 percent in 1985 and 1986 (chart 2). ${ }^{2}$ In contrast, the U.S. ratio, which was 2.8 percent in 1965 , steadily declined to a low of 2.1 percent in 1978; by 1985, it had again risen to 2.7 percent. crease in Japanese $R \& D$ expenditures outpaced the growth of the Japanese economy: Japan's average annual rate of increase in $R \& D$ was 9.3 percent; its GNP growth was 6.0 percent. In the United States, R\&D efforts expanded at a slightly slower rate than did GNP -2.5 percent and 2.8 percent, respectively.

Less than 1 percent of Japanese R\&D expenditures was devoted to defense purposes in 1985; this is a significant contrast to the 30 -percent figure in the United States. Consequently, Japan has a higher ratio of nondefense $R \& D$ expenditures to GNP (2.8 percent) than does the United States (1.9 percent). Japan has maintained a lead in this indicator since at least 1971 (chart 3). In ab-

2Japanese reports often give a different ratio because they use only natural science and engineering $R \& D$ and/or national income instead of GNP.
Between 1965 and 1985, the in-

\section{Chart 3. Nondefense R\&D/GNP ratios}

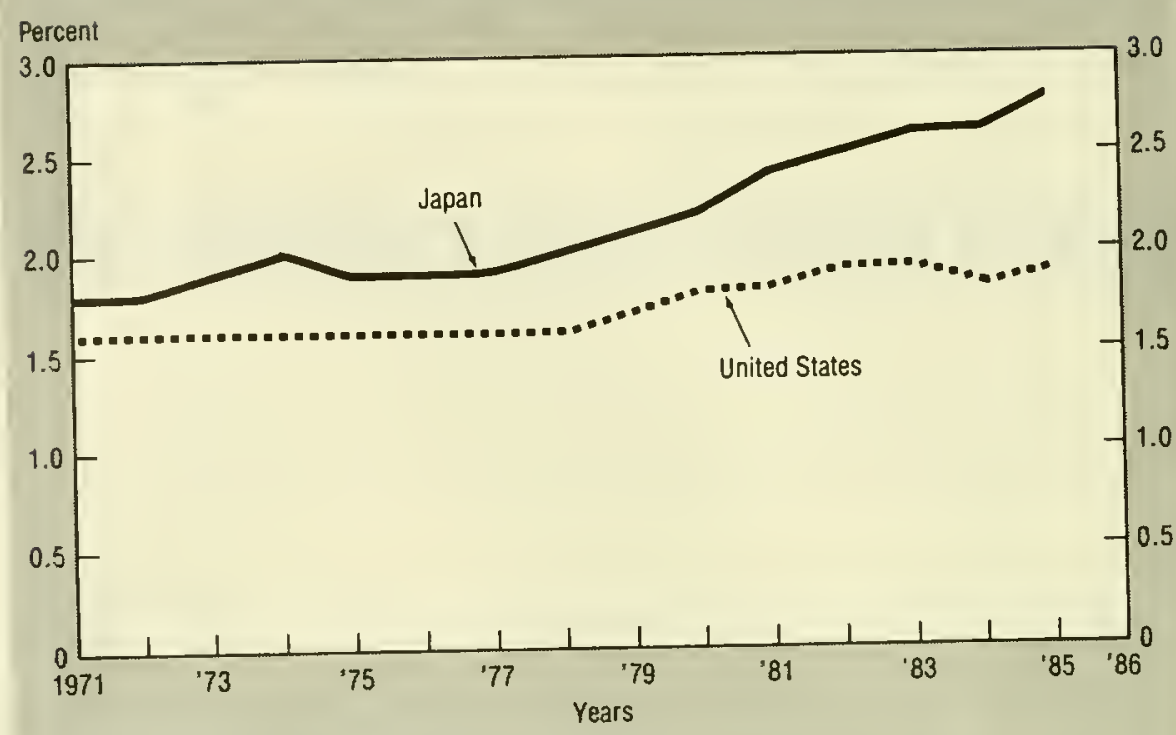

SOURCE: National Science Foundation, SAS, table B-3

solute terms, Japan's nondefense $R \& D$ expenditures were one-half of U.S. nondefense R\&D expenditures in 1985.

\section{Chart 2. Total R\&D/GNP ratios}

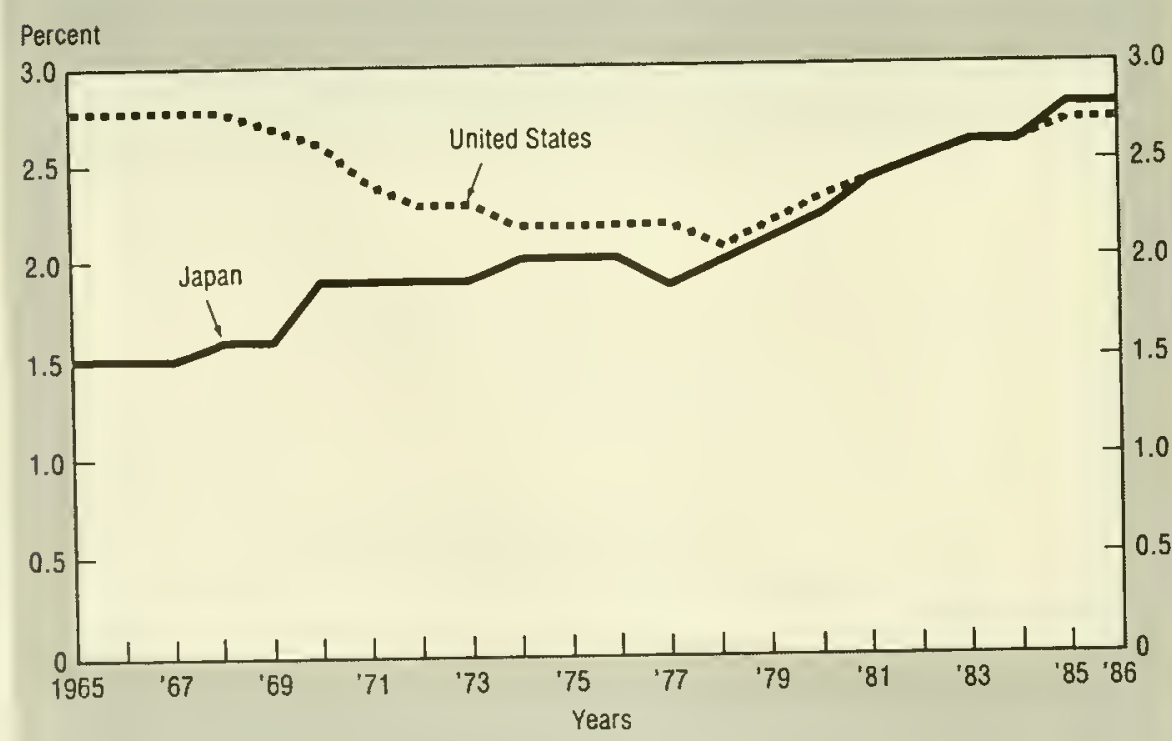

SOURCE. Nationa: Science Foundation, SAS. table B-2

\section{r\&d expenditures by source and performer}

The Japanese Government's funding of R\&D is substantially less than that of industry, and-although steadily increasing-it has not kept pace with the growth in industrially funded R\&D. From 1970 to 1985 , government $R \& D$ funding increased at an average annual rate of 5 percent while industrial funding increased at a rate of 9 percent. Also, in 1970, the government supported 29 percent of all R\&D, but by 1985 its share had decreased to 21 percent (chart 4). This decline is attributable both to Japan's strict deficit reduction policy and to the growing relative share of industrial $R \& D$ funding. Nevertheless, the government allowed a higher growth rate for $R \& D$ support than for many other program areas.

Compared with the United States, the Japanese Government supports a smaller proportion of national R\&D 
Chart 4. National R\&D funding by source

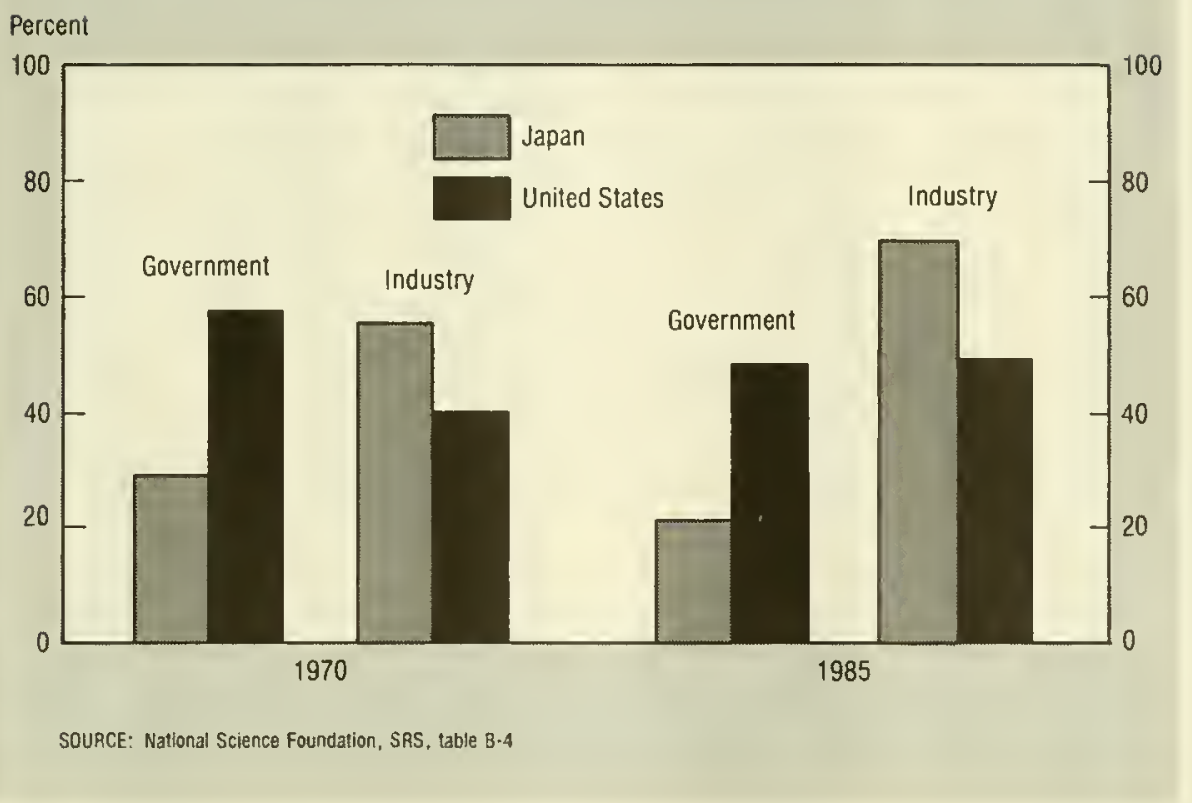

expenditures while Japanese industry supports a greater share (chart 5). In 1985, the U.S. Government funded 48 percent of R\&D; the Japanese Government funded 21 percent. Much of this difference in
Japanese-U.S. Government shares of total funding derives from the U.S. Government's strong support of defense-related R\&D. On the other hand, Japanese industries provide a relatively larger share of national
R\&D funding - in 1985, Japanese industry funded 69 percent of total $R \& D$ compared to the U.S. industry share of 49 percent.

Although there are major differences in the primary sources of $R \& D$

Chart 5. National R\&D funding by source: 1985

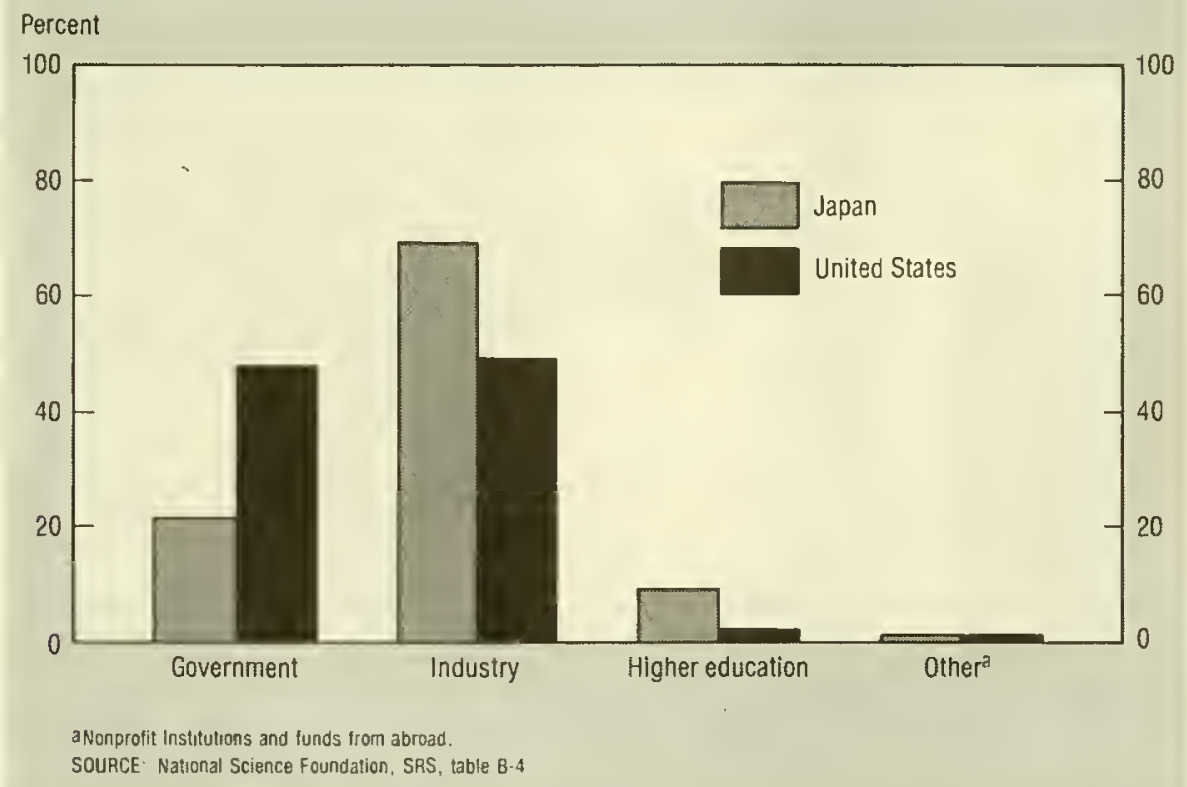


funding in Japan and the United States, both countries exhibit similar patterns of R\&D by performer. In 1985 , industry expended the majority of R\&D funds (67 percent for Japanese industry and 73 percent for U.S.), higher education accounted for the second largest share of R\&D expenditures, and government accounted for nearly all of the remainder (chart 6). In terms of the flow of R\&D funds from source to performer, there is a higher level of funds transfer among sectors in the United States than in Japan, especially from government to industry. In Japan, the flow from government to higher education is greater. ${ }^{3}$

3Japan and most European countries include in R\&D a category of expenditures called "general university funds" (GUF), which are nationally allocated funds for the general operating expenses of colleges and universities. The United States has no equiv. alent to GUF, since nearly all nationally allocated R\&D monies are "separately budgeted R\&D." Thus, the larger Japanese flow from government to higher education is mainly due to the component of general university funds in government expenditure statistics. U.S. State Governments support more than one-half of all American universities, but virtually none of the general operating expenses of these State universities are included in U.S. R\&D expenditures. (For a more detailed discussion of these differences, see appendix A.)

\section{r\&d by character of work}

While conceptual distinctions can be established between basic and applied research and between R\&D, there are obvious difficulties in measuring and assigning specific $R \& D$ activities to the respective categories. These difficulties are increased when making international comparisons of absolute levels of R\&D by character of work. Therefore, greater stress should be placed on evaluating trends within each country over time. ${ }^{4}$

By 1985, the overall distribution of total R\&D funds within the two countries by character of work was very similar, although it appears that the share of Japanese R\&D devoted to basic research has declined somewhat over the past 10 years. In 1975 and 1980 basic research accounted for 15 percent of $R \& D$ expenditures;

For a discussion of differences in U.S. and Japanese definitions and treatments of basic research, see appendix $\mathrm{A}$
Chart 6. National R\&D expenditures by performer: 1985

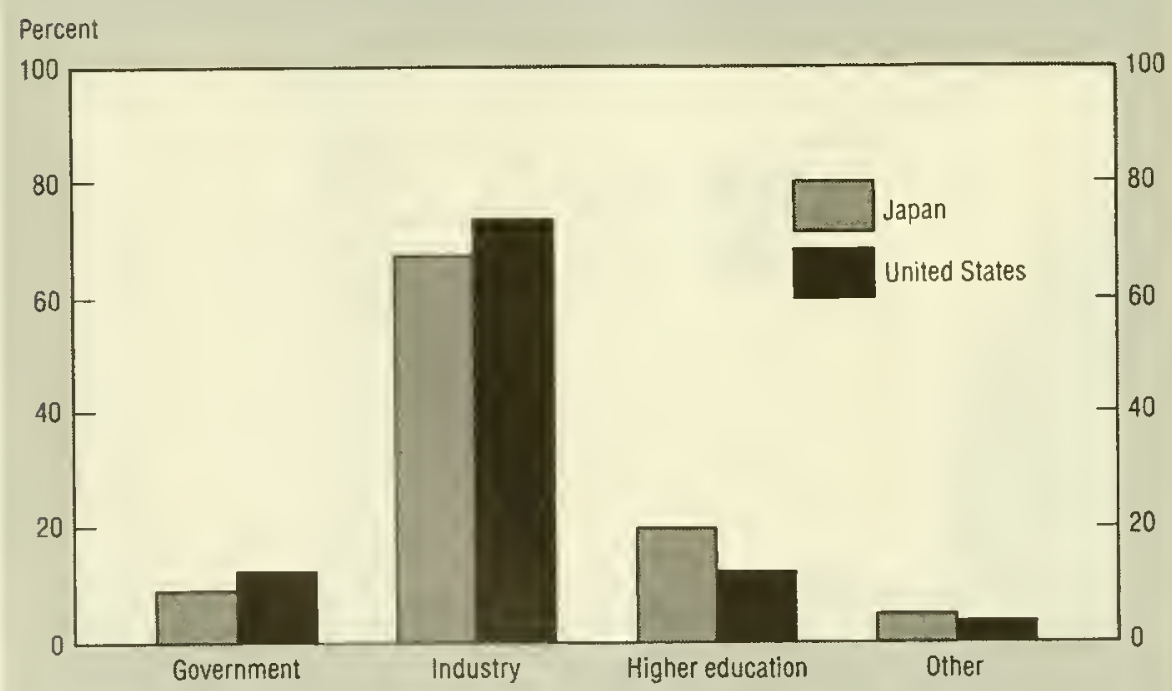

SOURCE: Natıonal Science Foundation, SRS, table 8.5 by 1985 , however, this share had declined slightly to 13 percent (table B6). ${ }^{5}$ In the United States, basic research as a share of total R\&D remained constant during 1975-85 at 12-13 percent. In 1985, Japan devoted a marginally higher proportion of R\&D to applied research than did the United States ( 25 percent and 22 percent, respectively); in contrast, the United States devoted relatively more expenditures to development-66 percent and 62 percent, respectively (charts 7 and 8 ). This difference largely reflects the greater U.S. defense R\&D effort, which is primarily development.

The distribution of R\&D by character of work among performing sectors is also very similar for the two countries, with higher education placing nearly equal emphasis on basic research (56-58 percent) and industry placing similar emphases on basic research (4-6 percent), applied research (20-22 percent), and development (72-76 percent).

For the past several years, Japanese research leaders-including the Prime Minister's Council for Science and Technology - have urged an increased emphasis on "fundamental research." (The combination of basic

\footnotetext{
${ }^{5}$ Because of changes in the methodology of the key Japanese national R\&D survey, it is not possible to calculate basic research from these data prior to Japan fiscal year 1974. However, in the Science and Technology Agency's White Paper on Science and Technology, 1983 (Tokyo, Japan, 1983), it was estimated that basic research was 28 percent of R\&D expenditures in 1967.

This relatuve decline in basic research expenditures in Japan has occurred exclusively in the higher education sector. Here, basic research declined from 72 percent in 1975 to 56 percent in 1985; in turn, the share of applied research mcreased by the same magnitude, rising from 20 percent to 36 percent. However, real higher education expenditures on basic research doubled during this period, indicating that the relative decline is principally the result of a higher rate of growth in applied research expenditures. It is also possible that, over time, Japanese researchers view the distinction between basic and applied research in a manner more similar to U.S. perceptions. (See appendix A.) This would imply that the relative decline of basic research (and the concommitant increase in applied research) is also a function of a reclassitication of research activity, rather than simply a reflection of a shift in research focus.
} 
Chart 7. Japanese R\&D by performer and character of work: 1985

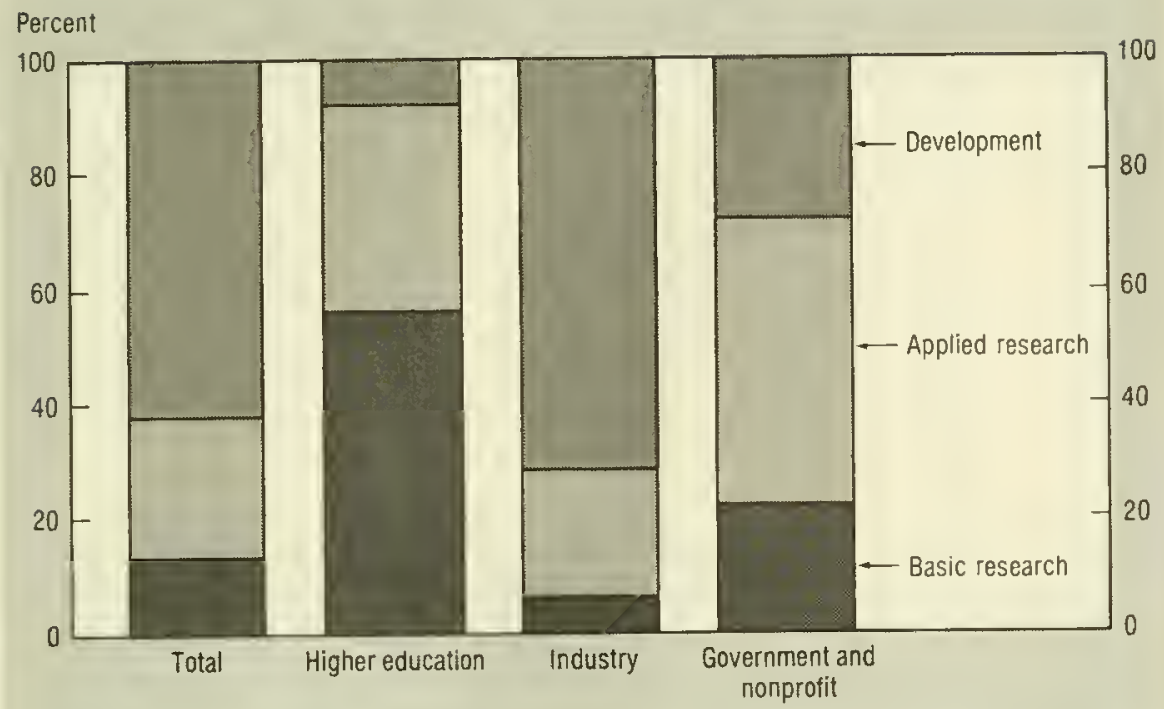

SOURCE: National Science Foundation. SRS, table 8-6 and applied research is sometimes called "fundamental research" in Japan to distinguish research from development.) Funds supporting this effort have come from industrial R\&D initiatives because of the recent fis- cal restraint of the Japanese Government. Between 1980 and 1985, the proportion of Japan's industrial R\&D funds devoted to basic and applied research combined increased from 25 percent to 28 percent.
Chart 8. U.S R\&D by performer and character of work: 1985

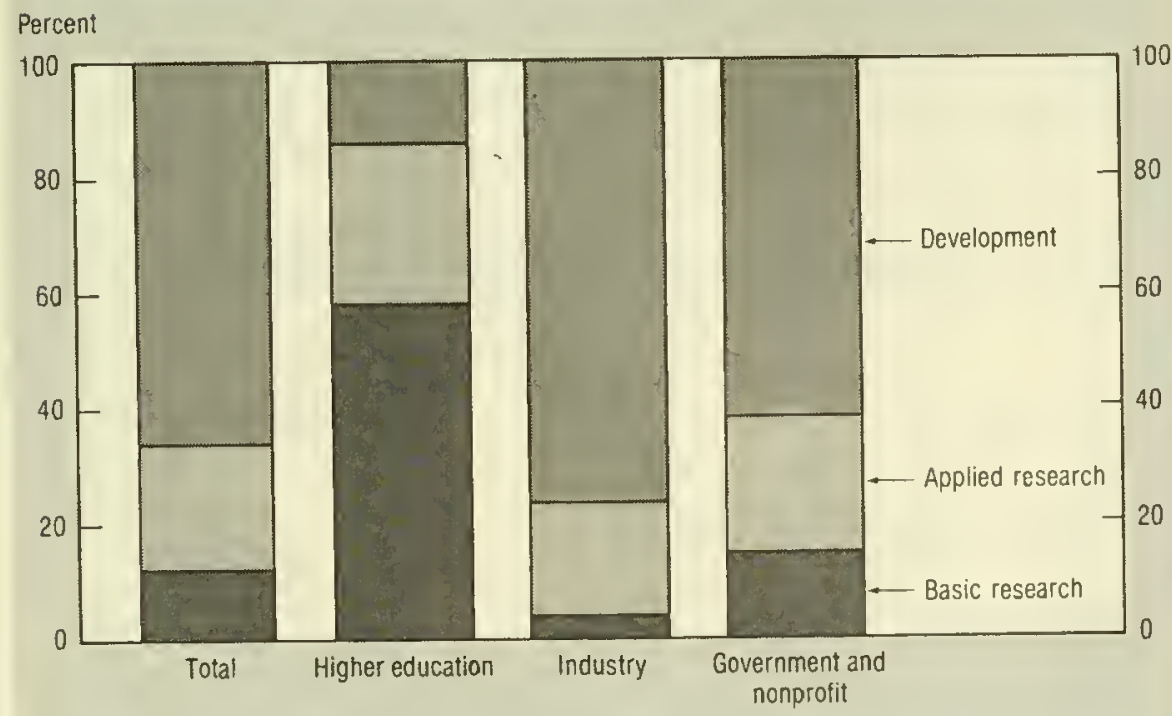

SOURCE. National Sclence Foundation, SAS, table B-6

\section{scientists and engineers}

Stock of scientists and engineers. Given their central role in the R\&D process, the number of scientists and engineers in a country provides a good indication of that country's S/E capability. The stock of scientists and engineers represents the total number of people in a country who are qualified to be scientists and engineers, regardless of their employment status. International data on scientist and engineer stock are difficult to obtain, however, because most countries do not account for those scientists and engineers who are unemployed or employed in fields other than science and engineering. Employment data derived from national censuses are the best source of information on the stock employed in S/E capacities, with the understanding that these data understate the total stock of scientists and engineers because of the above factors.

Japan had slightly more than 1.5 million employed nonacademic scientists and engineers in 1985, compared with almost 3.6 million in the United States in 1986 (table 1). Japan has fewer nonacademic scientists and engineers relative to its labor force than does the United States. This condition is attributable to the lower absolute and relative levels of scientists in Japan than in the United States: Japan had 28 percent as many scientists and one-half as many engineers in 1985 as the United States had in 1986, even though the Japanese labor force is slightly more than one-half that of the United States. ${ }^{6}$

\footnotetext{
Including social scientists and scientific personnel Data are trom Peter O. Way and Ellen Jamison, Charactersistcs of Screntific and Techmcal Manpower in the Unted States and Four Other Industralized Coun tries (IVashington, D.C. : U.S. Bureau of the Census, 1986); U.S. Bureau of the Census, Center for International Research, Recent Data on Stientists and Engineers m Industrialized Countries (Washington, D.C. February 1988); and the National Science Foundation.
} 
Table 1. Stock of scientists and engineers: ${ }^{1} 1980$ and 1985 or 1986

\begin{tabular}{|c|c|c|c|c|}
\hline \multirow[b]{2}{*}{ Scientists and engineers } & \multicolumn{2}{|c|}{ Japan } & \multicolumn{2}{|c|}{ United States } \\
\hline & 1980 & 1985 & 1980 & 1986 \\
\hline $\begin{array}{l}\text { Scientists and engineers, total } \ldots \ldots \ldots \ldots \ldots \\
\quad \text { Per } 10,000 \text { labor force } \ldots \ldots \ldots \ldots \ldots \ldots\end{array}$ & $\begin{array}{r}940,301 \\
164\end{array}$ & $\begin{array}{r}1,514,200 \\
251\end{array}$ & $\begin{array}{r}2,369,200 \\
218\end{array}$ & $\begin{array}{r}3,583,300 \\
300\end{array}$ \\
\hline $\begin{array}{l}\text { Engineers } \ldots \ldots \ldots \ldots \ldots \ldots \ldots \ldots \ldots \ldots \ldots \\
\quad \text { Per } 10,000 \text { labor force } \ldots \ldots \ldots \ldots \ldots \ldots\end{array}$ & $\begin{array}{r}744,380 \\
130\end{array}$ & $\begin{array}{r}1,124,300 \\
187\end{array}$ & $\begin{array}{r}1,486,400 \\
137\end{array}$ & $\begin{array}{r}2,190,400 \\
183\end{array}$ \\
\hline $\begin{array}{l}\text { Civil } \ldots \ldots \ldots \ldots \ldots \ldots \\
\text { Electrical/electronic } \ldots \ldots \ldots \ldots \ldots \ldots \ldots \\
\text { Industrial and mechanical } \ldots \ldots \ldots \ldots \ldots \ldots\end{array}$ & $\begin{array}{l}351,929 \\
119,499 \\
272,952\end{array}$ & $\begin{array}{l}485,400 \\
233,100 \\
405,800\end{array}$ & $\begin{array}{l}214,300 \\
351,600 \\
920,500\end{array}$ & $\begin{array}{r}313,100 \\
528,100 \\
1,349,200\end{array}$ \\
\hline $\begin{array}{l}\text { Scientists } \ldots \ldots \ldots \ldots \ldots \ldots \\
\quad \text { Per } 10,000 \text { labor force } \ldots \ldots \ldots\end{array}$ & $\begin{array}{r}195,921 \\
34\end{array}$ & $\begin{array}{r}389,900 \\
65\end{array}$ & $\begin{array}{r}882,800 \\
81\end{array}$ & $\begin{array}{r}1,393,000 \\
117\end{array}$ \\
\hline $\begin{array}{l}\text { Natural ... } \\
\text { Computer } \\
\text { Social .... }\end{array}$ & $\begin{array}{r}63,729 \\
129,764 \\
2,428\end{array}$ & $\begin{array}{r}67,100 \\
320,500 \\
2,300\end{array}$ & $\begin{array}{l}471,400 \\
192,100 \\
219,400\end{array}$ & $\begin{array}{l}652,300 \\
420,900 \\
319,800\end{array}$ \\
\hline
\end{tabular}

'Nonacademic scientists and engineers employed as scientisis and engineers. See text footnote 7 ( 6 ) for an explanation of why acadernics are excluded

NOTE 8 ecause of rounding. figures may not add to totals shown.

SOURCES: Peter 0 Way and Ellen Jamison, Characteristics of Scientific and Technical Manpower in the Umied States and Four Other Industrialized Countries (Washington. O C. U S Bureau of the Census, 1986). U.S Bureau ot the Census. Center for International Research, "Recent Oata on Scientists and Engineers in Industrialized Countsies" (Washıngton, D C. February 1988); U.S. Bureau of Labor Statıstics, and the National Science Foundation

Comparative data for engineers indicate higher relative levels of engineers per 10,000 labor force in Japan: in 1985, there were 187 engineers per 10,000 labor force compared with 183 in the United States in 1986. Japan had 65 scientists per 10,000 labor force compared with 117 in the United States.

Both countries have experienced significant increases in the stock of nonacademic scientists and engineers relative to overall labor force increases. The Japanese stock of scientists and engineers grew 61 percent from 1980 to 1985; during this period, the total labor force grew by only 5 percent. Concurrently, the number of scientists doubled, largely because of a 147-percent increase in the number of computer specialists (the proportion of natural scientists per 10,000 labor force remained constant from 1980 to 1985). Also, the number of engineers increased by 50 percent, with the stock of electrical/ electronic engineers nearly dou- bling. The U.S. experience was similar: increases of nearly 50 percent or more were registered in most categories of scientists and engineers, with the largest growth (119 percent) occurring in the stock of computer specialists. In contrast, the U.S. labor force increased only 10 percent from 1980 to 1986.

R\&D scientists and engineers. Distinct from the total stock of scientists and engineers is the number who are currently active in R\&D. ${ }^{7}$ Japanese and U.S. surveys on the

'Unlike data on the stock of scientists and engineers, which exclude academics, data on scientists and engineers engaged in $R \& D$ include acadenic scientists and engineers. Stock data are derived from the occupational categories of national censuses, which do not distinguish academics by discipline. Consequently, it is not possible to calculate only that faculty in science and engineering from the census data On the other hand, the numbers of scientists and engineers engaged in $R \& D$ are obtained from R\&D surveys that do distinguish personnel by discipline. number of scientists and er. engaged in $R \& D$ are not strictly comparable, because Japanese surveys ask for the total number of scientists and engineers engaged in $R \& D$ regardless of the amount of time devoted to R\&D activities. U.S. surveys, on the other hand, ask for adjustments to estimate full-time equivalence. In order to adjust the Japanese data, information here excludes data on the social sciences and humanities and uses only data on the natural sciences and engineering. ${ }^{8}$

Regardless of these differences, there can be no dispute concerning the rapid increase of Japan's S/E labor force. The total number of Japanese $R \& D$ scientists and engineers engaged in $R \& D$ has tripled since 1965, and in 1986 was 405,600-onehalf of the U.S. full-time-equivalent total of 802,300 . Japan's scientists and engineers are also much younger than their U.S. counterparts: in 1985, almost one-half of Japanese nonacademic scientists and engineers were under 35 years old, compared with 28 percent in the United States. The ratio of Japanese $R \& D$ scientists and engineers per 10,000 labor force was about one-third the U.S. ratio in 1965; in 1986, however, the two ratios were comparable at 69 percent and 67 percent, respectively (chart 9). Within the R\&D-performing sectors, Japan has a slightly larger absolute number of scientists and engineers in the higher education sector than the U.S. full-time equivalent; however, the United States has 2.5 times as many industrial scientists and engineers engaged in $R \& D$ as does Japan and nearly three times as many in government and nonprofit settings (chart 10).

\footnotetext{
${ }^{8}$ By excluding social scientists from the Japanese S/E data, it is possible to get a closer estimate of those full-time scientists and engineers actually conducting R\&D. For a more detailed discussion of this adjustment, see appendix $A$
} 
Chart 9. Sclentists and engineers engaged in R\&D per 10,000 labor force ${ }^{a}$

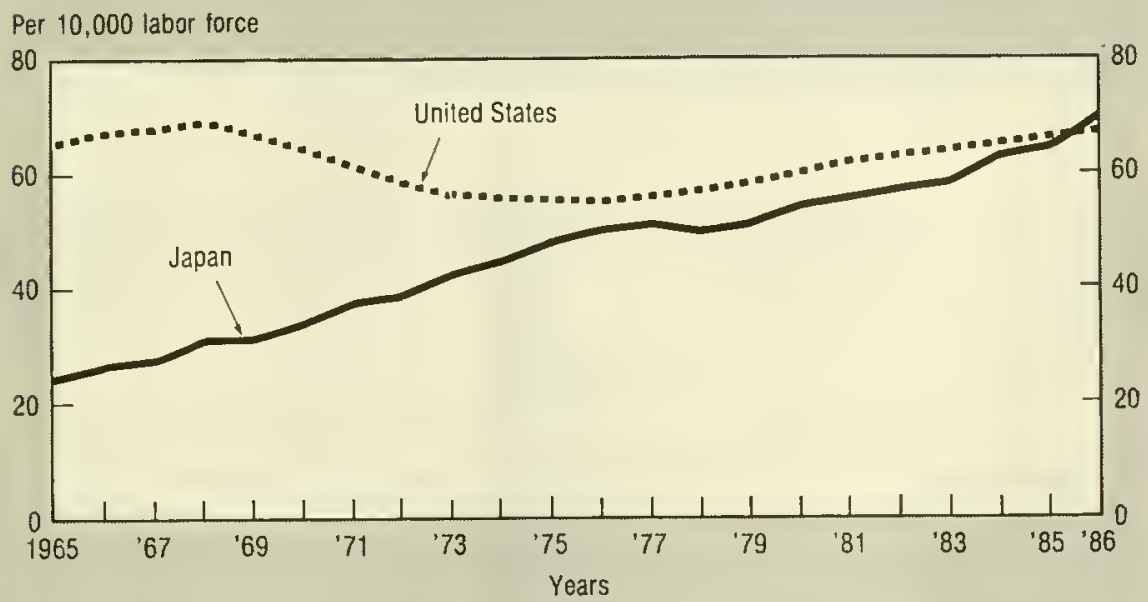

aU.S. figures are full-time equivalents, whule Japanese are totat numbers of screntists and engineers engaged in R\&O. SOURCE National Science Foundation, SRS. table B-7

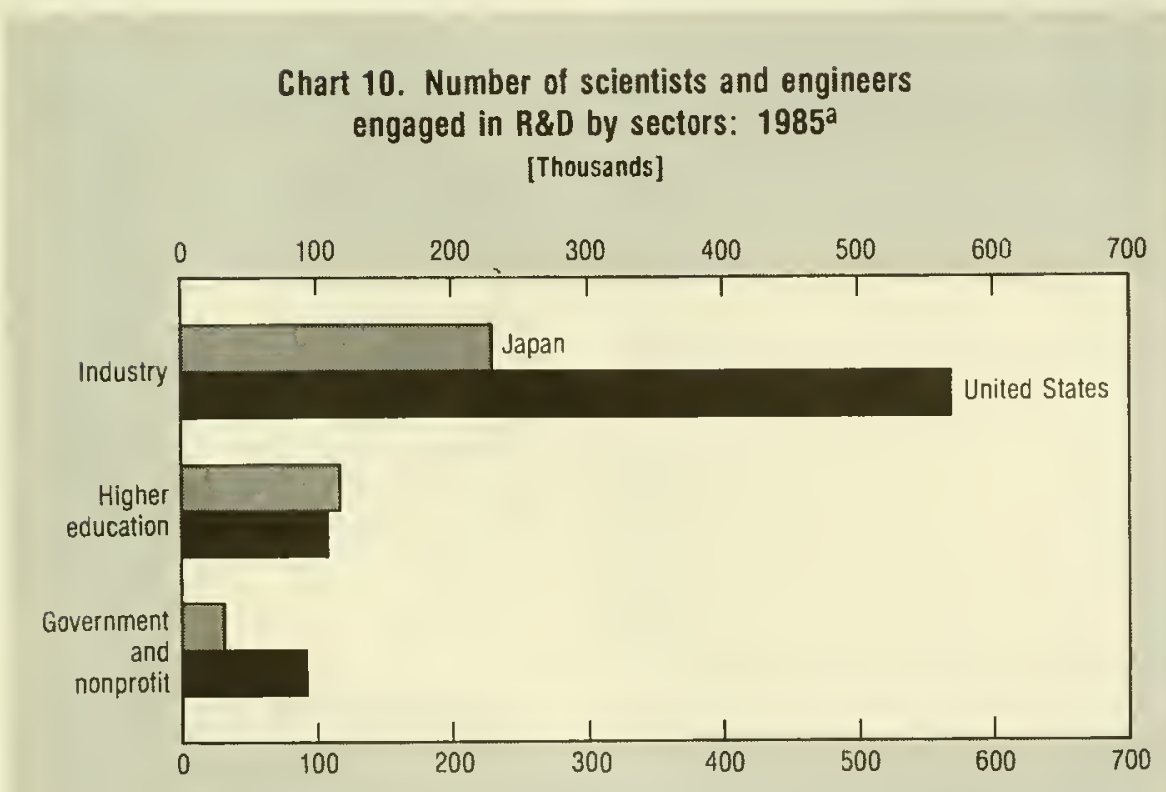

aU S figures are full-ume equivalents, while Japanese are total mumbers of scientists and engineers engaged in R\&O. SOURCE. Nationa! Science Foundation, SRS, table B-8

\section{technical know-how expenditures and receipts}

Although receipts for and expenditures on technical know-how (royalties and fees) typically are viewed as $S / T$ outputs, Japan historically has used licensed technology to supplement its own R\&D efforts. Consequently, Japanese trends regarding royalties and fees are discussed here as an integral part of the country's R\&D efforts (they are discussed again in chapter 5 on S/T outputs and impacts).

In 1970, Japan spent constant $\$ 1.4$ billion on royalties, licensing fees, and other expenses related to imported technology. These expenditures were 57 percent of what the United States spent in the same year for technical know-how (chart 11). Japan's expenditures for technical know-how in 1970 were 11 percent of total national R\&D expenditures, compared to 4 percent in the United States. ${ }^{9}$

Japan has continued to spend a substantial amount on technical know-how. ${ }^{10}$ Between 1970 and 1985 ,

\footnotetext{
${ }^{9}$ These lapanese royalties and fees data are from the Bank of Japan, which are most comparable to U.S. data because they include transactions for film rights, book royalties, and other cultural items. The Japanese Statistics Bureau also provides technical know-how data, but on manufacturing industres only. These latter data are presented in chapter 5 , "Outputs and Impacts," and the differences between the two data series are discussed in footnote 43 of that chapter

${ }^{10}$ Increases in the dollar amount of technical knowhow purchases cannot be equated on a one-to-one hasis with increases in the actual volume of technology transfer. Because of uncertainties about the market valuation of technology, it is possible that increasing expenditures on technical know-how reflect purchases of less, but more expensive, technology.
} 
Chart 11. Value of technical know-how expenditures and receipts

[Constant 1982 dollars]

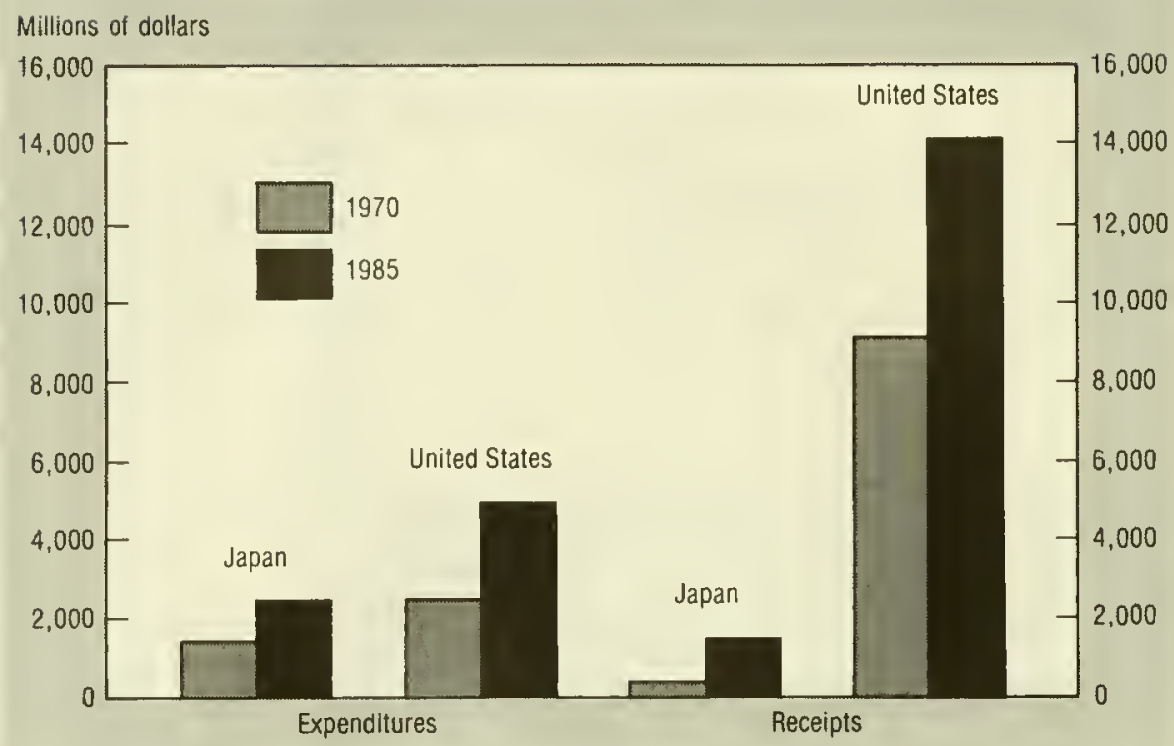

SOURCE: National Science Foundation, SRS, table B-9

its payments for royalties and fees increased by 71 percent; this was not quite as large as the increase for $R \& D$, which nearly tripled. Consequently, the share of Japanese payments for technical know-how to R\&D decreased to 7 percent in 1985.
In 1970, Japan exported constant \$194 million worth of technical knowhow; in the same year, the United States had exports of constant $\$ 8.6$ billion. Since 1970, Japanese technology has been in greater demand by overseas customers and the Jap- anese have been more willing to sell their technology; by 1985, Japan was exporting constant $\$ 721$ million worth of technical know-how, improving the share of receipts to payments from 14 percent in 1970 to 30 percent in 1985. 


\section{chapter 2.}

\section{government r\&d}

The Japanese Government's share of total national R\&D funding reached its peak in 1972 at 33 percent. It has declined fairly steadily since then to its 1985 level of 21 percent. In comparison, the U.S. Government's share of national $R \& D$ funding is much higher, although it also declined from 1970 to 1985 , dropping from 57 percent to 48 percent.

Despite its declining relative contribution to total national $R \& D$ resources, the actual value of Japanese Government funds has steadily increased, reaching constant $\$ 7.6$ billion in 1985. U.S. Federal fundingwhich declined during 1970-75, but has increased steadily since thenwas constant $\$ 46.0$ billion in 1985 (chart 12). Despite an environment of fiscal restraint, the Japanese Government's S/T budget has received a high priority in the last 5 years. From 1980 to 1985, Japanese Government $R \& D$ funding increased at an average annual rate of 3 percent (a net increase of 16 percent) compared with a 6-percent average annual rate (a net increase of 33 percent) in the United States. In the United States, 90 percent of the growth in government R\&D funding is accounted for by increases in defenserelated $R \& D$.

\section{organization of $\mathbf{s} / \mathbf{t}$ policymaking}

In spite of its relatively small share of total national R\&D funding, the
Japanese Government plays an important role in science and technology both by identifying new directions for national $R \& D$ efforts and by indicating $R \& D$ initiatives to industry through a program of financial incentives and selective funding of particular $R \& D$ projects. Chart 13 presents the governmental structure of $\mathrm{S} / \mathrm{T}$ administration in Japan.

$\mathrm{S} / \mathrm{T}$ policy in Japan is largely the responsibility of four institutions: the Prime Minister's Council for Science and Technology; STA; the Ministry of Education, Science, and Culture (Monbusho); and MITI. ${ }^{11}$ In one capacity or another, these four organizations: (1) develop national S/T policy, (2) coordinate the policies of

${ }^{11}$ Much of this discussion is drawn from $\mathrm{Har}$ umitsu Yoshimura, The Organization of Science and Technology in Japan, prepared for the International Conference "The Organisation of Science and Technology in Western Industrialized Countries-An International Comparison" (Bonn, West Germany, May 26-27, 1987). Mr. Yoshimura is the Assistant Director General for Administration, Science and Technology Agency.

\section{Chart 12. Value of government R\&D funding [Constant 1982 dollars]}

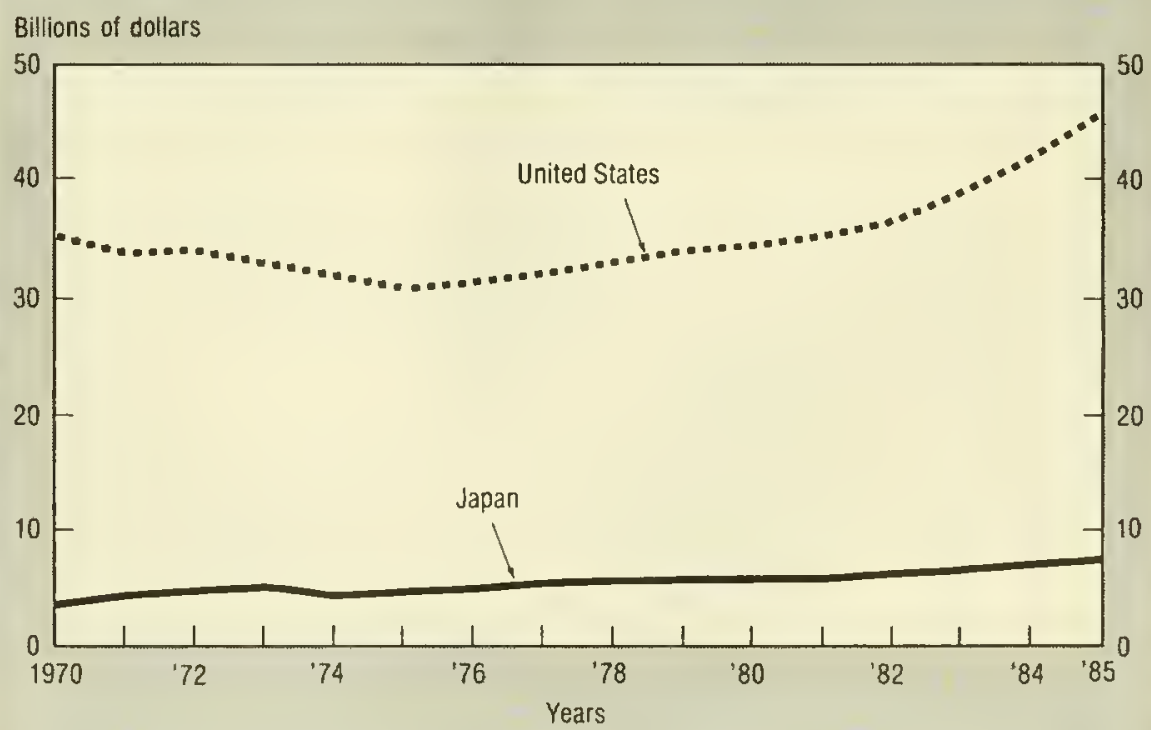

SOURCE: National Science Foundation, SRS, table 8-10 


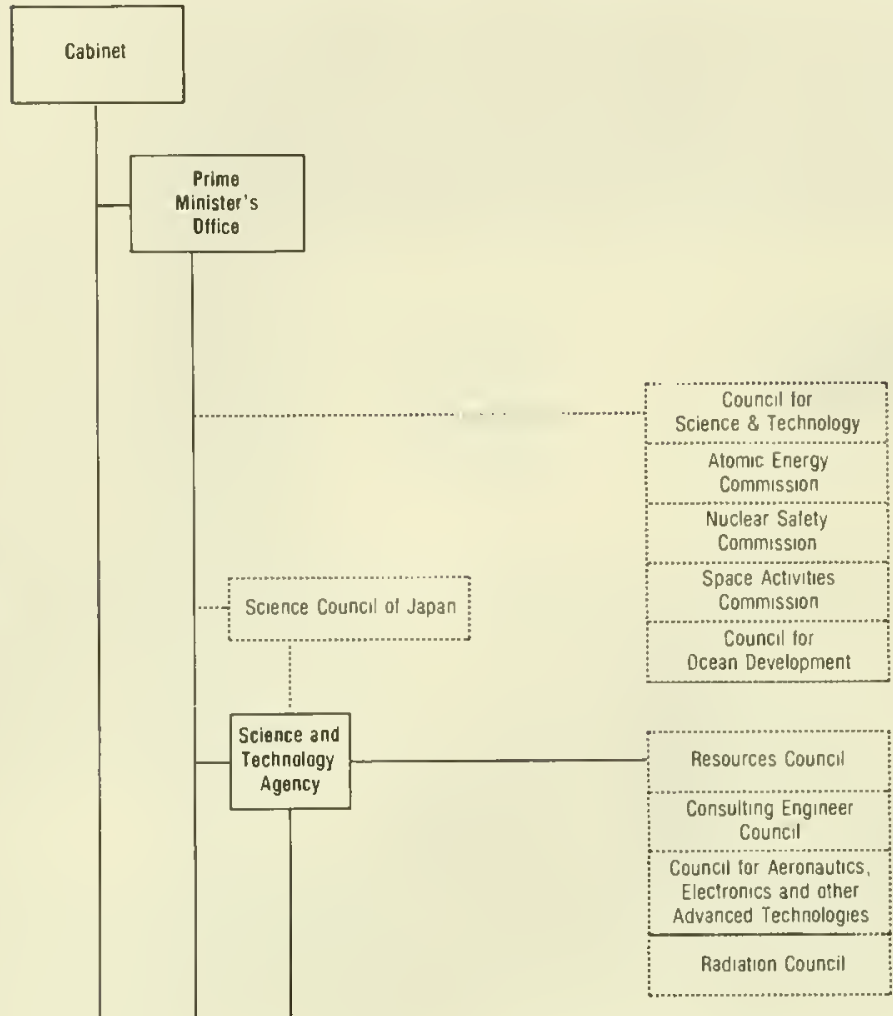

Attached Research Instiłutes

\begin{tabular}{|c|}
\hline $\begin{array}{c}\text { National } \\
\text { Aerospace Lab }\end{array}$ \\
\hline $\begin{array}{c}\text { National Res } \\
\text { Inst for Metals }\end{array}$ \\
\hline $\begin{array}{c}\text { National Inst } \\
\text { of Radiological Sciences }\end{array}$ \\
\hline $\begin{array}{c}\text { Natınal Res Center } \\
\text { for Disaster Prevention }\end{array}$ \\
\hline National Insi \\
for Research in \\
Inorganic Mäterials \\
\hline National Inst. of \\
Resources \\
\hline
\end{tabular}

Public Corporations

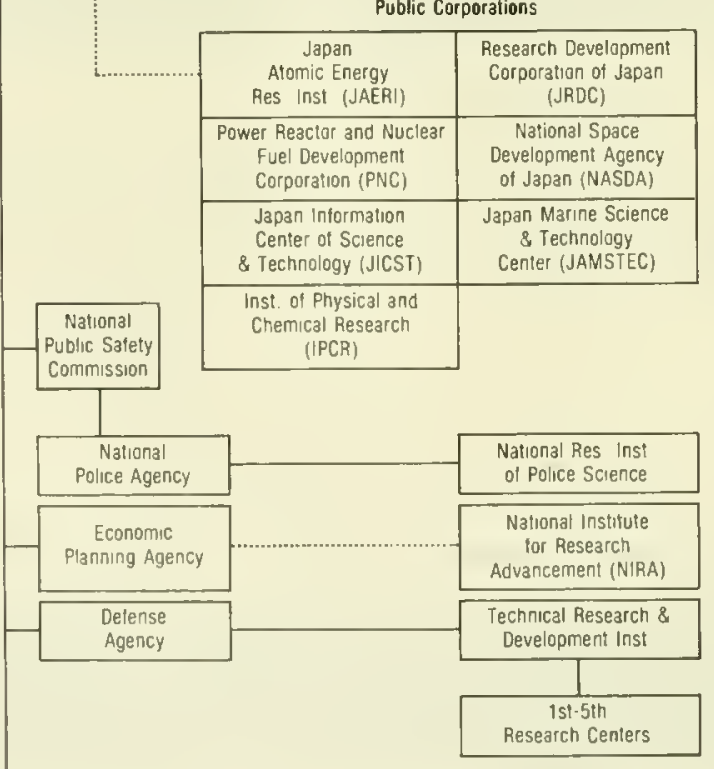

(1)

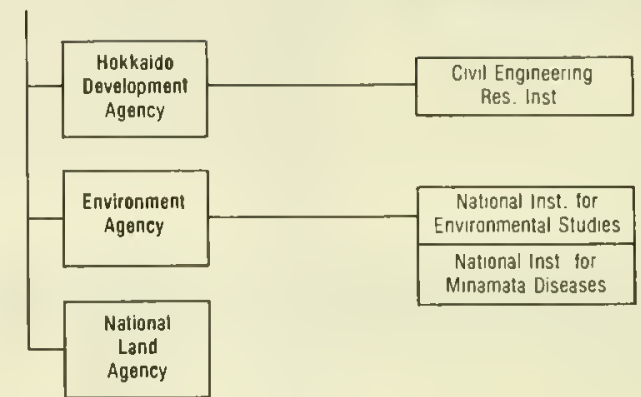

Minisiry

Aftairs

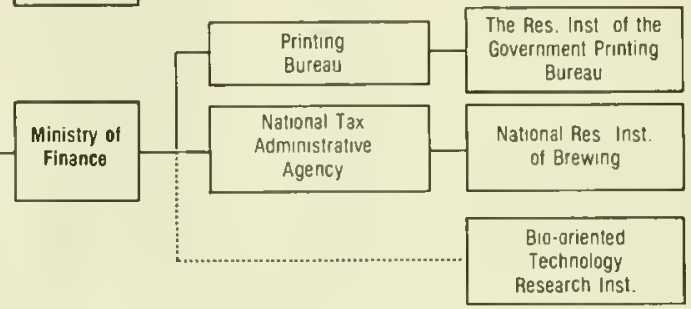

Ministry of

Education

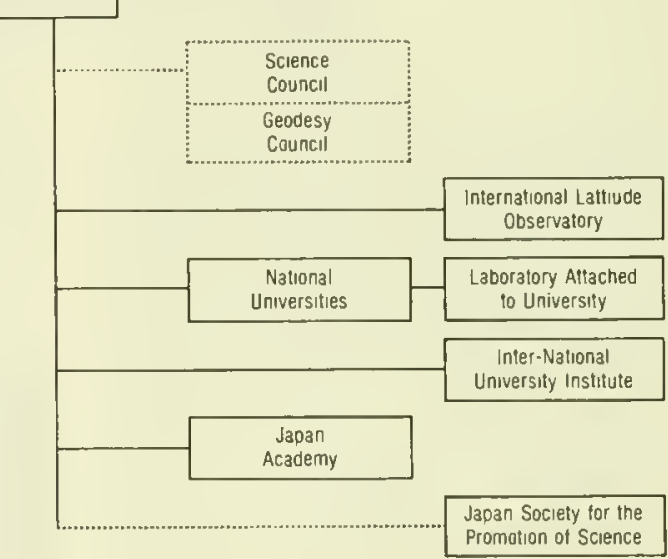
Promation of Science

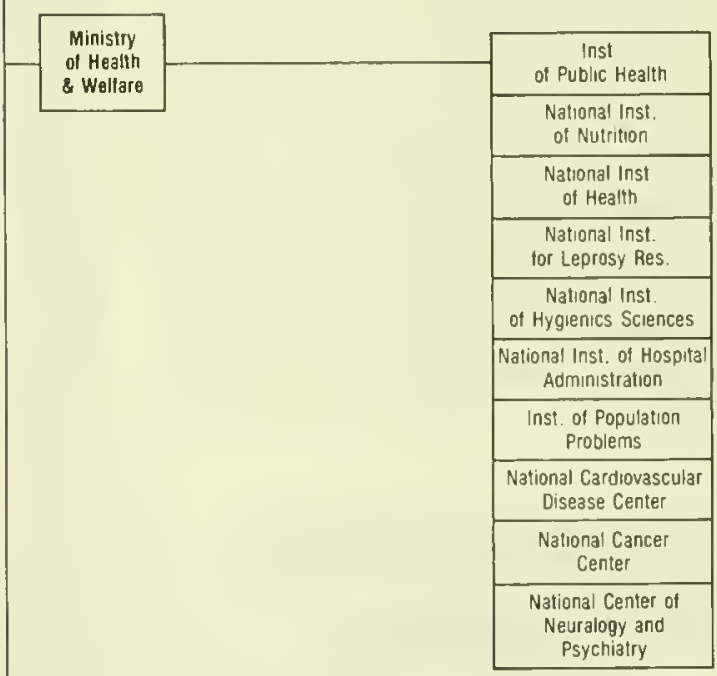




all ministries and agencies involved in science and technology, (3) direct a system of more than 80 government research institutes, (4) administer the national university system, and (5) oversee an assortment of public corporations.

The actual development of Japanese $\mathrm{S} / \mathrm{T}$ policy is a combination of consultation, consensus, decentralization, and coordination. The primary authority, the Council for Science and Technology, consults with the Prime Minister and Cabinet and recommends long-term national policy objectives. STA is responsible for coordinating the individual S/T policies of the various ministries (except Monbusho) and their affiliated research institutes. STA also contributes to the development of national S/T policy. Finally, Monbusho influences the R\&D activities of the national university system and its associated research institutions.

The council for science and technology. The Council for Science and Technology is the foremost Japanese institution for promoting a comprehensive national S/T policy; it also bridges the activities of STA and Monbusho. The Council is chaired by the Prime Minister and is composed of several cabinet ministers, the Chairman of the Science Council of Japan, and prominent experts on science and technology. In fulfillment of its role, the Council periodically delivers key recommendations to the Prime Minister. In 1965, the Council recommended that Japan should "seek relief through indigenous research and development from overdependence on foreign technology"; this recommendation was followed by a rapid increase in both government and private $R \& D$ funding. The Council's 1971 advice stressed the need for research on means to preserve the environment; the 1977 recommendation, following in the wake of the oil shock, focused on energy research. In November 1984, the Council released its Eleventh Recommendation, which identified the need for a "basic shift in Japan's R\&D effort towards the fostering of creative breakthroughs in fundamental research that should benefit not only Japan but the international community."12 This latter recommendation is expected to have a major impact on future Japanese $R \& D$ planning both in the character of research supported and the involvement of foreign researchers in its performance.

The science and technology agency. STA provides policy research and planning inputs for the Council, but its major responsibilities also include the management and conduct of $\mathrm{S} / \mathrm{T}$ activities in basic research and the "big sciences." Most of this work is carried out in research institutes attached to the agency; these perform work in such fields as aerospace, inorganic materials, and radiological science. Other work is performed by quasi-autonomous public corporations within STA's authority such as the Institute of Physical and Chemical Research (RIKEN) and the Japan Atomic Energy Research Institute.

Affiliated with STA is the Japan Information Center for Science and Technology (JICST), which collects $\mathrm{S} / \mathrm{T}$ publications from around the world, summarizes these, and stores the abstracts in an on-line service accessible to most Japanese researchers and now available in the United States. ${ }^{13}$ Another STA-directed public corporation is the Japan Research and Development Corporation,

\footnotetext{
${ }^{2}$ Council for Science and Technology, Compre hensive Fundamental Policy for Promotion of Science and Technology to Focus Current Changing Situations from the Long-Term View: Recommendation on the 11th In quiry (Tokyo, Japan, November 1984).

${ }^{13}$ The on-line service provides abstracts both in Japanese and English. It is available through the National Technical Information Service, Springfield, Va. 22161; phone number (703) 487-4819.
}

whose main function is to encourage the commercialization of promising $R \& D$ developed at the national universities and research institutes.

Among numerous other projects, STA publishes an annual "White Paper on Science and Technology" and sponsors a Delphi Survey administered every 5 years. This survey is sent to approximately 2,500 industry, university, and government leaders and asks them to identify those research areas deserving the highest emphasis. The results of the most recent survey are presented in chapter 6, "Possible Future Directions" (p. 39).

The ministry of education, science, and culture. Monbusho is responsible for administering Japan's system of 95 national universities and their affiliated research institutes, and accounts for the largest portion of government $R \& D$ expenditures. ${ }^{14}$ In order to foster interuniversity research cooperation, Monbusho established several research institutes for joint use by staff from all universities during the seventies. These institutes are both university-affiliated and independent national jointuniversity centers; by 1985 , there were 24 such institutes covering most major fields of investigation (a list of the institutes is provided on p. 24 in chapter 4, "Higher Education"). ${ }^{15}$ Similarly, Monbusho issued a directive in 1983 urging universities to open up their facilities to industrial researchers; since then it has initiated several programs promoting this

\footnotetext{
${ }^{14}$ Monbusho also sets the establishment and accreditation standards for Japan's public and private universities.

${ }^{15}$ An English-language description of these institutes is in the Tokyo Office of the U.S. National Science Foundation, Direclory of Selected Japanese Scientific Research Institutes: Government, National Universuties, and Special Corporations, Report Memorandum \#114, December 1986. The report may be obtained from the National Science Foundation Office of International Programs, 1800 G Street, N.W. Washington, D.C. 20550.
} 
university-industry-government cooperation in research. Also affiliated with Monbusho is the Japan Society for the Promotion of Science, a semigovernmental organization which provides (among other services) funds for cooperative research projects and fellowships for international scientific researchers.

Ministry of international trade and industry. MITI is well known for its role in industrial policy and regulation; however, it also plays an active part in promoting Japanese industrial R\&D. Within MITI, the Agency for Industrial Science and Technology (AIST) sponsors a variety of projects to develop technologies with potential commercial value. (These projects are further detailed on p. 66.) Much of this work is carried out in 16 national and re- gional industrial research institutes administered by AIST. AIST is also responsible for administering special incentives-such as conditional loans, tax deductions, and special financing-for technology development in the private sector. The Japan Key Technology Center, a public corporation affiliated with MITI/ AIST, helps finance certain joint industrial R\&D projects.

\section{government funding}

Ministerial R\&D budgets are composed of: (1) funds for ongoing research-related operations and personnel costs of government research institutes and higher educational institutions, (2) funds for research promotion-primarily in the form of external grants, and (3) funds for the special energy budget initiated in 1977.

Monbusho and STA have the largest budgets, accounting for 47 percent and 27 percent, respectively, of the Government's total R\&D budget (chart 14). MITI is the third largest funder (13 percent); followed by the Ministry of Agriculture, Forestry, and Fisheries and the Defense Agency (4 percent each); and the Ministry of Health and Welfare (2 percent). While most of Monbusho's funds are committed to the ongoing operations of the university system, STA's funds are equally divided among the three funding components listed above.

The Japanese Government spends the largest portion of its budget-an estimated 47 percent in 1985 - on the general objective of "advancement

Chart 14. R\&D budgets of key Japanese ministries and agencies: 1985

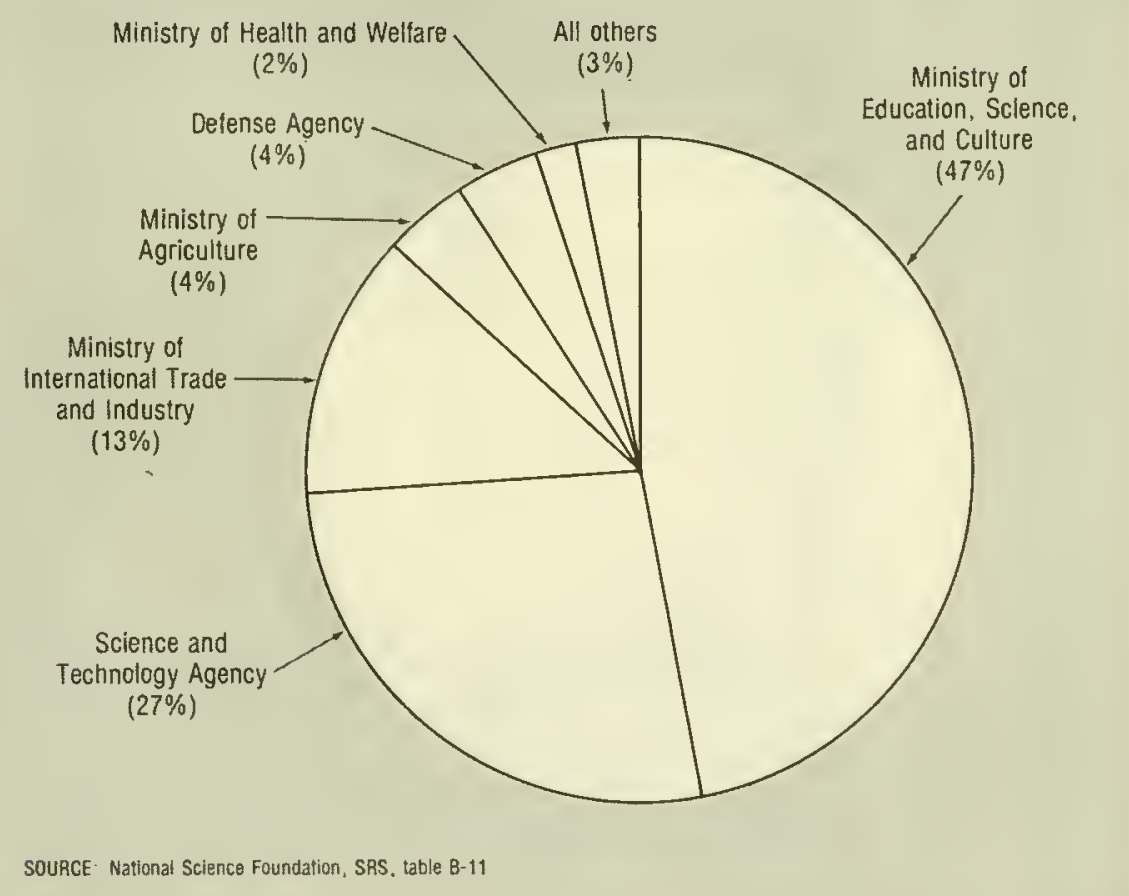


of knowledge," a function which includes general university funds (GUF) spent on R\&D as well as separately budgeted $R \& D$, and should also not be equated with basic research (chart 15). ${ }^{16}$ The U.S. Government spends the preponderance of its R\&D budget (68 percent in 1985) on defense.

The emphasis of the Japanese Government on various $R \& D$ objectives has been relatively stable over the past decade, with the exception of the shares of funds devoted to energy and defense research. From 1975 to 1985, the proportion of expenditures for energy R\&D doubled, rising from 7.5 percent to 16.3 percent; defense expenditures increased from 2.2 percent to 4.1 percent. The relative shares of all other categories declined to compensate for these increases (chart 16). Japan spends a greater proportion of its budget on agriculture, industrial development, energy, and civil space objectives than does the United States, largely because of its much lower concentration of defense-related $R \& D$ expenditures.

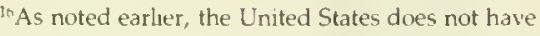
the Japanese and European equivalent of general university funds; the U.S. data on advancement of knowledge do not include expenditures similar to GUF. Also note that approximately one-half of the Japanese Government R\&D budget goes to the Ministry of Education, Science, and Culture.
}

Chart 15. Distribution of government R\&D funding by objective: 1985

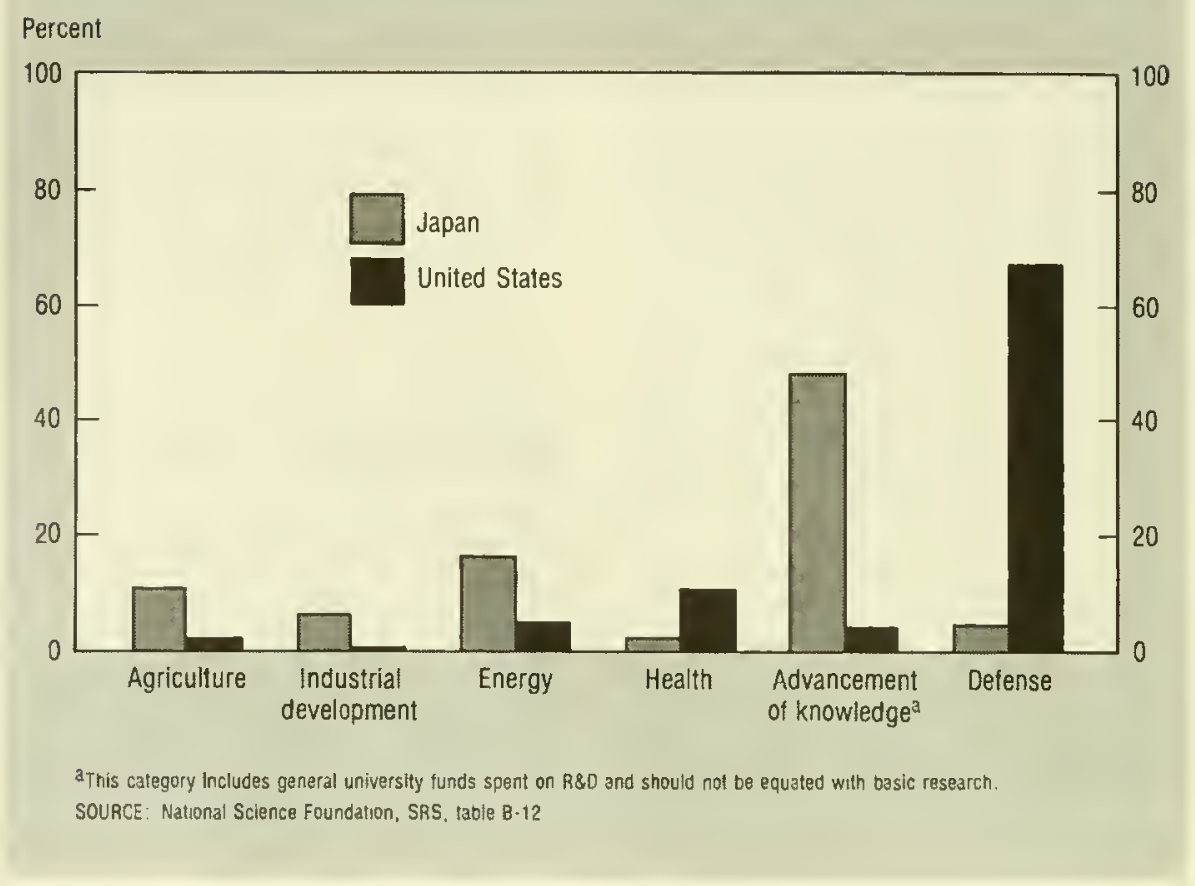

Chart 16. Japanese Government A\&D funding by objective

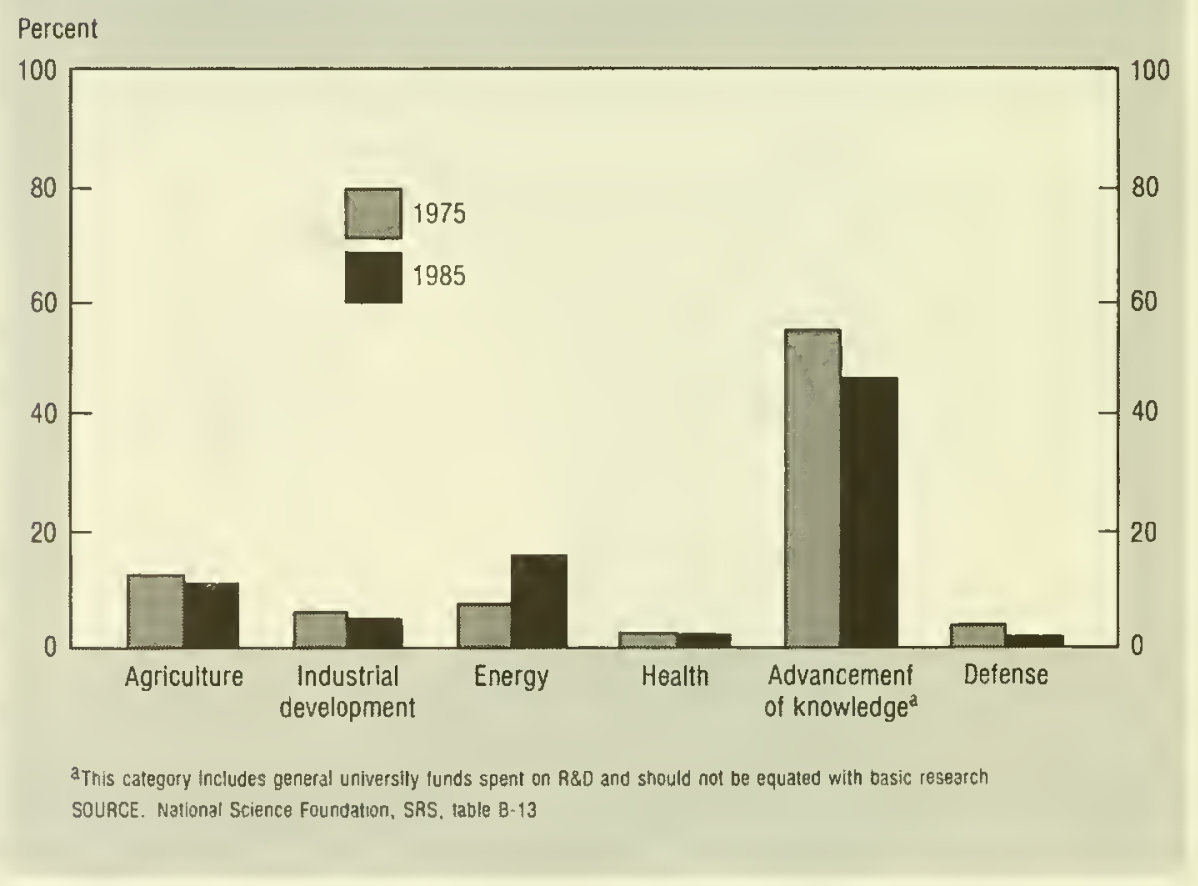




\section{government r\&d programs}

In addition to its funding and policymaking roles, the Japanese Government is a performer of $R \& D$ through the more than 80 national institutes and public corporations which conduct ongoing research. ${ }^{17}$ In addition to ongoing research at the research institutes, there are a number of large-scale, special R\&D programs that have been initiated by STA and MITI which focus primarily on basic research and the development of new technologies.

The Exploratory Research for Advanced Technology program (ERATO) was implemented in 1981 to provide basic research in potentially revolutionary technologies that are of prohibitive research cost to private industry. ERATO is directed by the Research Development Corpo-

\footnotetext{
${ }^{17} \mathrm{~A}$ listing and description of the most significant of these research institutes is in the Tokyo Office of the U.S. National Science Foundation, Directory of Selected Japanese Scientific Research Institutes, op. cit.
}

ration of Japan, and research outputs are to be made publicly available for commercial exploitation. Through 1986, 12 different projects - with average expected durations of 5 years and average total budgets of constant (1982) \$8 million-have been adopted. These projects are listed in table C-1.

Within MITI, AIST has established several well-publicized joint research enterprises with selected industrial firms (e.g., the Large-Scale, Sunshine, and Moonlight Projects). MITI provides these projects with partial funding and, in some instances, also provides the facilities of its research institutes; the firms contribute key researchers and the remaining funding. A list of major AlST projects and their purposes are presented in table $\mathrm{C}-2$. MITI also sponsors the Fifth Generation Computer Program, a 10-year research program instituted in 1982 . Research in conjunction with the Fifth Generation Computer Program is conducted at the specially created Institute for New Generation Computer Technology (ICOT), and focuses on advanced information processing, especially parallel computing and artificial intelligence.

Finally and most recently, the Frontier Research Program was initiated in 1986 under the aegis of RIKEN, a major research institute affiliated with STA. The program aims to discover new knowledge that will serve as the basis for technological innovation in the 21st century; the two research themes of the program are (1) the biological foundations of homeostasis mechanisms in plant and animal life, and (2) frontier materials. A 15-year research agenda is tentatively being planned, with teams of international scientists conducting research at RIKEN's laboratories in specific areas such as chromosomes and bioelectronic elements and devices. ${ }^{18}$

\footnotetext{
18For more information on RIKEN"s program, see the Tokyo Office of the U.S. National Science Foundation, STA and RIKEN to Launch 'International Frontier Research System', Report Memorandum \#97, April 1986. Note that RIKEN's IFRP is not the same as the yet-to-be implemented Human Frontiers Program. The Human Frontiers Program has been a highly publicized new research program, and is still in the planning stage.
} 



\section{chapter 3.}

\section{industrial r\&d}

Industrial $R \& D$ has always been the most prominent sector in the Japanese system, accounting for 69 percent of all R\&D funds in 1985 (U.S. industry accounted for 49 percent of R\&D funds). There are two primary reasons for this sector's prominence. First, Japan's postwar agreements have limited Japan's defense establishment; consequently, the share of $R \& D$ funds accounted for by government defense-related $R \& D$ expenditures is very small in Japan. Second, the Japanese Government has maintained a policy of letting industry support its own $R \& D$, with the result that less than 2 percent of industrial R\&D funds comes from the Japanese Government. In contrast, in the United States, slightly more than one-third of industrial $R \& D$ is funded by the Federal Government; these expenditures are concentrated primarily in the defense, space, and telecommunications industries.
Low levels of government R\&D expenditures relative to industry do not mean that the Japanese Government does not actively encourage or promote industrial R\&D. In fact, a system of financing and tax incentives operates to stimulate $R \& D$ in the Japanese private sector. Projectoriented incentives for encouraging Japanese industrial R\&D include favorable interest rates from the Japan Development Bank for the commercialization of new technology, government contracts for the commercialization of the outputs of public R\&D institutions, capital investments, and conditional interestfree loans. Tax incentives-which allow Japanese businesses to maintain the confidentiality of their R\&D activities (unlike the project-oriented incentives)-provide special tax credits for incremental increases in corporate $R \& D$ expenditures (in effect since 1967); the R\&D per- formed by small and medium firms; and the costs of depreciable assets for R\&D in "basic" technologies such as new materials, biotechnology, and high-performance robotics. ${ }^{19}$ In comparison, the United States provides tax credits only for incremental corporate $R \& D$ expenditures and industry funding of university basic research; the credit was first initiated in 1981 and later extended (in a reduced and modified form) through 1988.

\footnotetext{
${ }^{19} \mathrm{~A}$ detailed discussion of Japanese industrial financing and tax incentives is in Ministry of International Trade and Industry, AIST, 1987 (Tokyo, Japan, 1987). A thorough discussion of the R\&D tax system is in the Tokyo Office of the U.S. National Science Foundation, Preferential Tax Systems for RED in Japan, Report Memorandum \#109, November 1986.
} 


\section{overall industrial r\&d trends}

From 1965 to 1985, Japanese industrial $R \& D$ expenditures increased at an average annual rate of 11 percent; total U.S. industrial R\&D increased at a rate of 3 percent and U.S. company-funded R\&D at a rate of 5 percent for the same period. ${ }^{20}$

Consequently, Japanese industrial R\&D expenditures increased from less than one-tenth the U.S. level in 1965 to one-third of total U.S. industrial R\&D and one-half of U.S. company-funded $R \& D$ expenditures in 1986 (chart 17). Japanese industrial R\&D expenditures were constant $\$ 24.1$ billion in 1985 (constant $\$ 396$ million were funded from government sources) compared with total U.S. industrial expenditures of constant $\$ 70.4$ billion (constant $\$ 23.8$ billion from government sources).

As a percentage of GNP, Japanese industrial $R \& D$ more than doubled from 1965 to 1986 . In 1986 this ratio was comparable to the U.S. proportion: 1.9 percent and 2.0 percent, respectively (chart 18). Since Japanese industrial R\&D is almost entirely ( 98 percent) financed by companies themselves, Japanese companyfunded R\&D as a percentage of GNP has surpassed the U.S. ratio in every year since 1970. In 1985 and 1986, the ratio of company-funded $R \& D$ to GNP was 1.9 percent for Japan and 1.3 percent for the United States.

\footnotetext{
${ }^{20}$ Because less than 2 percent of Japanese industrial R\&D funds is from government sources, Japanese company-funded R\&D data are not discussed separately.
}

\section{Chart 17. National industrial R\&D expenditures [Constant 1982 dollars]}

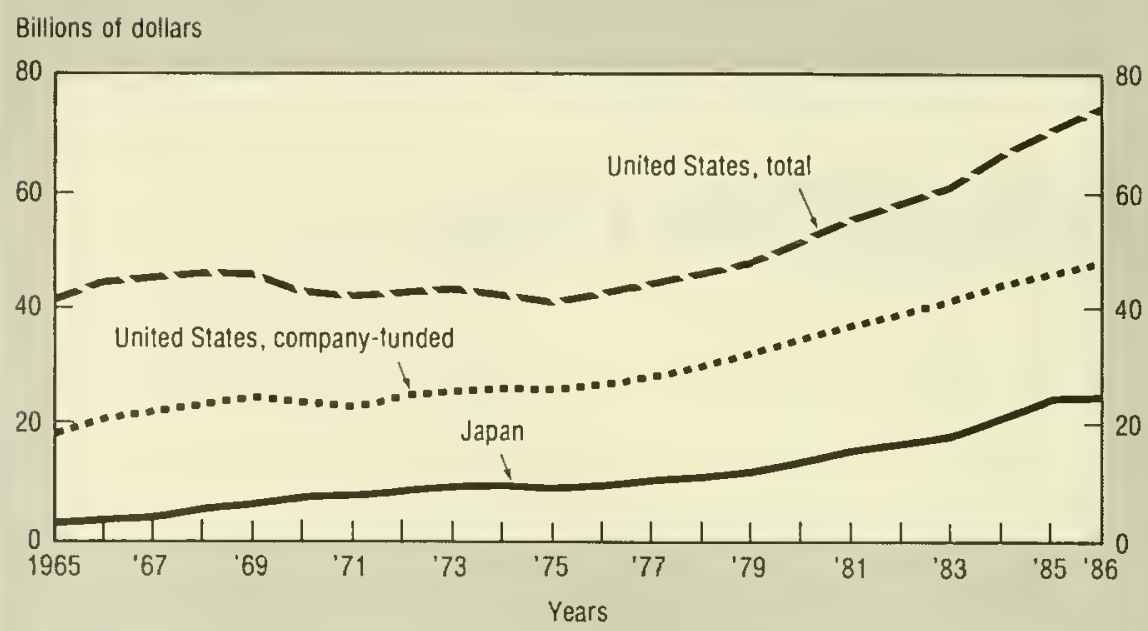

NOTE. Because less than 2 percent of Japanese industrial h\&0 funds comes from government sources, a separate companyfunded data series has not been provided

SOURCE National Science Foundation, SAS, lable B-14

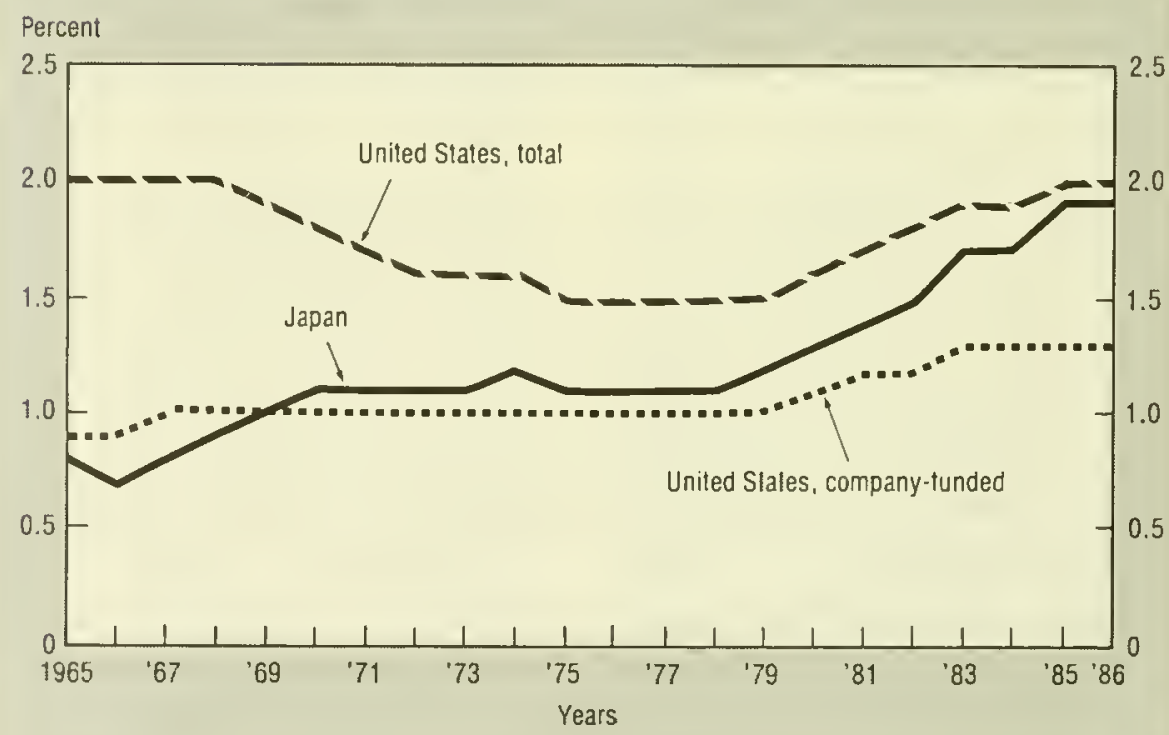

NOTE Japanese industral R\&O is almost 98 percent company-funded SOURCE: National Science foundation, SRS, table B-15 


\section{r\&d by industry}

Because of the congestion and pollution created by the geographic concentration of Japan's heavy industries, Japan's economic planners have de-emphasized industries perceived as environmentally disruptive (e.g., chemicals, steel) and introduced policies to replace them with those perceived as environmentally clean and/or informationbased (e.g., electronics, scientific and professional instruments). Industrial $R \& D$ investments appear to have been somewhat responsive to these priorities.

In 1965, the chemical industry in Japan was the principal performer of R\&D, accounting for 28 percent of total manufacturing R\&D; it was followed by the electrical machinery industry, which accounted for 23 percent (chart 19). ${ }^{21}$ By 1975, electrical machinery had overtaken the chemical industry as the primary R\&D performer, and-by 1985-the electrical machinery industry was outspending the chemical industry 2 to 1 . In both 1965 and 1985, the electrical machinery, chemicals, general machinery, and motor vehicles industries were the four largest sources of Japanese manufacturing $R \& D$, together accounting for 68 percent of manufacturing R\&D in 1965 and 73 percent in 1985. The industries

2"The Standard Industrial Classification for Japan includes computers under the "electrical machinery" classification as communications equipment and electronic components, whereas the United States and the Organisation for Economic Co-operation and Development classify such equipment under "general machinery." with the largest real $R \& D$ growth from 1965 to 1985 were communications and electronic equipment, rubber (including plastics), motor vehicles, and professional and scientific instruments.

The United States has a different ranking of the top sources of manufacturing $R \& D$ depending on whether total or company-funded $R \& D$ is examined. For total manufacturing $R \& D$, aircraft and missiles account for 23 percent of R\&D performance; electrical machinery, general machinery, and chemicals industries combined account for another 47 percent of the total manufacturing $R \& D .{ }^{22,}{ }^{23}$ For companyfunded manufacturing $R \& D$, the electrical machinery industry is the single largest source of manufacturing $R \& D$ ( 34 percent), followed by the chemical (16 percent), motor vehicle (12 percent), and professional and scientific instruments ( 9 percent) industries. ${ }^{24}$

\section{Chart 19. Distribution of Japanese total manufacturing R\&D among selected industries: selected years}

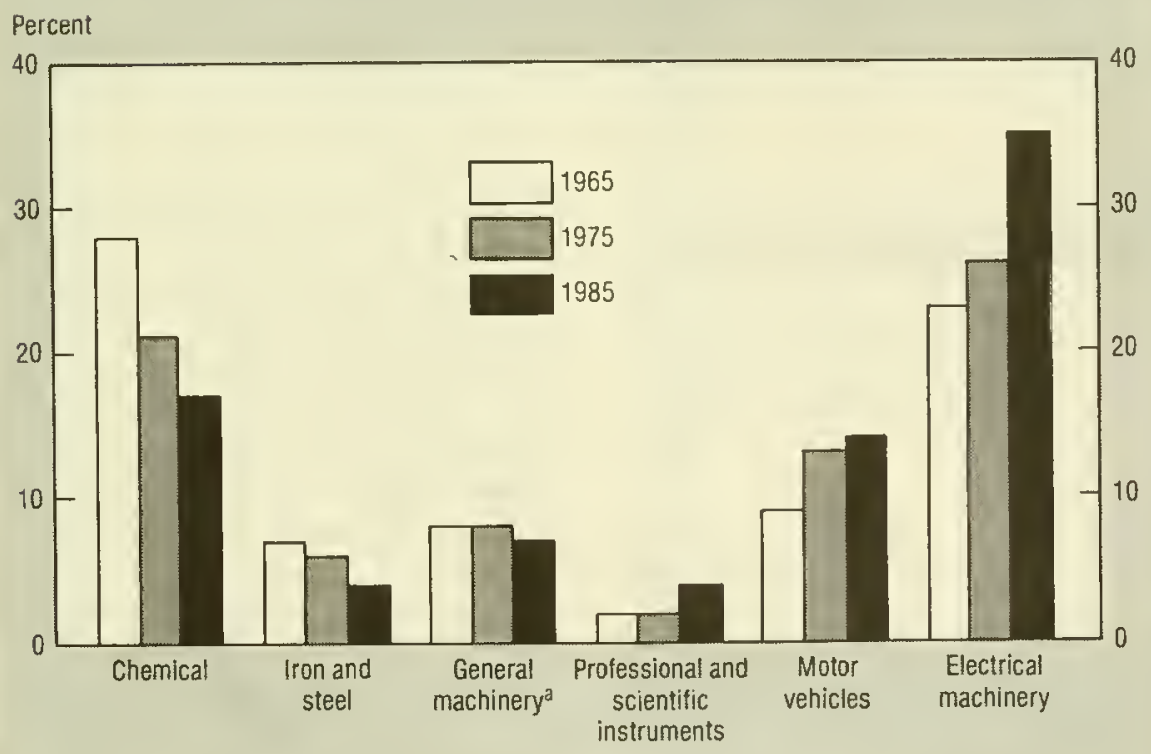

a Note that unlike the United States, in Japan computers are classified as electrical - not general - machinery SOURCE: National Science Foundation, SRS. table B-16

\footnotetext{
2Unlike the United States, Japan does not have a separate industry category for aircraft and missiles, probably because these industries are so small Missiles are not mentioned at all in the product classifications; ordnance is included in general machinery and aircraft are included in the category for transportation equipment other than motor vehicles. In 1985, R\&D expended hy "other transportation" industries was constant \$561 million with an $R \& D$ to net sales ratio of 2.6 percent.

${ }^{23}$ Much of the total U.S. manufacturing R\&D is not available on a sufficiently disaggregated basis to allow for a detailed industry comparison with Japan.

${ }^{24}$ Note that the U.S. manufacturing industry data have been adjusted to be more comparable with the Japanese data. Computers have been reclassified from general machinery to communications and electronic equipment under electrical machinery.
} 
By 1985, most Japanese manufacturing industries were investing at least one-half of the company-funded R\&D amount of their U.S. counterparts (chart 20). In the textiles, ceramics, and iron and steel industries, actual Japanese $R \& D$ expenditures exceeded U.S. levels by nearly 2 to 1 or more. In only two industriespetroleum and professional and scientific instruments-were Japanese $R \& D$ expenditures significantly less than one-half that of the U.S. These high levels of industrial R\&D expenditures are particularly impressive if it is recalled that in 1985 Japan's GNP was little more than one-third of the United States'.

\section{r\&d to net sales and r\&d concentration}

The relative importance of $R \& D$ can be gauged by measuring the proportion of available resources being invested in $R \& D$. The ratio of company-funded $R \& D$ expenditures to net sales provides a measure of R\&D intensity which can be compared across industries and countries. This ratio for all Japanese manufacturing industries in 1985 was 2.7 percent-slightly less than the 2.8 percent reported for companyfunded $R \& D$ in the United States (chart 21). Generally, those Japanese industries with $R \& D$ expenditures

Chart 20. R\&D expenditures in manufacturing by selected industries: $1985^{\mathrm{a}}$ [Constant 1982 dollars]

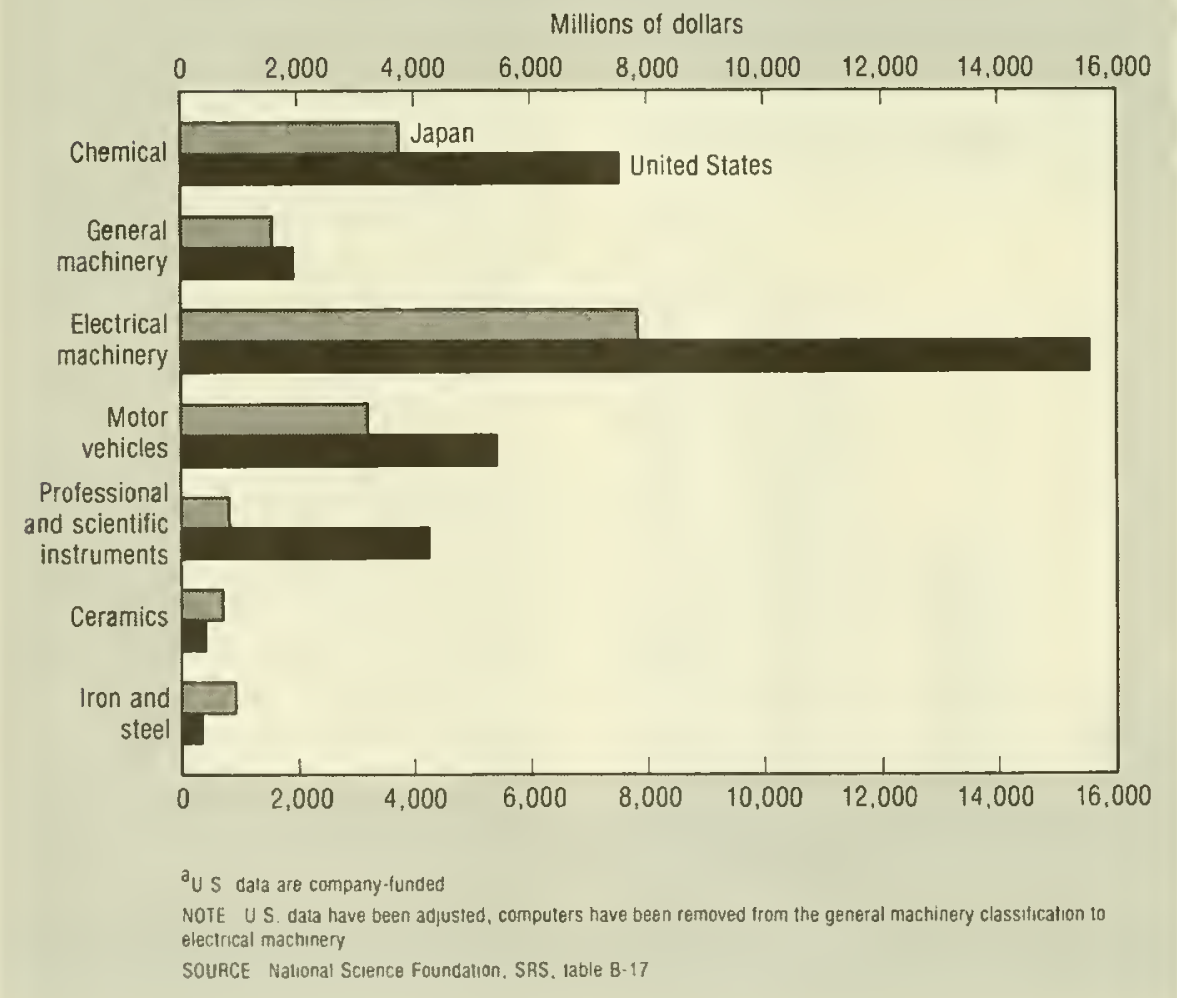

equivalent to about 60 percent or more of their U.S. counterparts had the same or higher $R \& D$ to net sales ratios as the U.S. industries; Japanese industries with R\&D expenditures equivalent to less than about 60 percent of U.S. industries had ratios lower than those for the United States. Drugs and medicines was the most R\&D-intensive industry in Japan with an $R \& D$ to net sales ratio of 7 percent; it was followed by communications and electronic equipment ( 5.3 percent) and professional and scientific instruments (4.5 percent). In the United States, the professional and scientific instruments ( 9 percent), drugs and medicines $(8.4$ percent), and communications and electronic equipment ( 7.6 percent) industries were the most R\&D intensive.

Evidence indicates that $R \& D$ is slightly less concentrated in Japan than in the United States. In 1985, the top five Japanese R\&D firms accounted for 18 percent of total manufacturing R\&D compared to 23 percent for the top five U.S. firms (table B-18). For most manufacturing industries, the levels of industrial $R \& D$ concentration are lower in Japan than in the United States; an appreciably higher level of Japanese industrial $R \& D$ dominance is found only in the iron and steel industry. U.S. company-dominance of R\&D is much higher than Japan's in the industrial chemicals, ceramics, fabricated metals, general machinery, motor vehicles, and professional and scientific instruments industries.

In Japan, the greatest levels of company concentration of manufacturing $R \& D$ occurred in the iron and steel (78 percent of $R \& D$ accounted for by the top five R\&D firms), petroleum and coal (71 percent), motor vehicles ( 69 percent), and rubber ( 60 percent) industries. In the United States, the concentration was highest in the motor vehicles (96 percent), petroleum and coal (71 percent), industrial chemicals (70 percent), and professional and scientific instruments (65 percent) industries. 
Chart 21. Ratio of company-funded R\&D expenditures

to net sales in selected industries: 1985

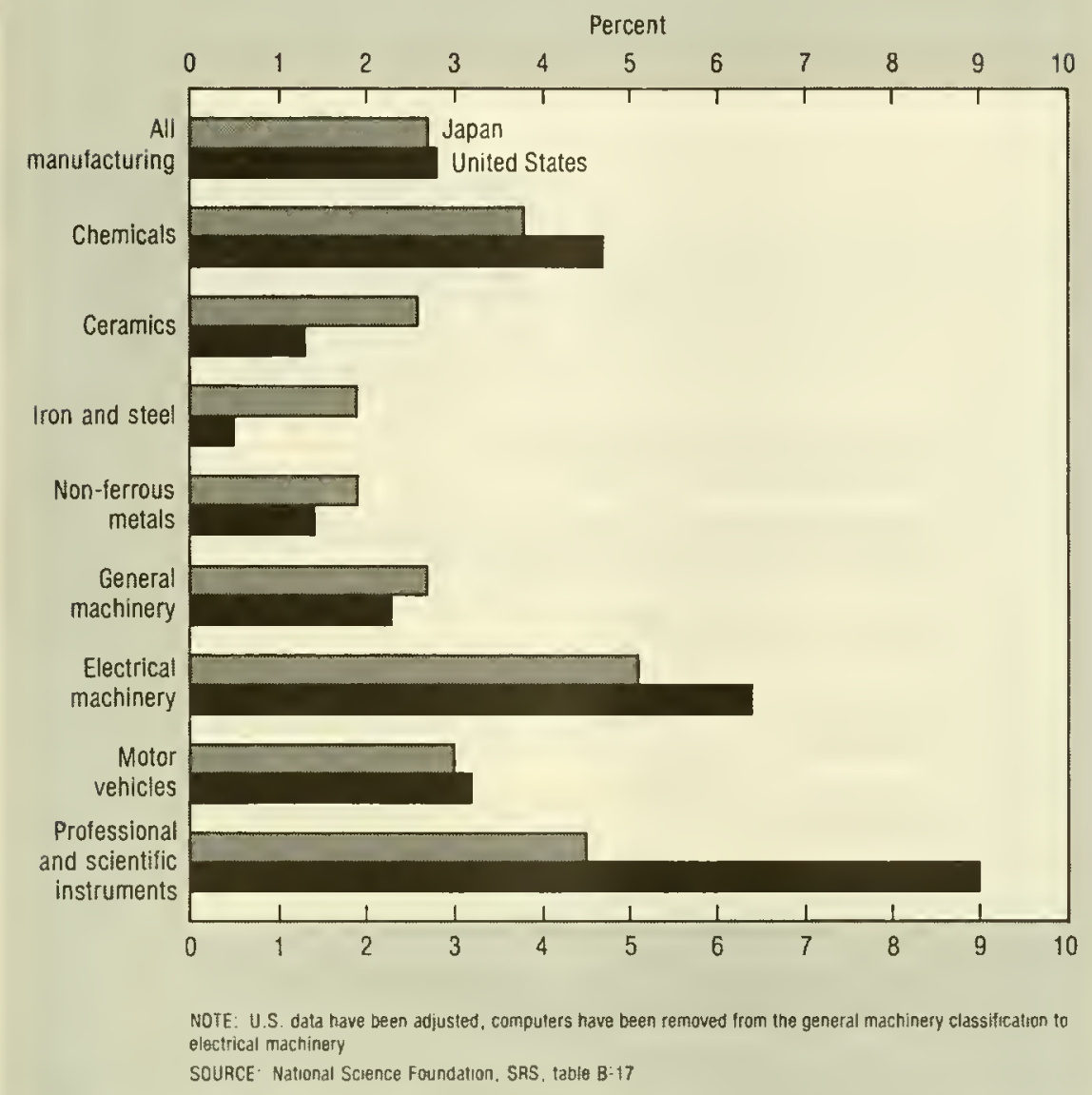

The most $R \& D$-intensive industries were not the most R\&D-"monopolized" industries in either country. In Japan, the most R\&Dintensive industries (pharmaceuticals, communications and electronic equipment, and professional and scientific instruments) had less than 60 percent of their $R \& D$ accounted for by the top five firms. In the United States, the most R\&D-intensive industries (professional and scientific instruments, pharmaceuticals, and communications and electronic equipment), had 65 percent or less of their R\&D accounted for by the top five firms.

\section{industrial scientists and engineers engaged in r\&d}

Accompanying the growth of industrial R\&D expenditures is the increase in industrial scientists and engineers engaged in R\&D. In 1965 , there was a total of 59,000 Japanese scientists and engineers engaged in industrial R\&D; this represented about one-fifth the U.S. 348,000 fulltime equivalent. During the past 2 decades the number of Japanese in- dustrial R\&D scientists and engineers has increased at an average annual rate of 7.1 percent, compared to 2.5 percent for the United States. Thus, by 1985 Japan employed 231,000 scientists and engineers engaged in industrial $R \& D$ two-fifths as many as the 570,000 fulltime equivalent in the United States (table B-19). Although Japan has a lower absolute number of industrial scientists and engineers, Japan's 1985 ratio of manufacturing $R \& D$ scientists and engineers per 10,000 employees was 470 compared to the 400 full-time equivalent for the United States (chart 22). 
Chart 22. Number of industrial scientists and engineers engaged in R\&D per 10,000 employees for selected manufacturing industries: 1985

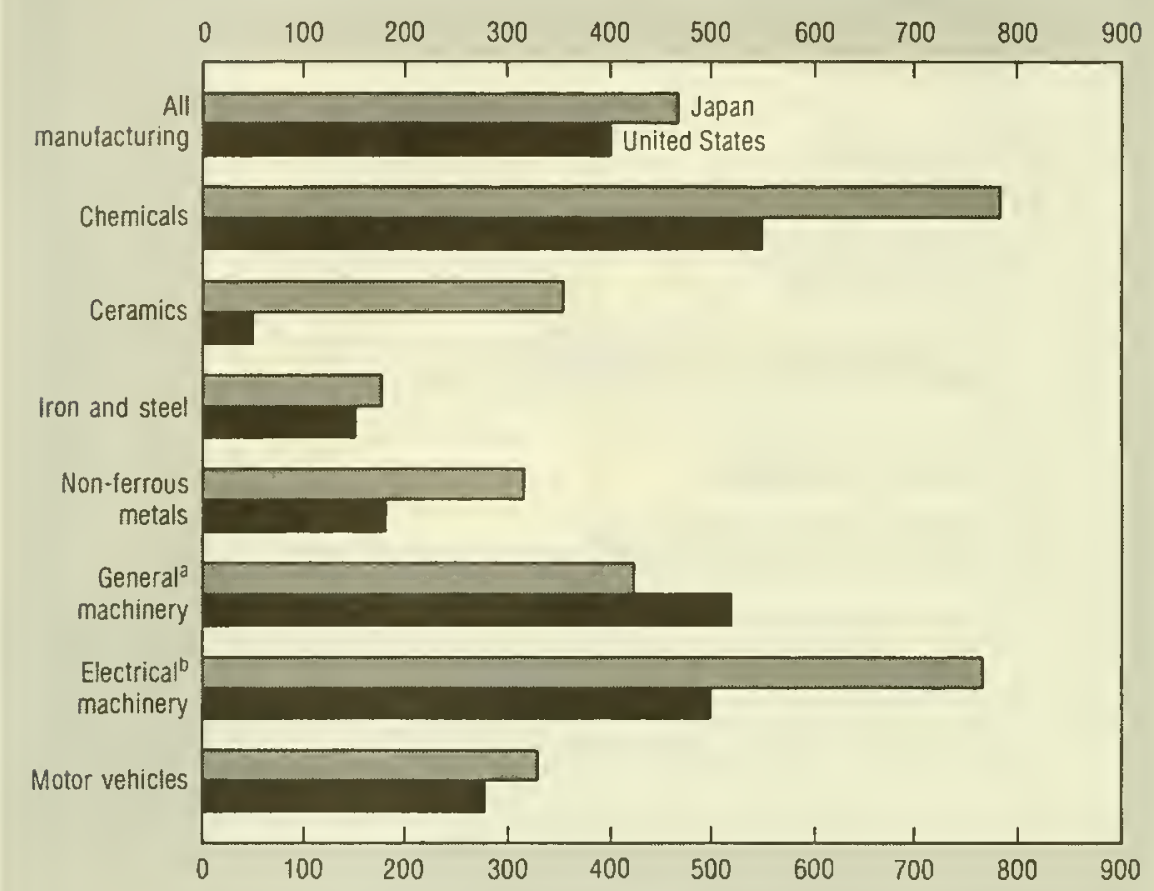

a Number of U.S. scientists and engineers are in full-time equivalents; Japanese are total numbers of screntists and engineers engaged in $\mathrm{R} \& \mathrm{D}$.

${ }^{t}$ These calegories are not comparable for the United States and Japan because they represent diferent SIC product groupings U.S. Includes compulers, whereas computers are classitied under electrical machinery in Japan. SOURCE. National Science Foundation. SAS, table 8-17 


\section{chapter 4.}

\section{higher education}

Because the Japanese and U.S. higher education systems are very different, it is difficult to make international comparisons of the resources devoted to R\&D in the higher education sector. For the purposes of this discussion, the Organisation for Economic Co-operation and Development (OECD) definition of higher education is used: it comprises all universities, colleges of technology, and other institutes of post-secondary education whatever their legal status or source of funding; and includes all research institutes, experimental stations, and medical facilities operating under the direct control of, administered by, or associated with higher education establishments. For instance, in the United States, R\&D expenditures in the higher education sector include those funds spent not only in uni- versities and colleges but also in federally funded research and development centers (FFRDCs) administered by individual universities and colleges and by university consortia.

Japan's university research system is composed of three types of institutions: universities, research institutes attached to universities, and National Interuniversity Research Institutes. ${ }^{25}$ The university system consists of 96 national universities established under the authority of the Ministry of Education, Science, and Culture (Monbusho); 34 public institutions established by local governments; and 331 private

\footnotetext{
${ }^{25}$ The above discussion of the Japanese higher education research system is drawn from the Ministry of Education, Science, and Culture, The Uniwersity Research System in Japan (Tokyo, Japan, 1986).
}

institutions. R\&D is also conducted at an assortment of junior and technical colleges which account for about 10 percent of the academic staff in the entire higher education system.

Research at the university level is also conducted in research institutes established within the universities as well as in the National Interuniversity Research Institutes. Recent policy emphasis has been on the cooperative use of research facilities: of the 69 institutes attached to the national universities, 12 are available for joint use. The more than 500 research institutes affiliated with public and private universities are devoted primarily to the humanities and social sciences.

To promote research and academic cooperation in those fields of science which require large-scale facilities and equipment or collective 
research, Japan established $12 \mathrm{Na}$ tional Interuniversity Research Institutes in the 1970's (table 2). These institutes are not attached to specific

\section{Table 2. Joint university and national interuniversity research institutes}

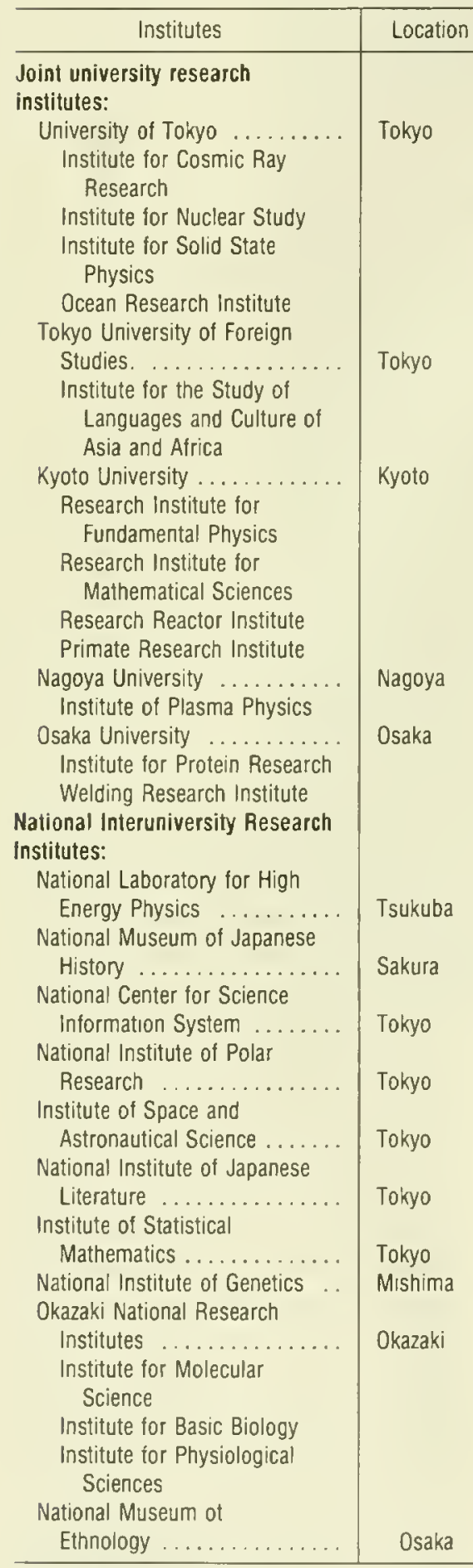

SOURCE Ministry of Education, Science, and Culture. The University Research System in Japan (Tokyo, Japan, 1986) universities, are open to all university researchers, and are of the same legal classification as the national universities.

While the U.S. system relies mostly on separately budgeted R\&D project awards, Japan principally depends on an institutional funding system in which universities and colleges receive GUF from the national Government for teaching, research, and facilities and equipment. Threequarters of all Japanese higher education R\&D funds are received through such general funds, whereas over three-quarters of U.S. higher education R\&D funds are obtained from specifically budgeted project items. ${ }^{26}$

\section{overall r\&d trends}

The higher education sector appears to play a larger role in the Japanese $R \& D$ system than that in the United States. In 1985, 31 percent of Japan's natural scientists and engineers engaged in $R \& D$ were in higher education (60 percent of Japanese natural scientists and engineers engaged in $R \& D$ are in health-related fields). In contrast, 14 percent of the U.S. natural scientists and engineers engaged in R\&D were in higher education. As a share of total R\&D, R\&D performance in 1985 in the higher education sector accounted

\footnotetext{
${ }^{26}$ These data are presented in Ben Martin and John Irvine, An International Comparison of Government Funding of Academic and Acalemically Relnted Research (Sussex, England: University of Sussex, Science Policy Research Unit, 1986). The United States does not have the equivalent of GUF; Martin and Irvine have attempted to identify and include those U.S. funds that are comparable to GUF.
}

for 20 percent in Japan and 12 percent in the United States. ${ }^{27}$ In both Japan and the United States, the higher education sector conducts comparable shares (55-56 percent) of the national basic research effort.

From 1965 to 1986, R\&D performance in the higher education sector more than tripled in constant dollar terms in Japan and doubled in the United States (chart 23). Japanese expenditures increased at an average annual rate of 6.1 percent, compared with 3.2 percent in the United States. In 1986, R\&D expenditures in Japanese higher education totaled constant $\$ 7.3$ billion; U.S. expenditures totaled constant $\$ 12.7$ billion. As a share of total R\&D, Japanese higher education R\&D declined from 36 percent in 1965 to 20 percent in 1986 (chart 24). This was largely because of the higher average annual rates of increase in $R \& D$ expenditures by industry, government, and private research institutes. In comparison, U.S. higher education expenditures as a share of total $R \& D$ increased slightly, rising from 11 percent in 1965 to 13 percent during 1975-81; expenditures have remained at 12 percent since 1982.

In Japan, as in most European countries, higher education statistics relating to $R \& D$ revenues and expenditures include a sizable portion of GUF, which includes normal operating expenses. A recent study by Martin and Irvine ${ }^{28}$ illustrates the implications of including a proportion of such funds for computing government-funded academic research. Of Japan's governmentfunded academic research, the study found that 75 percent is allocated for GUF, compared with the study's es-

\footnotetext{
${ }^{27}$ If the United States had data on and included data from State and local governments, this 12-percent share for the higher education sector would likely be higher.

${ }^{28}$ Martin and Irvine, op. cit
} 
Chart 23. R\&D expenditures in the higher education sector

[Constant 1982 dollars]

Billions of dollars

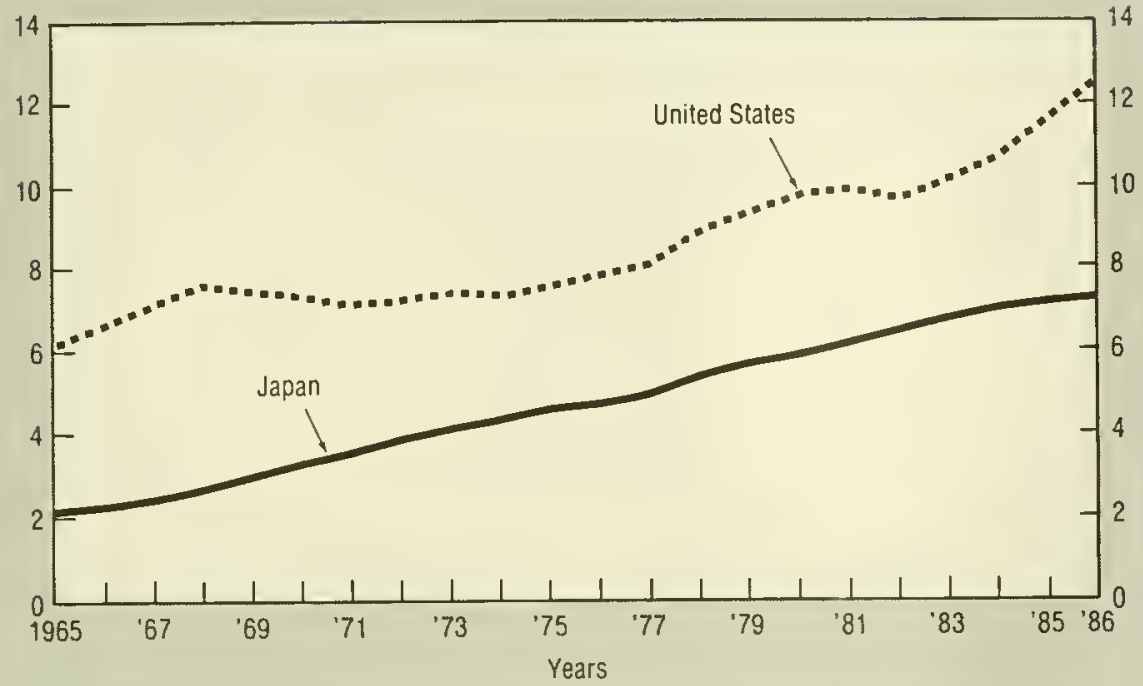

SOURCE. National Science Foundation, SPS. table 8-20 timated 23 percent for the United States (table 3). Monbusho reports that of its budget for promoting scientific research, equal shares ( 38 percent each) go to research institutes and national university facilities; 13 percent is allocated for scientific research grants; and the remaining 11 percent goes to all other programs including, for example, the Antarctic program and subsidies to public and private universities.

Private higher educational institutions occupy a major place in the Japanese system, employing about one-half of all university researchers (38 percent of the scientists and engineers engaged in $R \& D$ in the natural sciences and engineering) and accounting for nearly three-quarters of all student enrollments. Further, they account for a substantial proportion of the funds expended on higher educational R\&D: 53 percent of the 1985 total. The research activities of private universities place greater relative stress on applied topics, especially in medicine and the social sciences, than do national universities. In general, the national universities are viewed as centers for the most significant basic research.

Table 3. Government funding of academic research: 1982

[Percent]

\begin{tabular}{|c|c|c|}
\hline Item & United States & Japan \\
\hline Total .......... & 100.0 & 100.0 \\
\hline $\begin{array}{l}\text { Separately budgeted } \\
\text { academic } \\
\text { research ........ }\end{array}$ & 77.2 & 25.1 \\
\hline $\begin{array}{l}\text { General university } \\
\text { funds }{ }^{1} \ldots \ldots \ldots \ldots\end{array}$ & 22.8 & 74.9 \\
\hline
\end{tabular}

'The United States does not have a system of general university tunds (GUF) like that of Japan and most of Europe Martin and Irvine attempted to identity those U.S R\&.O funds that were similar to GUF in order to distinguish separately budgeted research funds irom those of a more general nature

SOURCE: Ben Martin and John Irvine. An International Comparison of Government Funding of Academic and Academically Related Research (Sussex, England University of Sussex Science Policy Re. search Unit, 1986) 


\section{r\&d by field}

Because the basic infrastructure of Japanese higher education is heavily influenced by private universities in terms of number of institutions, distribution of faculty, and share of student enrollments, the distribution by field of total higher education R\&D expenditures is concentrated in the social sciences, humanities, and other related fields since these are the major areas of instruction and research at private institutions. Consequently, the national patterns of Japanese higher education expenditures reflect the emphasis of private institutions: 40 percent of R\&D expenditures in Japanese higher education are in the social sciences, humanities, and other liberal arts fields (chart 25). ${ }^{29}$ In contrast, the United States expended only 6 percent in social sciences $R \& D$; it does not include liberal arts and related fields in its $R \& D$ data.

Japan's separately budgeted R\&D figures are more comparable to those of the United States because they do not include GUF expenditures, which help to support infrastructure. The share of academic separately budgeted R\&D in Japan going to fields other than the natural and social sciences and engineering was 8 percent in 1982 - a sharp contrast to the 27-percent figure for total higher education $R \& D$. The distribution of separately budgeted R\&D among fields is significantly different in Japan than in the United States. For example, the highest concentration of Japanese separately budgeted funds is in the physical sciences (36 percent compared to 12 percent in the United States); in the United States, concentration is in the life sciences ( 54 percent compared to 26 percent in Japan) (chart 26). Japan

\footnotetext{
${ }^{29}$ More than one-half of the R\&D conducted at private Japanese universities is in fields other than science and engineering, compared with only 22 percent at the national universities.
}

\section{Chart 25. Distribution of total higher education \\ R\&D expenditures among fields: 1985}

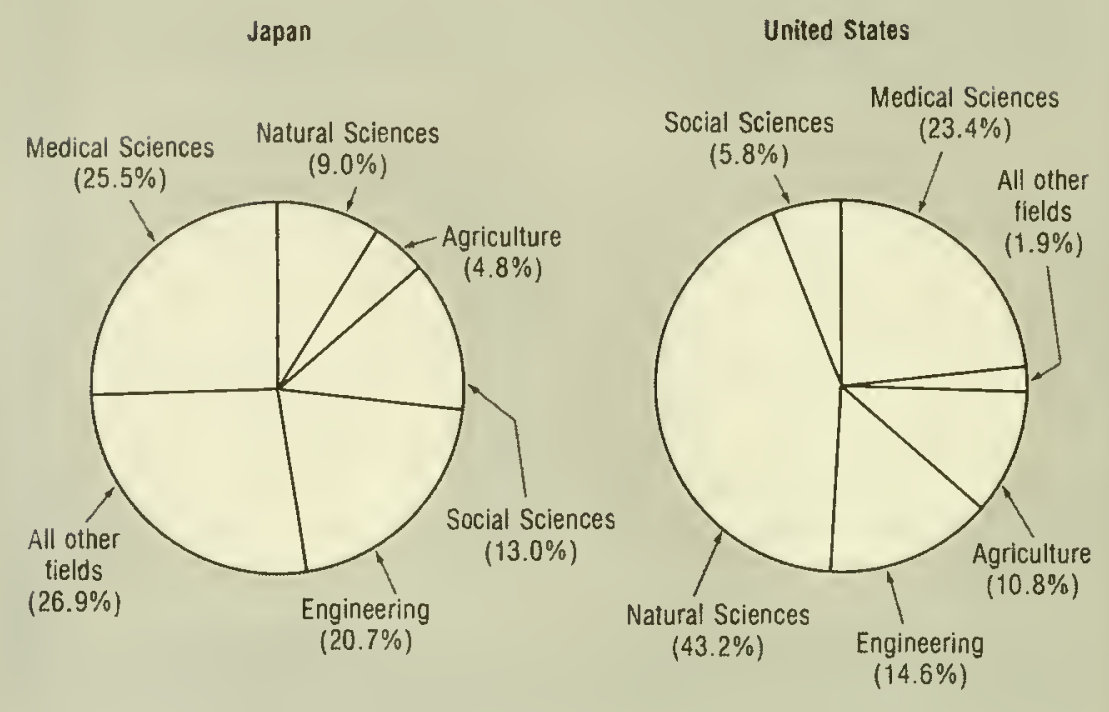

SOURCE: National Science Foundation, SRS, table B-21

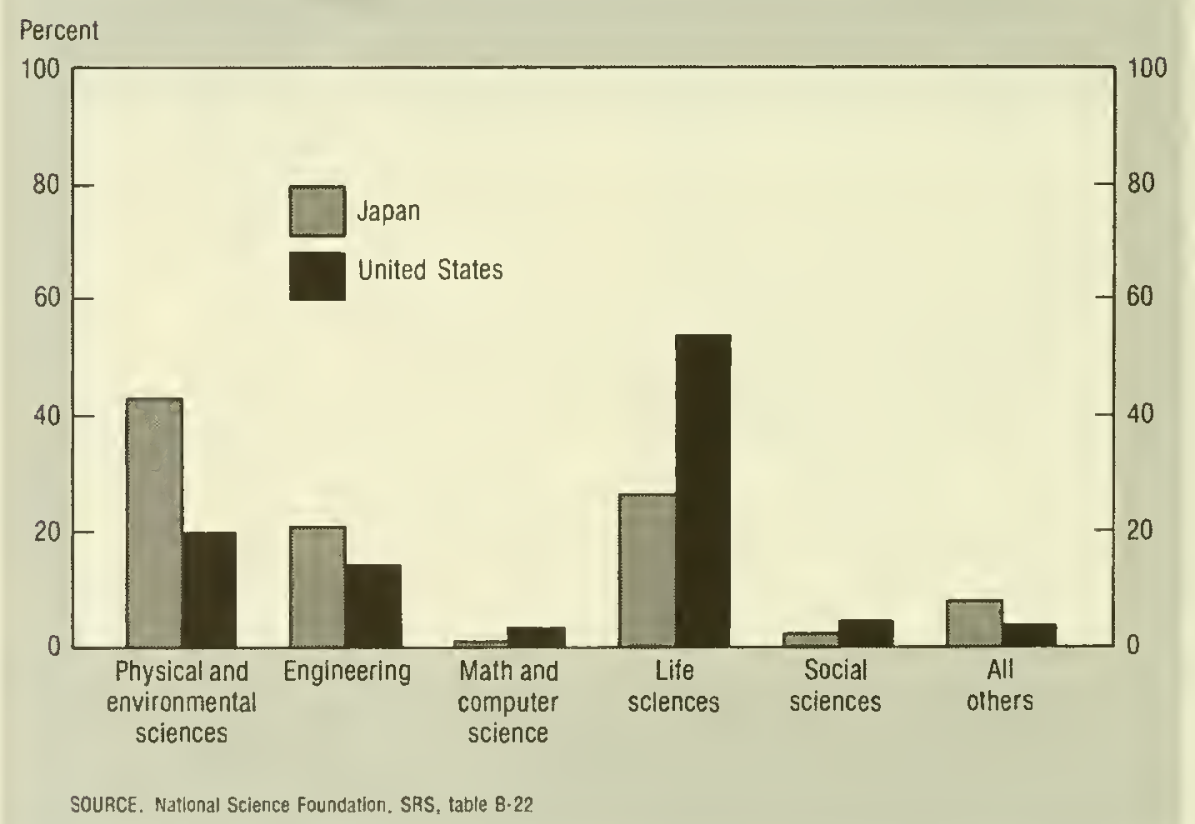


spends about 20 percent of its separately budgeted R\&D on engineering, compared to 14 percent in the United States.

\section{s/e degree production}

The higher education system is by definition responsible for advanced education as well as research. This education is closely coupled with research, especially at the postgraduate level; moreover, the output of trained scientists and engineers is a significant contribution to a nation's S/T capabilities.

Japan's undergraduate education system is one of the largest in the world in proportion to the size of its college-age population. In 1985, the Japanese ratio of all first university degrees as a proportion of the 22year-old population was 22.6 percent, compared to 25.3 percent for the United States (chart 27). The United States confers a significantly higher total number of doctorates than does Japan; however, when the number of doctoral degrees is measured in proportion to the 27 -yearold age group, the overall ratios are close: 0.5 percent for Japan and 0.7 for the United States. The difference is in part due to the higher U.S. proportion of natural sciences doctorates (chart 28). ${ }^{30}$

While Japan's higher education system annually graduates about the same number of first-degree engineers as does the United States, it graduates only about one-tenth as many first-degree students in the natural sciences. The distribution of Japanese first university S/E degrees among fields is dissimilar to that of the United States, but both countries grant about the same relative

\footnotetext{
${ }^{3}$ Note that an increasingly higher proportion of doctorates granted in the United States go to nonU.S. citizens. In 1985, 28 percent of all S/E doctorates were granted to noncitizens; the proportion was 57 percent for engineering doctorates.
}

Chart 27. First-university degrees as a proportion of the 22-year-old population: 1985

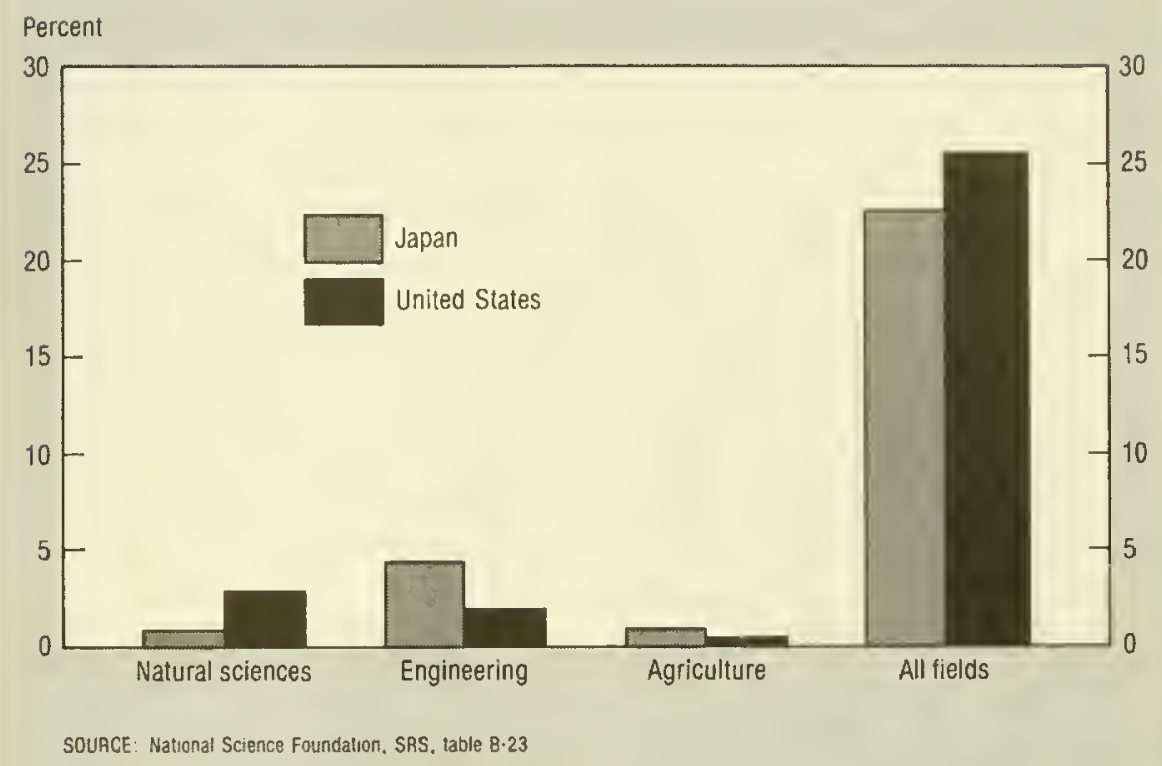

Chart 28. Doctoral degrees as a proportion of the 27-year-old population: 1984 or 1985

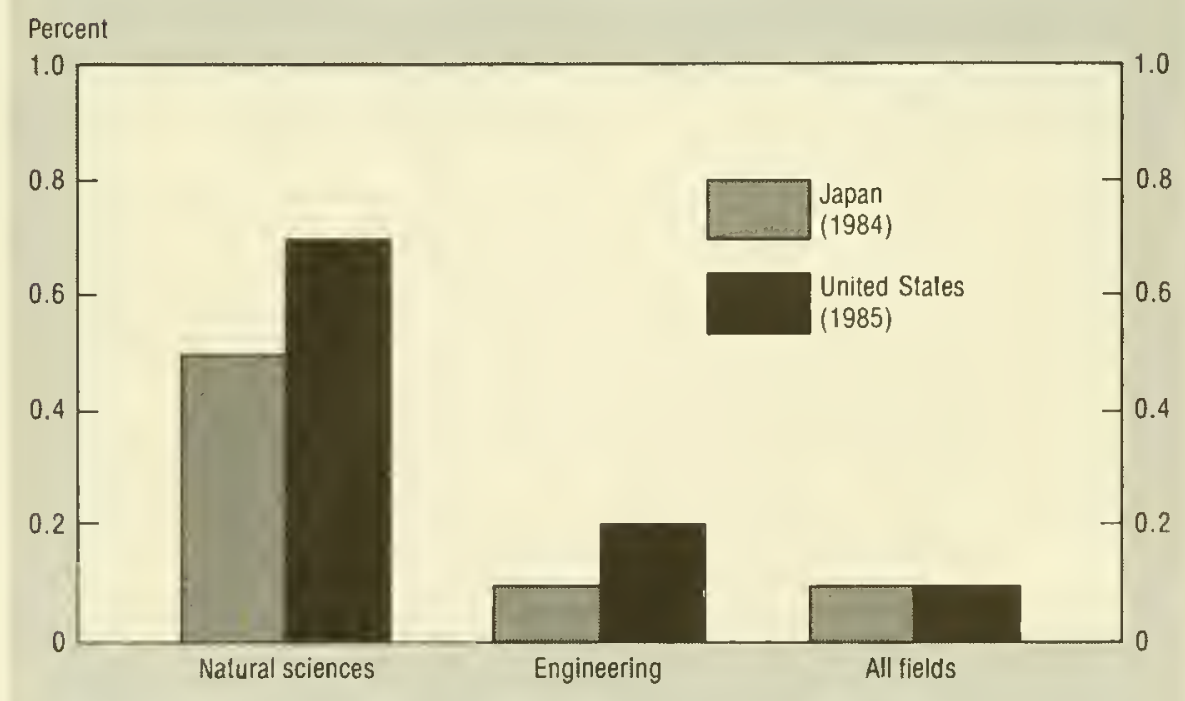

SOURCE, National Science Foundation. SRS, table 8-24 
proportion of degrees in fields other than science and engineering. ${ }^{31}$ Japan grants 19 percent of its first university degrees in engineering (7 percent in the United States) and 3 percent in the natural sciences (11 percent in the United States). Analysis of the career histories of university graduates suggests that many of the graduates of Japan's engineering and agriculture courses assume jobs analogous to those taken on by U.S. science graduates.

With a population size just over one-half that of the United States, Japan in 1976 first exceeded the United States in the granting of firstdegree engineering degrees; it retained this lead through 1982, after which time the number of engineering degrees granted in the United States surpassed that of Japan. (In 1985, the United States conferred 9 percent more engineering degrees than did Japan.) $)^{32}$

\footnotetext{
${ }^{31}$ There are some difficulties in comparing social sciences. In the United States, undergraduate social sciences include a narrow range of specialties; in Japan, the range is broader and includes such fields as commerce and law. Comparisons of the "social sciences" and "all other" categories should be treated with some caution; however, the two categories combined do provide comparable representations of activity in fields other than natural sciences and engineering.

${ }^{32}$ Note the difficulties of cross-national comparisons of numbers and proportions receiving firstdegree engineering degrees. Some maintain that Japanese training in engineering is at a lower level than U.S. training. Most Japanese educators dispute this view, and maintain that Japanese engineering students receive greater exposure to both basic science subjects and laboratory work.
}

While figures on engineering degrees by detailed field are not available for Japan, it is possible to compare enrollments. Both Japan and the United States have about the same shares of engineering enrollments in mechanical and electrical/ computer engineering combined (4952 percent), but greater emphasis is on mechanical engineering in Japan and electrical engineering in the United States. The distributions of enrollments among engineering fields are also generally different (table 4). The actual number of Japanese students enrolled in engineering significantly exceeds U.S. enrollments in the fields of mechanical, chemical, civil, and metallurgical/ materials engineering. U.S. enrollments in electrical and computer and aeronautics/aerospace engineering are much higher than in Japan (the aerospace industry in the United States is much larger than in Japan). One major qualifying factor to these comparisons is that the United States has a much higher proportion of "all other" engineering majors (half of which are undeclared majors) than does Japan (table 4).

Foreign students have traditionally constituted an exceptionally small portion of Japanese undergraduate enrollments (less than 1 percent in 1984); at the graduate level,

\section{Table 4. Enrollments in first-degree engineering programs by field of study:1 1985}

\begin{tabular}{|c|c|c|c|c|}
\hline \multirow[b]{2}{*}{ Field of study } & \multicolumn{2}{|c|}{ Japan } & \multicolumn{2}{|c|}{ United States } \\
\hline & Number & Percent & Number & Percent \\
\hline Total $\ldots .$. & 343,590 & 100.0 & 384,191 & 100.00 \\
\hline Mechanical & 74,354 & 21.6 & 66,738 & 17.4 \\
\hline Electrical and computer & 95,429 & 27.8 & 132,917 & 34.6 \\
\hline 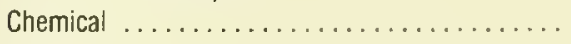 & 39,679 & 11.5 & 23,423 & 6.1 \\
\hline Civil $\ldots \ldots \ldots \ldots \ldots$ & 75,801 & 22.1 & 37,556 & 9.8 \\
\hline Engineering science ... & 5,966 & 1.7 & 7,092 & 1.8 \\
\hline 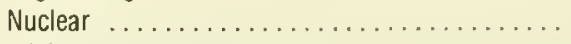 & 1,551 & .5 & 1,857 & .5 \\
\hline Mining $\ldots \ldots \ldots \ldots \ldots \ldots \ldots \ldots \ldots \ldots \ldots \ldots \ldots \ldots \ldots \ldots$ & 1,623 & .5 & 2,431 & .6 \\
\hline Metallurgical and materials... & 7,226 & 2.1 & 3,204 & .8 \\
\hline$\ldots \ldots \ldots \ldots$ & 1,003 & .3 & 2,068 & .5 \\
\hline Aeronautic/aerospace ... & 2,428 & 7 & 15,699 & 4.1 \\
\hline Industrial $\ldots \ldots \ldots \ldots \ldots \ldots \ldots \ldots \ldots \ldots \ldots \ldots \ldots \ldots \ldots$ & 19,829 & 5.8 & 16,434 & 4.3 \\
\hline All others $\ldots \ldots \ldots \ldots \ldots \ldots \ldots \ldots \ldots \ldots$ & 18,701 & 5.4 & 277,781 & 20.2 \\
\hline
\end{tabular}

${ }^{1}$ Full-tıme students only

${ }^{2}$ Hall of this group are undeclared engineering majors

SOURCES Government ot Japan, Ministry of Education, Science, and Culture. Annual School Survey 1984 (Tokyo. Japan, 1985). and Engineering Education (October 1986), o 59 
foreign students in Japan constitute approximately 7 percent of enrollment. In 1984, Monbusho announced a plan to increase the number of foreign students tenfold by the year 2000 . If this occurs, foreign students will constitute approximately 5 percent of all students in Japanese higher education, and possibly one-quarter of all graduate students. Currently, foreign students of Western origin in Japan are most likely to specialize in the humanities and social sciences, while those from Asia and the Third World are most likely to specialize in the sciences and engineering. ${ }^{33}$

\footnotetext{
${ }^{33}$ Factors influencing foreign student enrollments in Japan are discussed in Joseph Hicks, "The Situation of Asian Foreign Students in Japan-Can Japanese Universities Handle a 10-Fold Increase?", Higher Education Expansion in Asu (Huroshima, Japan, Researcl Institute for Higher Education, Hiroshima University, 1985), pp. 141-150.
}

postgraduate education

Postgraduate education is not as strongly emphasized in Japan as in the United States and most of Europe; however, statistics may not fully reflect the number of Japanese receiving some form of postgraduate education. Many of Japan's scientists and engineers leave the university for industrial or other employment immediately upon completion of their first degree. While pursuing a career at a new location, they usually maintain contact with their former professor. If they complete a research project that meets with the professor's approval, they may submit a report as a basis for obtaining a thesis degree.

In Japan, the major constraint on graduate enrollment is the lack of associated employment opportuni- ties. For example, in 1983, 51.0 percent of science and 44.9 percent of agriculture doctoral graduates could not get jobs, but this situation is expected to change. ${ }^{34}$ During the past 2 decades, employment opportunities for engineers with master's degrees have improved: engineering now accounts for 44 percent of all master's degrees granted. At the doctoral level, the most popular fields are medicine and dentistry. Monbusho would like to see more students enrolled in graduate education, and has developed a program that would lead to a threefold increase in master's degree level enrollments and a fourfold increase in doctoral enrollments by the year 2000 .

\footnotetext{
${ }^{34}$ Keiichi Yamada, "Kagukusha Yosei no Arikata Buneki Suru: Ova-Dokuta Mondai, Chushin ni," Shzen, January 1984, pp. 76-83.
} 



\section{chapter 5.}

\section{outputs and impacts}

New knowledge resulting from $R \& D$ is sometimes identifiable by discrete events which can be used as measures of the output of $R \& D$ activity. Scientific literature and patents are two such output indicators. Scientific publications reflect research of significance to the scholarly community; patent registration reflects inventive activity of potential commercial consequence.

The impact of new knowledge resulting from $R \& D$ is more difficult to measure, especially with regard to basic research. R\&D would, however, be expected to have an impact on such economic factors as productivity, demand for technological know-how, and international trade. These factors are, in turn, quantifiable in the form of manufacturing output, royalties and fees, and technology-intensive trade; these can be used as rough measures of the impact of a nation's R\&D efforts.

\section{scientific literature}

The measurable outputs of S/T literature include journal articles, conference papers, technical reports, and literature citations. Conventions for measuring the volume and importance of these various outputs differ among countries, ${ }^{35}$ and Japanesedeveloped indicators for most of the outputs tend to assign higher levels of absolute and relative productivity to Japan than do similar U.S.-developed indicators.

A recent Japanese study by the Mitsubishi Research Institute (MSK)

\footnotetext{
${ }^{35}$ There are a number of reasons for national differences in indicators. Regarding scientific pubjications, for example, U.S. and European researchers use the SCI for many of their analyses. Critics of this data base argue that it (1) overemphasizes science relative to technology, (2) relies on a limited set of the world's influential scientific journals (over 3,500 since 1981 ), and (3) the majority of these pubJications are in English. However, coming from the prestigious, world-class journal set which publishes articles from a variety of countries (country-of-author is assigned at the individual article level), the articles do represent a standard of quality and potential impact. Another benefit of the SCl data base is that it provides citation data with which to measure an article's subsequent usage or impact.

A bibliometric data base has been developed by MSK which includes more than 10,000 journals with greater representation of technology and of nonEnglish journals. The MSK system reviews all articles from this broader base, including those articles which present a minimal level of new data collection and/or original analysis. For more information on MSK study, see footnote 36 in this chapter.
}

estimated the world volume of scientific literature output for the years 1972, 1977, and 1982 and found that the amount of such literature rapidly increased over this 10 -year period. ${ }^{36}$ During 1972-82, the volume of Japanese scientific literature grew at a faster rate than the world total, slightly increasing the Japanese share of each type of literature (table B-25). This growth was most substantial in

\footnotetext{
${ }^{3 h}$ MSK surveyed S/T publications in the fields of mathematics, physics, bıology, geology, medicine, engineering, and agriculture. Data were collected to cover several newly industrializing countries including Korea, Taiwan, Thailand, and Indonesia, as well as the major industrialized nations. For scientific publications, MSK drew from field-specific data bases: Mathfile, INSPEC A for physics, CA Search for chemistry, BIOSIS Preview for biology, GEOREF for geology, Excerta Medica for medicine, COMPENDEX for engineering, and $\mathrm{CAB}$ Abstracts for agriculture. For technical reports, a data base was created from reports listed by the U.S. National Technical Information Service, Britain's System of InternationaJ Gray Literature and severaJ Japanese sources. The principal sources for the conference papers included the Conference Paper Index, ISl's Index to Scientific and Technical Proceedings, Chemical Abstracts, the El Engineering Meeting Bulletin, and JICST's International Conference file. For more detail, see Mitsubishi Sogo Kenkyusko, Kagaku Gijutsu foho no Kokusat-teki Ruutsu no Arikata ni Kansuru (Tokyo, Japan: MSK, March 1981), p. 7ff.
} 
the presentation of conference papers, which nearly quadrupled over the period; and in the output of technical reports, which tripled (chart 29). Although there was a nearly twofold increase in U.S. conference papers, the U.S. share of this literature declined from 45 percent to 41 percent, and there was an absolute as well as relative decline in the number of U.S.-authored technical reports.

According to the Science Citation Index (SCI), Japanese researchers produced 5.1 percent of the world's $\mathrm{S} / \mathrm{T}$ journal articles in 1973 and 7.3 percent in 1982; U.S. shares were 39.2 percent and 37.2 percent, respectively (table 5). By 1984, the Japanese share had increased to 7.6 percent, compared to 36.8 percent for the United States. ${ }^{37}$ The MSK series (see footnote 36) shows a larger Japanese share-10.3 percent in 1973 and 13.1 percent in 1982 - but this difference may be partially ac-

\footnotetext{
${ }^{37}$ These SCI figures are based on a constant 1973 journal set which includes psychology
}

Table 5. Share of world's science and technology articles written by Japanese and U.S. researchers, by field: 1972-73 and 1982

[Percent]

\begin{tabular}{|c|c|c|c|c|c|c|c|c|}
\hline \multirow{3}{*}{ Field } & \multicolumn{4}{|c|}{$\mathrm{SCl}^{\prime}$} & \multicolumn{4}{|c|}{ MSK } \\
\hline & \multicolumn{2}{|c|}{ Japan } & \multicolumn{2}{|c|}{ United States } & \multicolumn{2}{|c|}{ Japan } & \multicolumn{2}{|c|}{ United States } \\
\hline & 1973 & 1982 & 1973 & 1982 & 1972 & 1982 & 1972 & 1982 \\
\hline Agriculture & NA & NA & NA & NA & 11.5 & 11.0 & 31.3 & 33.6 \\
\hline Biology ... & 5.3 & 6.6 & 46.4 & 44.0 & 10.4 & 10.4 & 36.4 & 36.4 \\
\hline Biomedicine & 4.0 & 6.5 & 39.2 & 41.1 & 10.7 & 12.1 & 32.2 & 34.5 \\
\hline Chemistry & 9.4 & 11.6 & 23.3 & 21.9 & 8.3 & 17.9 & 38.3 & 31.6 \\
\hline Clinical medicine & 3.5 & 5.6 & 42.8 & 42.1 & NA & NA & NA & NA \\
\hline Earth and space & 2.0 & 2.1 & 46.7 & 43.1 & 5.0 & 4.3 & 43.0 & 45.1 \\
\hline Engineering. & 5.4 & 7.9 & 41.8 & 41.5 & 13.4 & 13.4 & 36.4 & 36.4 \\
\hline Mathematics & 3.9 & 6.0 & 47.9 & 38.7 & 7.9 & 8.0 & 37.6 & 37.4 \\
\hline Physics & 6.5 & 9.0 & 32.7 & 29.6 & 11.3 & 13.4 & 32.4 & 24.1 \\
\hline All fieldss ${ }^{2}$ & 5.1 & 7.3 & 39.2 & 37.2 & 10.3 & 13.1 & 35.7 & 33.8 \\
\hline
\end{tabular}

'Based on articles, notes, and reviews in a fixed set of about 2,300 journals covered by the Science Citation Index since 1973

includes psychology

NOTE: NA Not separately avallable.

SOURCES SCI data from Computer Horızons, Inc. unpubished findings, MSK from Mitsubıshı Sogo Kenkyusho, Kagaku Gijitsu Joho no Kokusar-tekı Ryutsu Arkkala ni Kan-suru (Tokyo. Japan MSK, March 1984), p 12

counted for by the more select range of journals covered by $\mathrm{SCl}$, which has fewer journals in the fields of engineering and agriculture.

Although the MSK data show considerably higher Japanese and slightly lower U.S. shares of the scientific literature, both data sets gen-

\section{Chart 29. Trends in scientific literature outputs}
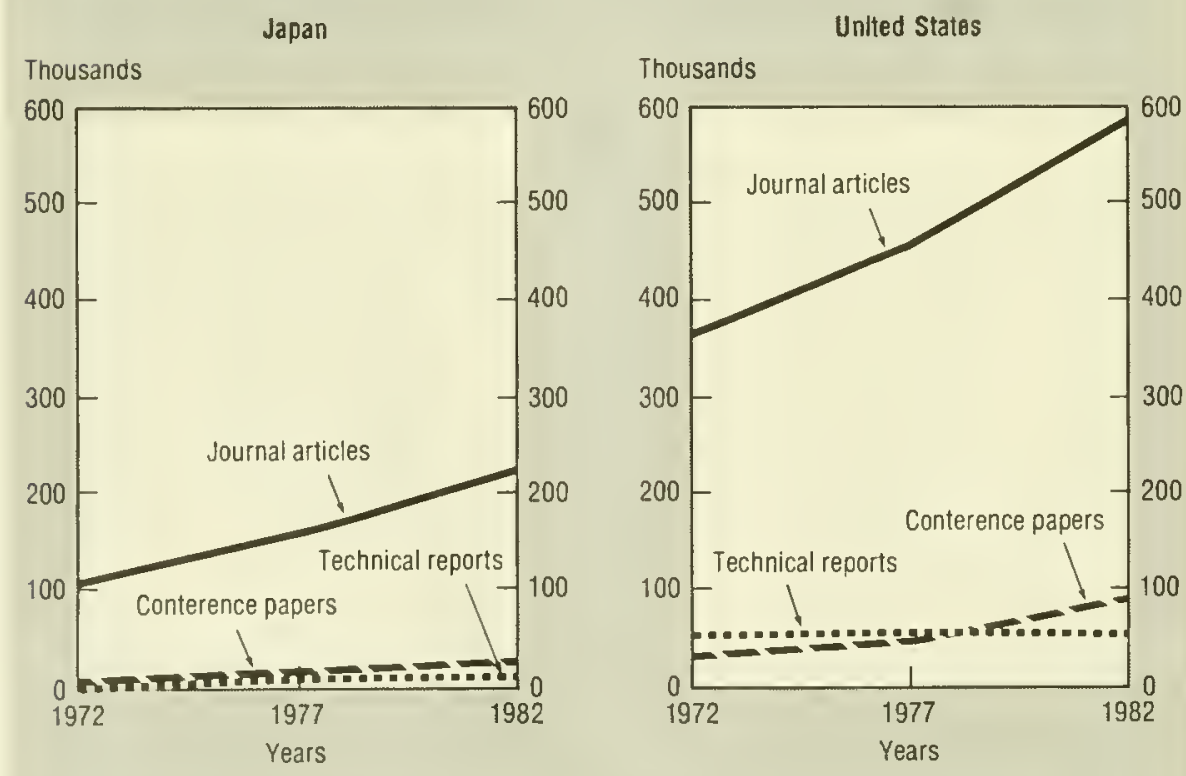

SOURCE National Science Foundation. SRS, table B-25 erally reflect similar trends and distributions among fields. Both sources indicate that Japanese researchers' shares of publications are largest in the fields of chemistry, engineering, and physics; and lowest in the earth and space sciences. Both also indicate that the U.S. share of the world's scientific literature slightly declined from 1972 to 1982 by 2 percentage points.

According to the $\mathrm{SCl}$ data, the Japanese share of $\mathrm{S} / \mathrm{T}$ articles during the 1973-82 period was greatest in the pharmacy subfield, with Japanese publications accounting for 25 percent of the articles written in that subfield (table 6). The next largest shares were in polymers (18 percent) and marine biology and hydrobiology (14 percent).

Journal citation rates are one measure of the quality of articles being published. On this indicator, Japanese authors have done slightly less well than expected overall, but have improved significantly over the 197383 period and performed strongly in the engineering subfield. Using share of total citations to share of total papers as a relative citation indicator, a value of 1.0 reflects expected performance: articles are being cited at the same rates at which they are 
Table 6. Japan's share of world science and technology articles, by selected subfield: 1 1973-82

\begin{tabular}{|c|c|}
\hline Subfield & Percent \\
\hline Pharmacy & 25 \\
\hline Polymers..$\ldots \ldots \ldots \ldots \ldots \ldots$ & 18 \\
\hline Marine biology and hydrobiology .... & 14 \\
\hline General chemistry .............. & 13 \\
\hline $\begin{array}{l}\text { Electrical engineering and } \\
\text { electronics. . . . . . . }\end{array}$ & 12 \\
\hline Applied physics ......... & 12 \\
\hline Agriculture and food science ....... & 11 \\
\hline Microscopy ............. & 11 \\
\hline Organic chemistry & 10 \\
\hline General physics ............... & 10 \\
\hline Analytical chemistry $\ldots \ldots \ldots \ldots$. & 10 \\
\hline Embryology ................. & 10 \\
\hline Nuclear technology ....... & 10 \\
\hline
\end{tabular}

'Subtields in which Japanese articles represented 10 percent or more of subtield Data are from a tixed set of about 2,300 pournals covered by the Science Crtation Index since 1973

SOURCE: Francis Narın and Dominic Olivastro. Aclivity Analysis Using SIC Categorres and Scientific Subfields, interm report by Computer Horizons. Inc., to the National Science Foundation, May 1986

published. On this basis, total Japanese-authored articles have slightly less of an impact than would be expected-in 1983, the relative citation ratio for all Japanese articles was 0.91 . $^{38}$ However, this ratio was up significantly from its 1973 level of 0.77 , and in engineering it increased from 0.76 in 1973 to 1.25 in 1983 . In comparison, the U.S. citation ratio for all articles was 1.36 in 1973 and 1.34 in 1983.

\section{patent indicators}

Patents are often considered an indicator of the vigor of individual scientists and engineers, corporations, or nations in developing new products and processes. However, national practices regarding domestic patent applications and grants often make comparisons of absolute numbers of patents problematic. For example, in Japan and Germany both

\footnotetext{
${ }^{38}$ See Francis Narin and Dominic Olivastro, Identifying Areas of Leading Edge Japanese Science and Technology, Final Report to the National Science Foundation, Division of Science Resources Studies, April 1988, p. 170.
}

actual inventions and practical designs are acceptable as the basis for a patent application; in the United States, the more stringent criterion of actual invention customarily is required for a patent application. Also, in some countries (including Japan), patent applications are viewed as a key indicator of a laboratory's productivity. Under such circumstances, and especially when the cost for submitting a domestic application is modest, companies may submit a number of applications for inventions that have little likelihood of ever being implemented. ${ }^{39}$

On the other hand, since submitting applications to foreign countries is more costly, companies usually make foreign applications only for those inventions that are genuinely believed to have commercial value in the foreign market. Based on this tendency, comparisons of patent applications abroad can indicate the most important or potentially profitable inventions.

Japan accounts for the largest share of foreign-origin patents in the U.S. patent system. Analysis of Japanese-invented U.S. patents granted between 1970 and 1986 demonstrates substantial Japanese patenting activity: during the period, the share of U.S. patents annually granted to the Japanese increased from 4 percent to 19 percent. As shown in table 7, the Japanese share of patents by SIC category also has risen dramatically. In 1975, Japanese-origin patents accounted for 9 percent of U.S. patents granted for all SIC categories; by 1985, this share had doubled to 19 percent. In most SIC categories, the Japanese share of total patents granted was nearly

\footnotetext{
${ }^{39}$ The standard legal text comparing internationa patent systems is John P. Sinnott, World Patent Law: Patent Statutes, Regulations, and Treaties (New York, New York: Matthew Bender \& Co., Inc., 1974), and is updated annually. See also Stephen Ladas, $P a-$ tents, Trademarks, and Related Rights; National and International Protection (Cambridge, Mass.: Harvard Univ. Press, 1974). Note that there have been recent changes in Japanese patent law, including the removal of single-claim restrictions.
}

\section{Table 7. Japanese-invented U.S. patents by SIC category: 1975 and 1985}

[Percent]

\begin{tabular}{|c|c|c|}
\hline \multirow[b]{2}{*}{ SIC category } & \multicolumn{2}{|c|}{$\begin{array}{c}\text { Share of total } \\
\text { patents } \\
\text { granted }\end{array}$} \\
\hline & 1975 & 1985 \\
\hline Food & 8 & 11 \\
\hline Textiles ........... & 10 & 17 \\
\hline $\begin{array}{l}\text { Chemicals and allied } \\
\text { products. . . . . . . }\end{array}$ & 10 & 15 \\
\hline Petroleum ........ & 3 & 6 \\
\hline Rubber ... & 10 & 18 \\
\hline Ceramics $^{1}$. & 8 & 20 \\
\hline Primary metals ............ & 13 & 23 \\
\hline Fabricated metals .......... & 5 & 12 \\
\hline General machinery .......... & 7 & 15 \\
\hline $\begin{array}{l}\text { Office computing and } \\
\text { accounting machines }{ }^{2}\end{array}$ & 13 & 33 \\
\hline Electrical machinery ......... & 10 & 21 \\
\hline $\begin{array}{l}\text { Communications equipment } \\
\text { and electronic components }\end{array}$ & 13 & 26 \\
\hline Motor vehicles $\ldots \ldots \ldots \ldots$. & 7 & 23 \\
\hline Aircraft and parts .......... & 10 & 30 \\
\hline $\begin{array}{l}\text { Professional and scientitic } \\
\text { instruments } \ldots \ldots \ldots \ldots\end{array}$ & 12 & 23 \\
\hline All fields $\ldots \ldots \ldots \ldots \ldots$ & 9 & 19 \\
\hline
\end{tabular}

'Stone, clay, and glass products.

IIncludes computers.

SOURCE Office of Technology Assessment and Forecast, U S Patent and Trademark Office, unpublıshed data

20 percent or more; the shares were highest in the office computing machinery (33 percent), aircraft and parts (30 percent), and communications equipment and electronic components ( 26 percent) category.

In terms of patent class (as opposed to SIC group), Japanese patenting activity during 1975-84 was concentrated in the internal combustion engines, radiation imagery, and photography patent classes; more than 2,000 patents were granted in each of these three classes during the 1975-84 period (table B-26). The Japanese shares were highest in the photography (53 percent), dynamic magnetic information storage (38 percent), photocopying (36 percent), and radiation imagery (35 percent) patent classes.

Table 8 indicates several technology areas in which Japanese patenting activity has been especially vigorous. In all technological areas, 
Table 8. U.S. and Japanese shares of total patents granted in the United States for selected technologies: 1975 and 1986

[Percent]

\begin{tabular}{|c|c|c|c|c|}
\hline \multirow[b]{2}{*}{ Selected technologies } & \multicolumn{2}{|c|}{ United States } & \multicolumn{2}{|c|}{ Japan } \\
\hline & 1975 & 1986 & 1975 & 1986 \\
\hline Lasers & 63 & 50 & 14 & 35 \\
\hline Telecommunications & 66 & 52 & 14 & 26 \\
\hline Steel and iron .... & 48 & 37 & 18 & 29 \\
\hline Internal combustion engines & 54 & 28 & 17 & 44 \\
\hline Semiconductor devices and manufacture & 68 & 57 & 13 & 29 \\
\hline Jet engines ....................... & 66 & 60 & 4 & 9 \\
\hline General purpose programmable digital computer systems & 77 & 69 & 5 & 19 \\
\hline Robots $\ldots \ldots \ldots \ldots \ldots$ & 63 & 50 & 20 & 29 \\
\hline Machine tools-metalworking & 65 & 51 & 8 & 17 \\
\hline All technologies .......... & 65 & 54 & 9 & 19 \\
\hline
\end{tabular}

SOURCE Office of Technology Assessment and Forecast, US Patent and Trademark Office, unpublished dala

Japan's share of U.S. patents granted has increased. The largest gains have been in internal combustion engines, which rose from 17 percent of the patents granted in 1975 to 44 percent in 1986; and lasers, which rose from 14 to 35 percent. Other technological areas of extensive Japanese patenting activity are semiconductors, computer systems, and machine tools.

Japanese-origin patents are also among the most highly cited U.S. patents; in fact, Japan has one-third more of highly cited patents than expected based on the total number of U.S. patents granted to Japanese inventors. Citations to earlier relevant patents are assigned by U.S. patent examiners to new patents, and as such, define the boundaries of the technology preceding and contributing to the new invention. A high number of patent citations-repeated references to a technological predecessor of a new patent-is (essentially) the indicator of a very significant invention. For the top 1 percent of the most highly cited U.S. patents, Japanese patents account for 45 percent more of the top 1 percent, most highly cited U.S. patents than expected. The highest citation rates for Japanese patents are in the automotive, semiconductor electron-

\section{industrial productivity}

Recent assessments ${ }^{41}$ of Japanese technology have observed that one of Japan's strengths has been in applying technology to production processes. One study indicates that Japanese industries invest their R\&D much more heavily in improved process technology than do their U.S. counterparts, and notes that "process $R \& D$ tends to have a bigger effect on an industry's own rate of productivity increase than does product R\&D." 42

Japan has made rapid progress in manufacturing productivity during the past decade; manufacturing output per worker-hour increased 68 percent from 1977 to 1986 , compared with a 26-percent increase in the United States for the same period (chart 30). In recent years, U.S.

\footnotetext{
'See, for example, Lowell W. Steele and N. Bruce Hannay, The Competitive Status of U.S. Industry: An Overnew (Washington, D.C.: National Academy Press, 1985).

${ }^{42}$ Edwin Mansfield, Industrial RED in Japan and the United States: A Comparative Study, unpublished paper, 1987.
}

No Narin and Olivastro, op. cit

\section{Chart 30. Output per worker hour in manufacturing [Index: $1977=100$ ]}

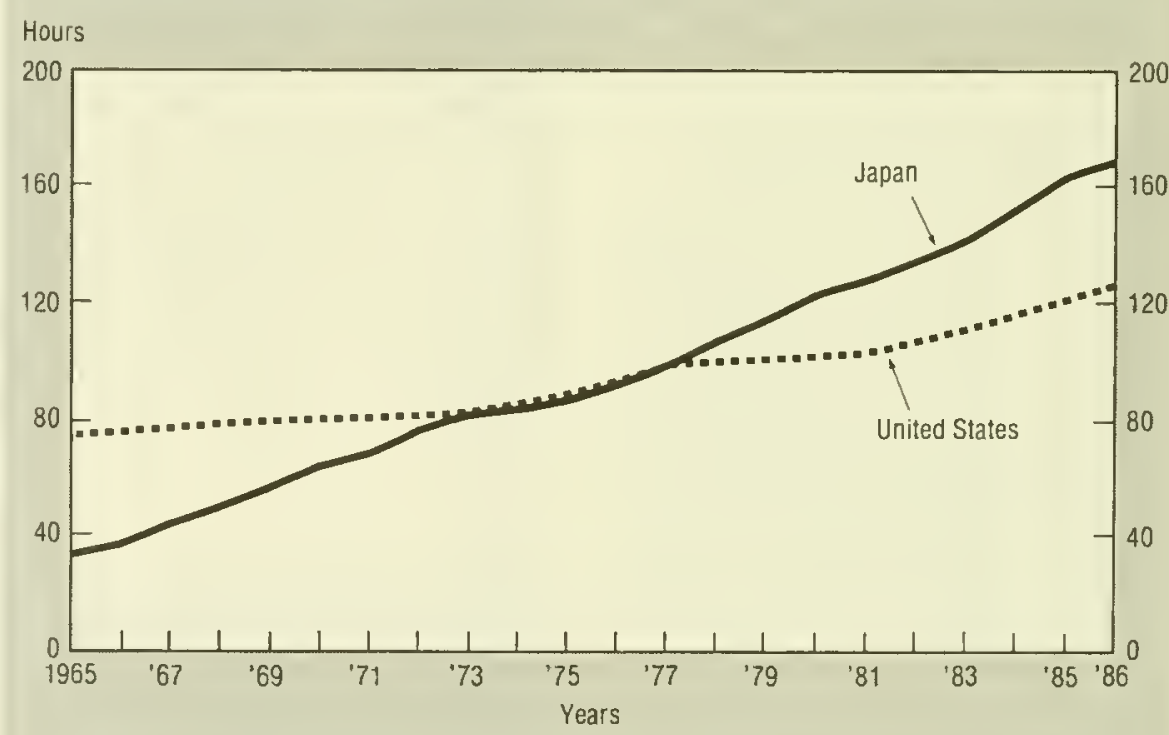

SOURCE. National Science Foundatlon. SRS, table B-27 
manufacturing productivity has increased more rapidly (at an average annual rate of about 4 percent from 1980 to 1986) than in the late 1970's; this still has not been as fast as Japan's (which increased at an average annual rate of about 6 percent from 1980 to 1986). Although Japan started from a lower absolute productivity base in the fifties and sixties, a recent Japanese study indicates that Japanese levels of actual valueadded per worker equaled or surpassed the U.S. level in several key industries-including autos and steel-by 1980 , primarily because of the rapid productivity gains made during the seventies. ${ }^{43}$

\section{royalties and fees}

National trends in technology transfer. Data on international transactions in royalties and fees are often used as indicators of technology transfer and demand for commercially attractive technology. Royalties and license fees are payments for the use of intellectual property, including patents, inventions or processes, copyrights, etc. Although data on royalties and fees are only partial measures of technology transfer, they do provide information on the direction of technology flows.

Data on international receipts and payments for technical know-how for Japan and the United States demonstrate the major differences between these two countries. The United States is a net exporter of technology whereas Japan is a net importer, and Japan purchases far more technical know-how from the United States than the United States does from Japan. Although Japan's technological balance of payments

\footnotetext{
${ }^{43}$ Kazukiyo Kurosawa, Intermational Comparison of Productivity, Paper presented to the International Productivity Symposium, May 11, 1983 (Tokyo, Japan).
}

worsened in dollar terms from a deficit of constant $\$ 1.2$ billion in 1970 to constant $\$ 1.7$ billion in 1985, receipts as a share of payments improved, rising from 14 percent to 30 percent. This indicates a possible shift in Japan's dependence on imported technology, an increase in the salability of Japanese technology, and/ or a greater willingness by the Japanese to sell their technology. In 1970, Japan received constant $\$ 194$ million in payments for its technology; this increased to constant $\$ 721$ million by 1985 (chart 31). Most Japanese technical know-how sales are to newly industrializing countries; most purchases are from industrialized nations. In 1985, 42 percent of Japan's sales and 99 percent of its purchases were with the United States and Europe (table 9). East Asian countries also purchase a significant share of Japanese technology-nearly 40 percent in 1975 and 1985. Sales to the United States increased from 10 percent in 1975 to 22 percent in 1985; payments also increased, rising from 63 percent to 71 percent.

Manufacturing technology transfer. A review of national patterns indicates that Japan invests heavily in foreign technology. Over the past decade, however, Japan's industrial expenditures on foreign technology relative to other indicators have decreased, as Japan's performance on two technical deperıdency indicators shows. First, payments for technical know-how as a percentage of

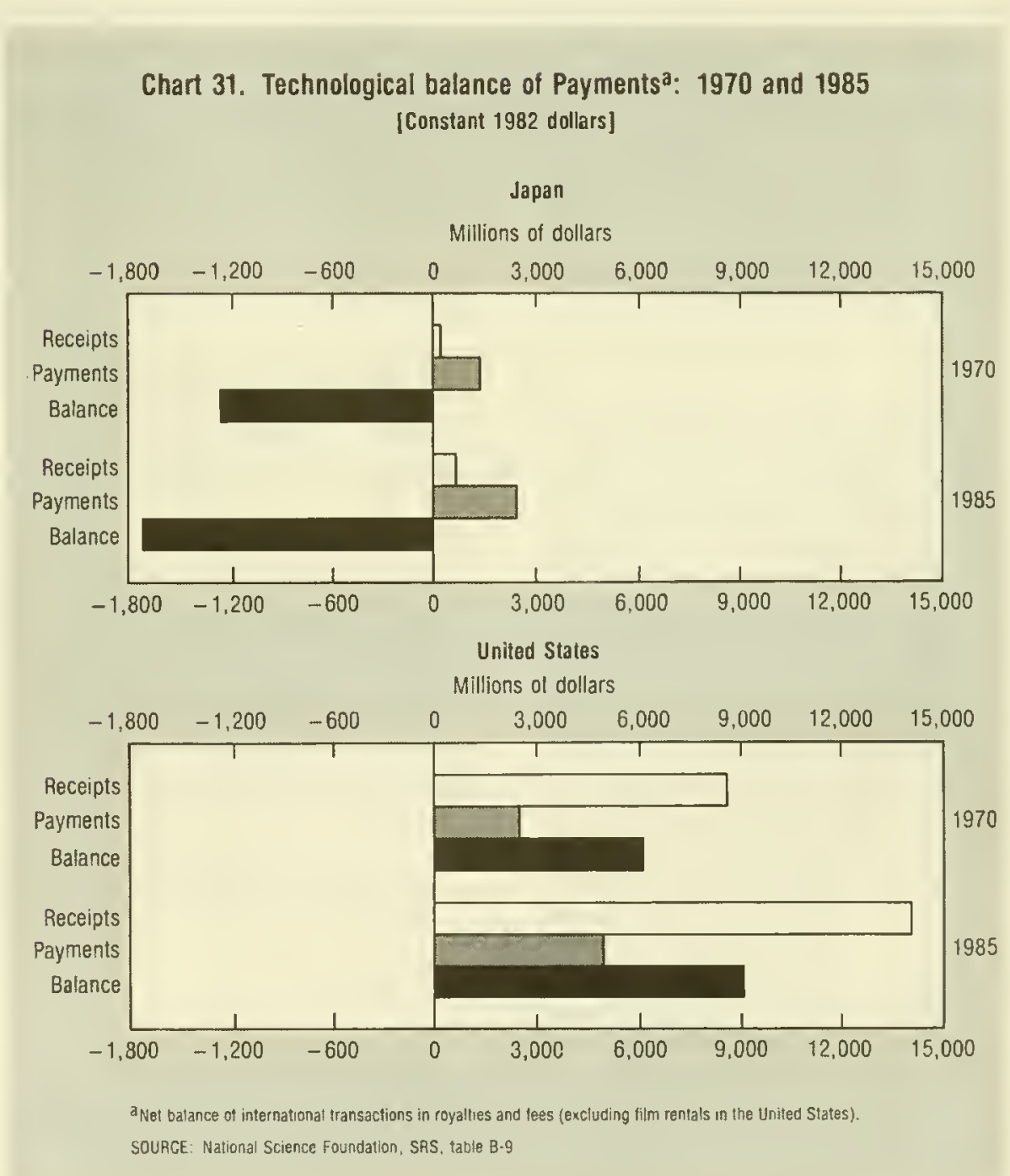


Table 9. Japanese receipts and payments for technical know-how, shares by country: 1975 and 1985

[Percent]

\begin{tabular}{|c|c|c|}
\hline Receipts and payments & 1975 & 1985 \\
\hline $\begin{array}{l}\text { Receipts from: } \\
\text { Total ......... }\end{array}$ & 100.0 & 100.0 \\
\hline $\begin{array}{l}\text { United States ........ } \\
\text { Europe ........... } \\
\text { South America ....... } \\
\text { East Asia .......... } \\
\text { All other countries .... }\end{array}$ & $\begin{array}{r}10.4 \\
21.1 \\
8.8 \\
39.2 \\
20.5\end{array}$ & $\begin{array}{r}22.1 \\
19.4 \\
3.7 \\
37.4 \\
17.4\end{array}$ \\
\hline $\begin{array}{l}\text { Payments to: } \\
\text { Total } \ldots \ldots \ldots \ldots \ldots\end{array}$ & 100.0 & 100.0 \\
\hline $\begin{array}{l}\text { United States } \ldots \ldots \ldots \\
\text { Europe } \ldots \ldots \ldots \\
\text { All other countries ..... }\end{array}$ & $\begin{array}{r}63.1 \\
35.4 \\
1.5\end{array}$ & $\begin{array}{r}71.2 \\
27.8 \\
1.0\end{array}$ \\
\hline
\end{tabular}

SOURCE- Government of Japan, Scrence and Technology Agency

$R \& D$ expenditures declined significantly from 1975 to 1985 for all manufacturing industries except ceramics (which increased by 1 percentage point) and food processing (which remained the same) (table B-28). ${ }^{44}$ In 1975, the ratio of payments to $R \& D$ for all manufacturing industries was 11 percent; in 1985, 5 percent. By

\footnotetext{
"4 There are two series of data available for Japanese technology transfer. One series is provided by the Bank of Japan and the other by the Government's Statistics Bureau, and there are some major differences between the two series. The Bank of Japan data are on all economic sectors (government, services, etc.), and reflect only transactions involving the payment of royalties and fees. Statistics Bureau data are derived from the annual $R \& D$ survey (see appendix A, "Technical Notes") and on the industrial sector only. Additionally, the Statistics Bureau data include not only royalties and fees, but services and sales of whole manufacturing plants if technology is transferred in the transaction. The consequence is that the Statistics Bureau data show a higher volume of technology exports ( 32 percent higher in 1985) and a lower volume of imports (51 percent lower in 1985) than do Bank of Japan data.

The data discussed in this section are from the Statistics Bureau, as disaggregated manufacturing data are not available from the Bank of Japan (the Bank of Japan royalties and fees data are presented in chapter 1, "National Patterns"). For more information on technology transfer data from Japan, see Leonard H. Lynn, "Technology Transfer to Japan: What We Know, What We Need to Know, and What We Know That May Not be So," in Nathan Rosenberg and Claudio Frischtak, eds., International Technology Transfer: Concepts, Measures, and Comparisons (New York, New York: Praeger, 1985), pp. 255-276.
}

1985, in no industry other than ceramics did Japanese purchases of technical know-how exceed 8 percent of the respective industry's $R \& D$ expenditures, and in most industries this ratio was 5 percent or less.

As Japanese industry's overall dependence on foreign technology appears to have decreased over the past decade, some interesting industrial patterns have emerged. For several industries (textiles, chemicals, iron and steel, and motor vehicles), the technology know-how receipt to payment ratio exceeded 100 percent in 1985 while real payments for technology declined or remained the same: this indicates that the attractiveness of Japanese science and technology in these areas is increasing. In fact, for the iron and steel industry, receipts for Japanese technical know-how exceeded Japanese payments by almost 6 to 1 . The receipt to payment ratio for all Japanese manufacturing industries was 36 percent in 1975 and 72 percent in 1985, and was about 50 percent or higher for most industries by 1985 (table B-28).

\section{technology trade}

National R\&D efforts are often associated with changing positions in world trade. Comparative experience indicates that there is not a oneto-one relationship between $R \& D$ efforts and trade performance; rather, a more indirect effect exists because of the large number of variables affecting international trade. ${ }^{45}$ Success in international trade is only partially dependent on having a good

${ }^{45}$ Raymond Vernon, Then Technology Factor in International Trade (New York, New York: National Bureau of Economic Research, 1970); and Sherman Gee, Technology Transfer, Innovation, and International Competition (New York, New York: John Wiley and Sons, 1981) innovation; products have to be produced efficiently and marketed effectively to have an impact on trade. In addition, international differences in costs of production, trade barriers, and exchange rates can adversely affect the sales of otherwise attractive products.

Given these caveats, it has nevertheless been shown that $R \& D$ and technological innovation do play a major role in trade performance ${ }^{46}$ Japan has improved its position in international trade in tandem with its $R \& D$ expansion to such a degree that Japan's improved trade position with the United States has been a salient political issue for several years. Japanese technology-intensive trade with the United States has also markedly improved over the 196585 period. The Japanese trade surplus with the United States in technology-intensive ${ }^{47}$ goods increased from current $\$ 143$ million in 1965 to current $\$ 13$ billion in 1985 (chart 32). Large trade surpluses existed in 1985 in radio and television receiving equipment, communications equipment, office and computing machines, and professional and scientific instruments. On the other hand, however, Japan had a negative trade balance in aircraft and parts, industrial inorganic chemicals, drugs, and agricultural chemicals (table 10). Japan has increased its world share of technology-inten-

\footnotetext{
${ }^{4} 6 \mathrm{See}$, for example, both Vernon and Gee, op, cit. Also see Rachel McCulloch, Research and Development as a Determinant of U.S. International Competitiveness (Washington, D.C.: National Planning Association, 1978); and Regina K. Kelly, The Impact of Technological Innovation on International Trade Patterns, Paper presented at the Conference on Government Industry Cooperation in Technological Innovation (Geneva, Switzerland, June 1977).

${ }^{47}$ There is no universally accepted definition of technology-intensive products. The definition used here is one that was adopted by the Organisation for Economic Co-operation and Development and the U.S. Department of Commerce (DOC2 definition): technology-intensive products are those products for which U.S. R\&D expenditures exceed 2.36 percent of sales. See table 10 for a list of the product fields included.
} 


\section{Chart 32. Japanese trade balance with the United States in technology-intensive products ${ }^{\mathrm{a}}$ \\ [Current dollars]}

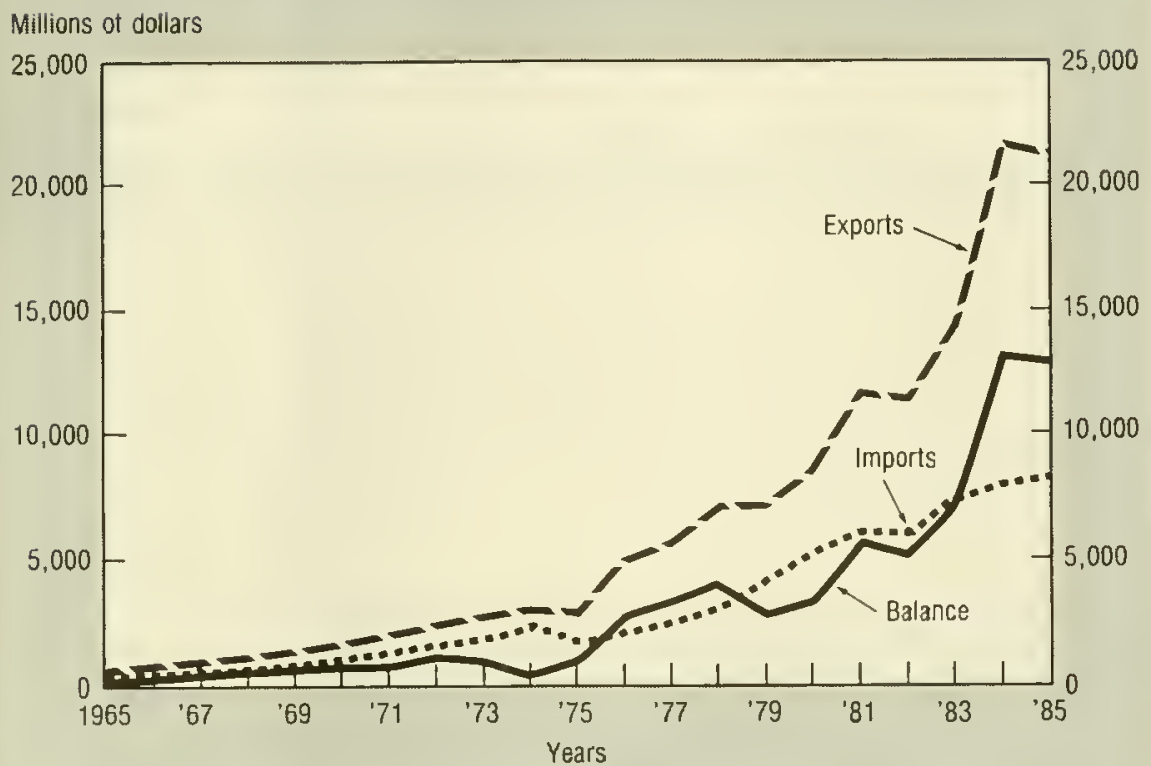

aThose products lor which U.S R\&D expenditures exceed 236 pefcent of value-added (DOC-2/Organisation for Economic Co-operation and Development delınition)

SOURCE: National Science Foundatuon, SRS, table 8-29

\section{Table 10. Japanese trade with the United States in technology-intensive products: 1985}

\begin{tabular}{|c|c|c|c|}
\hline Product group & Balance & $\begin{array}{l}\text { Exports to } \\
\text { United States }\end{array}$ & $\begin{array}{l}\text { Imports from } \\
\text { United States }\end{array}$ \\
\hline Total & $13,024.0$ & $21,252.2$ & $8,228.1$ \\
\hline Aircraft and parts & $-1,931.1$ & 113.0 & $2,044.1$ \\
\hline Industrial inorganic chemicals & -886.4 & 116.7 & $1,003.1$ \\
\hline Radio and TV receiving equipment & $5,919.3$ & $5,925.9$ & 6.6 \\
\hline Office and computing machines. & $2,915.8$ & $4,101.5$ & $1,185.7$ \\
\hline Electrical machinery and equipment & 713.4 & $1,922.1$ & $1,208.6$ \\
\hline Communications equipment & $3,139.6$ & $4,064.8$ & 925.2 \\
\hline Professional and scientific instruments & $2,660.0$ & $3,270.6$ & 610.6 \\
\hline Drugs $\ldots \ldots \ldots \ldots \ldots \ldots \ldots \ldots \ldots \ldots \ldots \ldots \ldots \ldots \ldots \ldots \ldots$ & -450.0 & 94.7 & 544.7 \\
\hline Plastic materials and synthetics $\ldots \ldots \ldots \ldots \ldots$ & 2.3 & 472.1 & 469.8 \\
\hline Engines and turbines $\ldots \ldots \ldots \ldots \ldots$ & $1,027.0$ & $1,155.0$ & 128.0 \\
\hline Agricultural chemicals & -85.8 & 15.7 & 101.6 \\
\hline
\end{tabular}

'Technology-intensive products are defined as those for which US R\&O expenditures exceed 236 percent of sales (US Department of Commerce DOC2 and Organisation for Economic Co-0peration and Development definition) Data reflects information from 24 reporting countries on exports to. and imports from, each of nearly 200 partner countries

SOURCE. Natıonal Science Foundation, DRI Special Tabulatıons of Internatıonal Trade, 1987

sive trade from 7 percent in 1965 to 19 percent in 1985, while the U.S. share declined from 28 percent to 24 percent (chart 33). Japan's share of technology-intensive imports remained extremely stable throughout the 20-year period at about 5 percent.
In 1985, high-technology products accounted for 53 percent of U.S. manufactures exports to Japan and 35 percent of U.S. imports of Japanese-manufactured goods. ${ }^{48}$ The U.S. deficit in high-technology trade increased fivefold from 1980 to 1986, growing from current $\$ 3.8$ billion to $\$ 21.9$ billion (table 11$){ }^{49}$ According to the Department of Commerce, telecommunications equipment and electronic components accounted for about 75 percent of the high-technology trade deficit. Over the 198185 period, the rising deficit in this class constituted nearly 66 percent

\footnotetext{
${ }^{48} \mathrm{High}-\mathrm{tech} n \mathrm{log} y$ trade includes fewer (and slightly different) product categories than technology-intensive trade because it accounts for the R\&D contribution of upstream inputs (U.S. Department of Commerce DOC3 definition)

${ }^{49}$ U.S. Department of Commerce, United States Trade: Performance in 1985 and Outlook (Washington D.C.: Supt. of Documents, U.S. Government Printing Office, 1986), p. 79.
} 
Chart 33. World export shares of technology-intensive products ${ }^{\mathrm{a}}$

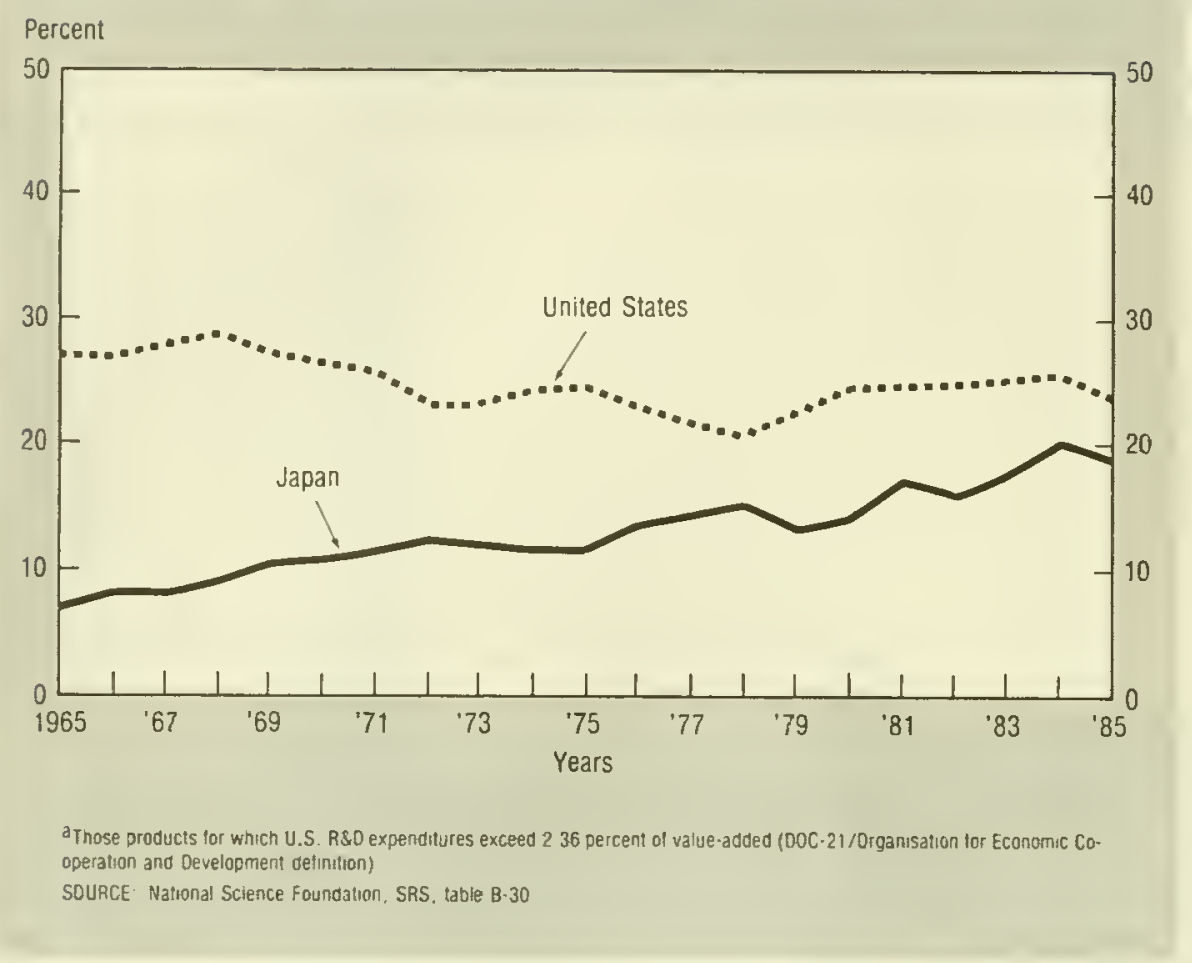

of the total increase in the high-technology trade deficit. Within hightechnology trade, the U.S. runs surpluses in the aircraft and parts,

Table 11. U.S. trade with Japan in high-technology' manufactured products: $1980-86$

[Current dollars in billions]

\begin{tabular}{|c|c|c|c|}
\hline Year & Balance & $\begin{array}{l}\text { Exports to } \\
\text { Japan }\end{array}$ & $\begin{array}{l}\text { Imports } \\
\text { from } \\
\text { Japan }\end{array}$ \\
\hline $\begin{array}{l}1980 \ldots \\
1981 \ldots \\
1982 \ldots \\
1983 \ldots \\
1984 \ldots \\
1985 \ldots \\
1986 \ldots\end{array}$ & $\begin{array}{r}S-3.8 \\
-5.9 \\
-6.4 \\
-8.8 \\
-16.0 \\
-18.6 \\
-21.9\end{array}$ & $\begin{array}{r}\$ 4.1 \\
4.9 \\
4.8 \\
5.6 \\
6.1 \\
6.6 \\
7.6\end{array}$ & $\begin{array}{r}\$ 7.8 \\
10.7 \\
11.3 \\
14.4 \\
22.2 \\
25.2 \\
29.4\end{array}$ \\
\hline
\end{tabular}

'High-lechnology products are those U S products that embody significanily more A\&O than other products (U S Oepartment of Commerce DOC3 definition) High-technology trade includes tewer (and sightly different) product categories than technology-intensive trade because it accounts for the R\&O contnbution of upstream inputs

SOURCE U S Oepartment ol Commerce. Unired States Irade. Performance in 1985 and Outlook (Washington, $0 \mathrm{C}$ Supt of Documents. US Govemment Printing Office. October 1986), and unpublished data
On a worldwide basis, Japan has

product dominance in the radio and pharmaceuticals, and industrial inganic chemicals categories. television receiver equipment trade, accounting for 78 percent of world exports in 1985 (table 12). It also has large shares of the world's trade in communications equipment (37 percent) and professional and scientific instruments ( 30 percent); the United States has large shares of world trade in aircraft and parts (51 percent), office and computing equipment (33 percent), and agricultural chemicals (31 percent).

Overall, Japan has shown an impressive performance in technology outputs and impacts. During the 1975-85 period, the share of U.S. patents held by the Japanese doubled; furthermore, patent citation data suggest that not only are the number of Japanese-origin patents increasing, but that-in particular product classes-they also represent highly influential inventions. Similarly, trends in technology-intensive and high-technology trade reflect the expanded $R \& D$ and other efforts of Japan over the last few decades, although the outputs of scientific research as measured by the two bibliometric data bases have increased more modestly.
Table 12. World export shares of technology-intensive products: ${ }^{1} 1975$ and 1985 [Percent]

\begin{tabular}{|c|c|c|c|c|}
\hline \multirow[b]{2}{*}{ Product group } & \multicolumn{2}{|c|}{ Japan } & \multicolumn{2}{|c|}{ United States } \\
\hline & 1975 & 1985 & 1975 & 1985 \\
\hline Total ........ & 11.6 & 19.4 & 24.5 & 24.2 \\
\hline Aircraft and parts & .3 & .4 & 61.9 & 50.9 \\
\hline 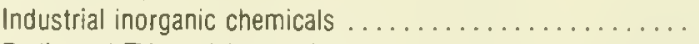 & 6.4 & 4.2 & 18.4 & 20.7 \\
\hline Radio and TV receiving equipment................ & 46.3 & 78.2 & 6.5 & .6 \\
\hline Office and computing machines..... & 9.2 & 17.7 & 31.3 & 33.1 \\
\hline Electrical machinery and equipment.. & 8.7 & 18.4 & 21.2 & 21.9 \\
\hline Communicatıons equipment ........... & 14.9 & 37.0 & 24.4 & 16.1 \\
\hline Professional and scientific instruments .............. & 15.3 & 30.0 & 19.6 & 16.9 \\
\hline Drugs. . . . . . . . . . . . . . & 2.0 & 2.7 & 13.6 & 18.4 \\
\hline Plastic materials, synthetics. & 12.0 & 9.6 & 12.0 & 13.2 \\
\hline Engines and turbines. & 8.7 & 17.7 & 25.9 & 29.4 \\
\hline Agricultural chemicals. . & 12.0 & 3.2 & 24.1 & 30.7 \\
\hline
\end{tabular}

'Technology-intensive products are defined as those for which US R\&O expenditures exceed 2.36 percent of sales (U S Oepartment of Commerce DOC 2 and Organisation for Economic $C_{0}$-operation and Development definition). Oata refiect intormation from 24 reporting countries on exports to. and imports trom. each of nearly 200 partner countries

SOURCE National Science Foundation, DRI Special Tabulations of International Trade, 1987 


\section{chapter 6.}

\section{possible future directions}

As Japan's leaders look to the next century, they have identified areas of change for Japanese S/T efforts. These areas are characterized by three major policy themes involving (1) a shift in research focus to more fundamental scientific research, (2) a reform of some of the more constraining aspects of the Japanese $\mathrm{S} / \mathrm{T}$ system, and (3) greater participation within the international scientific community.

\section{shifts in focus}

Perhaps the most important statement concerning the need for change is the Eleventh Recommendation by the Council for Science and Technology, which reflects a growing consensus sentiment in Japan that the nation must become more selfreliant in the production of science and technology. This recommendation acknowledges Japan's use of foreign technology, but cautions:

Japan will no longer have any model in the world to lead her future. Therefore, it is absolutely necessary for Japan to make efforts, trials, and even errors. That means Japan will have no way to ensure the development of the nation, without plentiful stocks of fundamental basic research activities. ${ }^{50}$

The recommendation goes on to stress the importance of "promoting creativeness in science and technology" by placing greater emphasis on fundamental research and strengthening interaction with scientists from other nations.

A second major concern of the Council's recommendation is to promote new fields of scientific and technological inquiry. Altogether, 103 S/T fields are given high priority: 33 in fundamental and leading science and technology, 33 concerning science and technology for economic development, and 37 concerning science and technology for improving the quality of society and life.

${ }^{50}$ Council for Science and Technology, Comprehensize Fundamental Policy for Promotion of Science and Techology to Focus Current Changing Situations from the Long-Term Virc: Recommendation on the 11 th Inquiry (Tokyo, Japan, November 1984).
The recommendation places greatest stress on the first group, butsince the areas covered by the report are so comprehensive and interdependent-it is difficult to judge which specific needs will actually receive the highest funding priority.

Other sources do provide additional indicators of short-term priorities, however. Concerning basic research, the best resource is the list of topics supported by the Ministry of Education, Science, and Culture (Monbusho) under the Specially Promoted Distinguished Research Program. (See appendix D.) These topics have received exceptionally careful competitive review and represent the highest quality and most advanced Japanese basic research. They are skewed towards biological medicine and biology, physics, and electrical engineering.

Another source for determining future Japanese $S / T$ directions is the list of research areas considered most important by the panelists of the 1986 Delphi Survey. The panelists, consisting of some 2,500 individuals in positions of research leadership from all research sectors, rated research areas in terms of their importance. 
Table 13 lists the areas ranked highest in the 1986 survey. On this, cancer represents four out of the top five areas of concern. Earlier surveys also showed strong emphases on life science and health; however, in the 1986 survey areas related to electronics and computer communications are newly identified. The research areas of major focus involve health, industrial technology, and energy.

Trends in the funding of scientific research and of research leaders' views on high priority areas are confirmed by a similar pattern in government focus: biotechnoloogy, information science, and energy-related research also represent the major ERATO and AIST research programs. Thus, for the next several years, these seem likely to be the major areas of enhanced research activity. At the same time, Japan probably will continue to emphasize other areas of current strength, such as chemistry and advanced materials.

\section{structural reforms}

Another areas of prospective change in Japanese $S / T$ concerns the organization of research funding and performance. The government's declining role in terms of $R \& D$ funding and expenditures is likely to continue in response to constrained

Table 13. Areas listed as most important in the 1986 Delphi Survey

\begin{tabular}{|c|c|}
\hline $\begin{array}{l}\text { Percent of leaders who } \\
\text { ranked area high }\end{array}$ & Area \\
\hline 96 & Preventive measures for cancer metastasis \\
\hline 95 & Elucidate the biological cause and development of cancer cells \\
\hline 91 & Development of technologies for major earthquake torecasting \\
\hline 90 & Measures for controlling the growth of cancer cells \\
\hline 89 & Clarify growth mechanism of cancer cells \\
\hline 88 & Storage and disposal of high-level radioactive solid wastes \\
\hline 88 & $\begin{array}{l}\text { Automatic protocol conversions to tacilitate information flows between } \\
\text { communication networks }\end{array}$ \\
\hline 87 & $\begin{array}{l}\text { Establishment of global integrated services digital network with automatic } \\
\text { domestic access }\end{array}$ \\
\hline 86 & $\begin{array}{l}\text { Application of CAD technology to design logic LSI semiconductors of } 1 \\
\text { million gates or more }\end{array}$ \\
\hline 86 & $\begin{array}{l}\text { Advanced software verification technology for rapid development of error- } \\
\text { free, large software systems }\end{array}$ \\
\hline 86 & $\begin{array}{l}\text { Introduction of tast breeder reactors and establishing complete nuclear fuel } \\
\text { cycle facilities }\end{array}$ \\
\hline 85 & Widespread use of anti-virus agents for treatment of viral diseases \\
\hline 84 & Industrial application of superconducting materials with Tc higher than $77 \mathrm{~K}$ \\
\hline 84 & $\begin{array}{l}\text { Methodologies for analysis of protein structures so as to predict their } \\
\text { functions }\end{array}$ \\
\hline 84 & $\begin{array}{l}\text { Technologies tor designing primary protein structures to fulfill specific } \\
\text { functions }\end{array}$ \\
\hline 84 & Molecular biology of brain development and growth \\
\hline 84 & New materials for use in "round-trip" space vehicles \\
\hline 84 & Prevention of senile dementia \\
\hline 84 & $\begin{array}{l}\text { New railway materials to significantly reduce environmental noise and } \\
\text { vibration }\end{array}$ \\
\hline 83 & Molecular biology of immunological responses \\
\hline 83 & $\begin{array}{l}\text { Establishment of commercial space production of semiconductors and } \\
\text { pharmaceuticals }\end{array}$ \\
\hline
\end{tabular}

NOTE. Adapted from translation provided by the Tokyo Otfice of the U $S$ National Science Foundation

SOURCE Government of Japan, Science and Technology Agency. Seplember 1987

public spending. ${ }^{51}$ In addition to limiting R\&D funds, the Japanese Government is currently promoting two major reforms that aim to improve the administration of public research funds and stimulate educational diversity.

Administrative reform. As a corollary of fiscal reform, a special external committee has been established to propose various measures of administrative reform, such as the elimination of redundant agencies and improved management methods. One of the principal targets of this committee has been the large number of research institutes supported by the various government ministries. While it is difficult to close down established institutes, a recent trend in establishing new ones has been to set their life span for a fixed period, often between 6 and 10 years. Another outcome has been strengthening the role of STA in science policy formation by increasing its support responsibilities to the Prime Minister's Council for Science and Technology..$^{52}$

Educational reform. Japanese reformers wish to restructure the educational system in order to foster a more creative and international citizenry. The major focus in this initiative is to alleviate the problems associated with extreme educational competition, among which is the excessive homogeneity in the upbringing of young people, all of whom strive to enter the same universities. By restructuring the educational system, it is hoped that more young

\footnotetext{
siln reaction to the heavy deficits incurred by the large-scale public construction programs of the seventies, the Japanese Government has been pursuing a strict deficit reduction policy for the past few years S/T funding has, however, increased very modestly (about 3 percent a year) and has tended to do better than many other government programs

${ }^{52}$ See the Tokyo Office of the U.S. National Science Foundation, Reorganization of Japan's Science and Technology Agency, Report Memorandum \#85, October 1985; and Reorganization of Science and Technology Agency (STA), Report Memorandum \#105. July 1986.
} 
people will feel free to develop specialized talents and a greater creativity. The reformers also urge for the breakdown of barriers between educational and other institutions. ${ }^{53}$

If carried out, these reforms will have a profound effect on future patterns in the funding and conduct of Japanese R\&D. The declining level of government support means that resources provided by other sectors-especially industry-would have to be more widely dispersed if Japan's research resources are to be fully utilized. If the educational reforms are successful, the Japanese can encourage more flexibility and creativity in their educational system and, in turn, foster greater research creativity for Japan's future S/T needs.

University-industry-government cooperation. While Japan's universities now have some of the best researchers and some of the most advanced equipment available, they are relatively short of research funds and, until recently, academic scientists have been restricted in their use of research funds from industry. As Japan promotes fundamental research, it will be necessary to draw on the universities for joint projects with industry. There already have been some important initiatives along these lines. A number of administrative reforms by Monbusho now makes industry-university cooperation easier; further, it is anticipated that a variety of new arrangements will emerge to promote universitygovernment research. ${ }^{54}$

\footnotetext{
${ }^{53}$ For a more detailed discussion of proposed educational reforms, see U.S. Department of Education, Japanese Education Today (Washington, D.C. Supt. of Documents, U.S. Government Printing Office, January 1987).

${ }^{54}$ See the Tokyo Office of the U.S. National Science Foundation, University-Industry Cooperation in Japan: New Policy Gizes Unizersities More Flexibility with Funds from Industry, Report Memorandum \#64, January 1985; and Current Progrants to Support Unnversity/lndustry Cooperation in Japan, Report Memorandum \#69, March 1985. Also see Masahiro Nishio, Collaboration Between University and Industry-lapanese Case, the Second Seminar on Japanese-GermanSwedish Cross-Country Studies on Structure and Function of Basic Technology Research, unpublished paper.
}

Additionally, during the late seventies one of the most impressive developments in Japan was the fostering of new arrangements in which government and business joined in research projects. MITI's effort to develop future technologies in semiconductors and fifth generation computers is the most noted example, and similar new government programs aimed at basic research are likely to plant the seeds for future industrial commercialization.

Most government-initiated reforms of the Japanese $\mathrm{S} / \mathrm{T}$ structure are designed to leverage the $R \& D$ funds of the three major R\&D performers. The decreasing contribution of government funds, combined with an identifiable need for moreand often more expensive-basic research has highlighted the necessity for greater collaborative research and access to resources among the government, industry, and higher education sectors. Many recent and imminent reforms have been aimed at removing the legal obstacles inhibiting the joint use of financial, human, and laboratory resources to enhance the research potential of $R \& D$ expenditures, regardless of source.

\section{internationalism}

The third dominant theme in Japanese S/T policy is a concern with increased participation in international scientific activities and increased openness to foreign participation in Japanese science. Most of Japan's recent policy statements acknowledge the country's access to and use of Western science and technology during the first century of Japan's modernization. Looking to the future, Japan's leaders wish to reciprocate. Moreover, they hope that increased generosity on Japan's part will enable Japanese researchers to maintain and enhance the quality of their profes- sional contact with Western colleagues.

Over the past few years, the level of Japanese funding for scientific and educational exchanges has increased rapidly, and several new programs have been initiated specifically for foreign scientists. Many of the government's new research programs, including ERATO and the Frontier Research Program, also make specific provision for the participation of foreign researchers. Most recently, the job classifications of civil servants have been revised; this now makes it possible for foreign scholars to hold research and teaching positions in Japanese universities and in government laboratories. Finally, many major Japanese corporations have expressed a willingness to receive American researchers in their laboratories. ${ }^{55}$

The Japanese are also trying to make their S/T literature more accessible to other nations. The Japan Information Center of Science and Technology is establishing an English-language data base of research reports issued by government agencies and research institutes; this data base will be integrated into the international Science and Technology Information Network. ${ }^{56}$ These efforts derive from both Japan's assessment of its needs and responsibilities as well as from a certain amount of pressure by other industrialized nations.

\footnotetext{
${ }^{55}$ See the Tokyo Office of the U.S. National Science Foundation, Directory of Japanese Comparty Laboratories Willing to Receize Amterican Resenchers, Report Memorandum \#92, January 1986.

${ }^{56} \mathrm{~A}$ comprehensive listing of English-language resources on Japanese science, technology, and enginering literature may be found in U.S. Department of Commerce, National Technical Information Service, Directory of Japanese Technical Resources 1987. The directory may be obtained from the National Technical Information Service, Office of International Af fairs, U.S. Department of Commerce, Springfield, Va. 22161; phone number (703) 487-4819.
} 


\section{trends in r\&d expenditures}

One of the key questions regarding Japan's future R\&D efforts is whether the nation is willing and able to sustain the growth rates that have characterized the $1965-85$ period. Of some concern to U.S. policymakers is Japan's willingness and ability to follow through on its objective to increase the level of basic research in Japan.

The Japanese have proposed to expand R\&D funding to 3.5 percent of national income, a ratio that had not quite been achieved as of $1985 .{ }^{57}$ However, given the trends in R\&D expenditures and the predominance of industry as the major source and performer of R\&D, it would be surprising if the level of $R \& D$ funding suddenly stabilized once the 3.5percent figure was realized. Because the rates of change in industry $R \& D$ have been so consistently high for so long, it would seem that real, annual, and large increases in $R \& D$ are an integral part of industrial activity in Japan.

However, real growth in industrial R\&D from 1985 to 1986 was only 1.3 percent, the lowest increase in the 1965-86 period except for 197475. (From 1965 to 1970 , industrial

\footnotetext{
7 Japanese policymakers use a different R\&D indicator for their decisionmaking purposes than the ones which have been used throughout this report. For them, the key ratio is R\&D in natural sciences and engineering to national income; this was 2.4 percent in 1980 and 3.2 percent in 1985
}

R\&D spending expanded at a real average annual rate of 20 percent; from 1970 to 1980,6 percent; and from 1980 to 1985,12 percent.) While this low increase may reflect a new phase in Japanese industrial R\&D effort, it more than likely is a response to the severe economic situation in Japan during 1986. Economic performance in that year was the second worst in the entire postwar period, surpassed only by the oil shock of 1974 . However, even in 1986-and except for the years 1971 and 1975-76-real increases in total Japanese R\&D expenditures matched or significantly outpaced the real rate of change in GNP.

Concurrent with greater industrial activity is the declining role by government both as a source of R\&D funds and as a performer of R\&D. Although Japanese Government R\&D funding increased at an annual average rate of 6 percent during the seventies, this rate declined to about 3 percent from 1980 to 1985 . Similarly, government performance of $R \& D$ is slowing down, from an annual average rate of 7 percent during $1970-80$ to 4 percent from 1980 to 1985.

The significance of industry in the Japanese $\mathrm{S} / \mathrm{T}$ system is reinforced given the recent trends in basic research expenditures: ${ }^{58}$ the Japanese Government has increased its basic research performance by barely 1 percent a year from 1980 to 1985 , compared with 3 percent from 1975-

\footnotetext{
${ }^{58}$ For a discussion of differences in U.S. and Japanese definitions of basic research, see appendix A
}

80. In contrast, industry increased its expenditures on basic research by an average annual rate of 16 percent during 1980-85, compared to 7 percent during 1975-80. The higher education sector, which now performs about one-half of Japan's basic research, increased its basic research expenditures by 10 percent annually from 1975-80, but from 1980 to 1985 this rate declined to about 4 percent per year.

Thus, for the $1980-85$ period it appears that Japanese industry is rising to the challenge of continued increases in Japan's total R\&D and basic research. Although the performance of $R \& D$ in Japan has historically been compartmentalized (e.g., the flow of funds among sectors and joint use of resources have been limited), as reforms are made throughout the R\&D system, the ability of the Japanese to improve the efficiency of their research funds may be increased. Collaborative research projects among sectors, the opportunity by industry to fund academic research, and the leveraging of research expenditures can enhance the relative productivity of $R \& D$ in Japan, especially that of basic and applied research.

While the low real increase in $R \& D$ expenditures from 1985 to 1986 is some cause for concern, it is most likely a reflection of the economic contraction and "yen shock" of 1985 and 1986. The macroeconomic structural adjustments that took place in Japan during 1986-87 have put the economy on a stronger footing, and any consequent revival of $R \& D$ spending should begin to show up in the $R \& D$ data for the years 198789. 


\section{appendixes}

a. technical notes

b. detailed statistical tables

c. japanese government research programs

d. awards under the specially promoted distinguished research program of the ministry of education 



\section{appendix a}

\section{technical notes}

Differences in definitions, concepts, and data collection and reporting practices make precise crosscountry comparisons difficult. However, much has been done by the Organisation for Economic Co-operation and Development (OECD) to establish uniform standards and definitions for scientific and technical activity. The Japanese and U.S. data presented here generally reflect OECD definitions and guidelines. ${ }^{1}$ Differences between the U.S. and Japanese data are discussed in more detail below, together with additional technical information.

\section{sources of science resources data}

Japanese science resources data are principally available from two annual publications, The Report on the Survey of Research and Development (issued by the Statistics Bureau of

${ }^{1}$ See Organisation for Economic Co-operation and Development, The Measurement of Scientific and Techmcal Actionties (Pans, France, 1981), commonly called the Frascati Manual. the Management and Coordination Agency) and Indicators of Science and Technology (issued by the Science and Technology Agency). Data in the Survey are obtained from annual questionnaires sent to the performers of research and development (R\&D) in Japan-industry, institutes of higher education, and government and nonprofit research institutes. The data in the Indicators are primarily a subset of the Survey data: the Indicators presents much of the same types of data but only for the natural sciences and engineering. However, the Indicators also presents additional information not available in the Survey, such as student enrollment and degree data, the technological balance of payments, and government budget data.

Science resources data for the United States are derived principally from reports and unpublished data of the U.S. National Science Foundation's Division of Science Resources Studies. A list of available data and publications may be obtained from the Office of the Division Director, Division of Science Resources Studies, National Science Foundation, 1800 G Street, N.W., Washington, D.C. 20550.
Additional data sources are as noted in the report text, tables, and charts, and include the OECD, various U.S. Government agencies, and scholarly works.

\section{expenditure data}

Expenditure data for both Japan and the United States are performerbased; that is, financial data on the source of R\&D funds and the amount of expenditures are obtained from surveys sent to the R\&D performers. In general, there are two major methods of calculating R\&D expenditures-on a current operating cost basis and on a disbursement basis. The United States uses the current operating cost method, which includes the costs of labor, materials, and the depreciation of tangible fixed assets. Capital expenditures are excluded by definition as a current operating cost.

An alternative method that Japan and many European countries use for calculating R\&D expenditures is on a disbursement basis, which also includes the costs of labor and materials, but substitutes capital expenditures (on facilities and 
equipment) for depreciation. AIthough data are available to make some estimates of Japanese R\&D on a current operating cost basis, these estimates would still not be precisely comparable to the various U.S. data series and in some instances offer no advantage over disbursement expenditure data. For consistency, all Japanese data are on a disbursement basis, with the understanding that disbursement expenditure data may be slightly higher than operating cost data. ${ }^{2}$

In terms of fields of coverage, both Japan and the United States include research in the natural sciences, engineering, and the social sciences. However, Japan, like many of the European countries, also includes in its $R \& D$ figures research activity in the humanities and education. The Japanese data in this report have not been adjusted to exclude the humanities and education, which constituted 6 percent of total Japanese R\&D expenditures in 1985, 27 percent of higher education expenditures (this is discussed in more detail in chapter 4, "Higher Education"), and 4 percent of government and nonprofit expenditures.

Japanese expenditure data for all $R \& D$ performers are reported for the fiscal year April 1 to March 31; U.S. data are reported primarily on a calendar year basis (industries and universities are allowed to report on their own fiscal year basis, which may or may not coincide with the calendar year). However, any differences between the Japanese and U.S. data series which result from noncoincident periods of time are certainly slight, and do not affect trends over time.

\footnotetext{
${ }^{2}$ An examination of Japanese industry data for the period 1980-85 showed that for all industries combined, R\&D expenditures based on operating costs were consistently about 7 percent less than dis bursement expenditures.
}

\section{personnel}

The international convention for reporting $R \& D$ personnel data is to include only that portion of a researcher's time actually devoted to research. One of the more problematic differences between the Japanese and U.S. data is that the U.S. numbers of scientists and engineers engaged in $R \& D$ are reported on a full-time-equivalent (FTE) basis; corresponding Japanese data report the gross total of scientists and engineers engaged in R\&D. While this is generally not a problem when comparing scientists and engineers in the industrial and government sectors (since they are presumably working full-time on R\&D), it does become a problem for the higher education sector where a researcher's time is divided among research, teaching, and administrative responsibilities.

To compensate somewhat for this difference, this report excludes Japanese scientists and engineers engaged in R\&D in the social sciences and humanities. This adjustment results in a 21-percent understatement of the total number of Japanese scientists and engineers engaged in $R \& D$ and a 40-percent understatement for the university sector. ${ }^{3}$

\footnotetext{
${ }^{3}$ This method for estimating the number of FTE scientists and engineers engaged in R\&D yields similar results to those obtained by a Japanese study. This study surveyed researchers affiliated with universities and derived an FTE coefficient of 0.6 for teaching staff. See Institute for Future Technology, Study on the Situation of Statistics Related to Research and Development Activity in the United States and Europe, and a Comparison whth the Stluation in Japan (Tokyo, Japan, March 1987)
}

\section{currency conversions}

This report expresses most monetary figures in terms of constant 1982 dollars while Japanese official documents publish R\&D funding and expenditure data in current yen. For this report, current yen have been converted into current U.S. dollars using OECD purchasing power parities (PPPs), and then converted into constant 1982 dollars using the U.S. Department of Commerce gross national product (GNP) implicit price deflators.

Market exchange rates have not been used for the currency conversion because they have become increasingly unsatisfactory in recent years for international statistical comparisons. Given the volatility of contemporary international capital markets, the international value of a currency is not a consistent reflection of the price structure for goods and services within a country, and consequently does not fully reflect the currency's purchasing power. Quite simply, PPPs for Japan are the number of yen needed to buy the same quantity of goods and services in Japan as a dollar can buy in the United States. ${ }^{4}$ In this manner, Japanese yen are converted into dollar terms representing the same purchasing power as a U.S. dollar in the United States.

While PPPs provide more comparable data by equalizing how much a respective currency can buy, they are based on a broad index (or basket) of consumer goods and services

\footnotetext{
"The OECD has calculated PPPs for its member countries; all PPPs are expressed in terms of units of foreign currency per U.S. dollar
} 
and thus do not exactly reflect price structures specific to the costs of R\&D in a country. This is somewhat of a limitation in terms of making precise international comparisons with regard to R\&D; nevertheless, the use of PPPs to convert R\&D expenditure data and national income data still yields a more accurate picture of relative spending levels than the use of market exchange rates. For a detailed discussion of the methodology for computing PPPs, see OECD, Purchasing Power Parities and Real Expenditures in the OECD (Paris: 1985).

\section{basic research}

Although basic research is defined in virtually identical terms in both the United States and Japan (i.e., research that is conducted for the purpose of advancing scientific knowledge and without specific applications being directly sought), the interpretation of this definition seems to differ in Japan and the United States. Understandably, the allocation of research as basic or applied is a subjective process, and even in the United States there is disagreement over the distinction between these two types of research. ${ }^{5}$

The conceptual differences between Japanese and American perceptions arise in allocating research

\footnotetext{
${ }^{5}$ See Arthur Gerstenfeld, Science Policy Perspectizes: USA-lapan, (New York, New York: Academic Press, Inc., 1982), especially "Part 1: Perceptions of the Nature of Basic and Applied Science."
}

that is not "truly" basic research (e.g." particle physics). In the United States, the relationship between basic and applied research is typically seen as both mutually exclusive and linear: applied research cannot be basic, and applied research occurs after basic research in a unidirectional flow of research activity. Once a goal or objective other than the pure pursuit of scientific knowledge is assigned to a research program, then it is traditionally seen as applied-not basic_research.

In Japan, however, basic and applied research are perceived in a more multidimensional and interactive way than in the United States. One of the key differences between the two countries seems to be that in considering whether research is applied or basic, the type of science (basic or applied) being used is also considered. Thus, a long-term applied research program (one with a problem or application in mind) that extensively uses basic science experimentation for its problem resolution might be classified as basic research in Japan. ${ }^{6}$ Consequently, Japanese data on basic research expenditures probably include some types of research that would be classified as applied research in the United States. Note that the Japanese exclude R\&D in the social sciences and humanities in the allocation of research by character of work.

\footnotetext{
'See Gerstenfeld, op. cit., and Institute for Future Technology, op. cit.
}

\section{manufacturing industries}

At the aggregate level, the Standard Industrial Classifications for manufacturing industries in Japan and the United States are very similar, with a key exception being the placement of computers in the classification scheme. In the United States, computers are classified as "office, computing, and accounting machines" under general machinery; in Japan, they are classified under electrical machinery as "communications and electronic equipment." To make the R\&D data in this report as comparable as possible, the U.S. general machinery subgroup "office, computing, and accounting machines" data has been moved to "communications and electronic components" under electrical machinery.

This adjustment was made because (1) the U.S. data were readily available, and (2) only one straightforward statistical adjustment was required to make the two categories (general and electrical machinery and their subgroups) completely comparable. To adjust the Japanese data would have required several statistical changes for which there were insufficient data.

As a last note, the Japanese Standard Industrial Classification does not contain a separate "3-digit level" category for aircraft and missiles. Aircraft are included under "other transportation equipment"; missiles are not identified in the classification schedule. 



\section{detailed statistical tables}

B-1. National expenditures for the performance of R\&D: 1965-86 ......

B-2. National expenditures for the performance of $R \& D$ as a percent of GNP: 1965-86 .....

B-3. Estimated nondefense $R \& D$ expenditures as a percent of GNP: 1971-85

B-4. National R\&D

funding by source:

selected years .........

B-5. Distribution of national $R \& D$ expenditures by performer: selected years
Page

B-6. National R\&D expenditures by performer and character of work: selected years .........

B-7. Scientists and engineers engaged in R\&D: 1965-86

B-8. Number of scientists and engineers engaged in $R \& D$ by sector: 1985

B-9. Value of technical know-how receipts and expenditures: 1970 and 1985 ........

B-10. Value of government R\&D funding: 1970-

Page
B-11. Distribution of Japanese Government R\&D budget among key Japanese ministries and agencies: 1985

B-12. Distribution of government $R \& D$ expenditures by objective: 1985

B-13. Distribution of Japanese Governmen $R \& D$ funding by objective: selected years .......................

B-14. National industrial

R\&D expenditures:

1965-86

B-15. National industrial R\&D as a percent of GNP: 1965-86 
B-16. Japanese

manufacturing R\&D

expenditures by

industry: selected

years

B-17. Manufacturing R\&D activity by industry: 1985

B-18. Shares of manufacturing $R \& D$ accounted for by the five largest $R \& D$ firms by industry: 1985

B-19. Number of industrial scientists and engineers engaged in R\&D: 1965-85

B-20. Higher education $R \& D$ expenditures: 1965-86
B-21. Distribution of higher education R\&D expenditures among fields: 1985

B-22. Distribution of academic separately budgeted $R \& D$ by field: 1982

B-23. First-university degrees by field and as a proportion of the 22-year-old population: 1985

B-24. Doctoral degrees by field and as a proportion of the 27 year-old population: 1984 or 1985

B-25. Trends in scientific literature outputs:
B-26. Japanese-invented U.S. patents by selected patent classes: 1975-84

B-27. Output per workerhour in manufacturing:

1965-85

B-28. Japanese manufacturing use of technical know-how by selected industries: 1975 and 1985

B-29. Japanese trade balance with the United States in technology-intensive products: 1965-85 ...

B-30. World export shares of technologyintensive products: 
Table B-1. National expenditures for the performance of R\&D: $1965-86$

[Constant 1982 dollars in millions] ${ }^{1}$

\begin{tabular}{|c|c|c|c|}
\hline & Year & Japan & $\begin{array}{l}\text { United } \\
\text { States }\end{array}$ \\
\hline 1965 & $\ldots \ldots \ldots$ & $\$ 6,133$ & $\$ 59,351$ \\
\hline 1966 & $\ldots \ldots \ldots$ & 6,621 & 62.589 \\
\hline 1967 & $\ldots \ldots \ldots$ & 7,626 & 64,406 \\
\hline 1968 & $\ldots \ldots \ldots$ & 9,060 & 65,458 \\
\hline 1969 & $\ldots \ldots \ldots \ldots$ & 10,487 & 64,672 \\
\hline 1970 & $\ldots \ldots \ldots$ & 12,442 & 62,405 \\
\hline 1971 & $\ldots \ldots \ldots$ & 13,321 & 60,385 \\
\hline 1972 & $\ldots \ldots \ldots$ & 14,751 & 61.414 \\
\hline 1973 & $\ldots \ldots \ldots$ & 16,159 & 62,427 \\
\hline 1974 & $\ldots \ldots \ldots$ & 16,395 & 61,467 \\
\hline 1975 & $\ldots \ldots \ldots$ & 16,673 & 59,883 \\
\hline 1976 & $\ldots \ldots \ldots$ & 17,371 & 62,134 \\
\hline 1977 & $\ldots \ldots \ldots$ & 18,042 & 63,653 \\
\hline 1978 & $\ldots \ldots \ldots$ & 19,087 & 66,769 \\
\hline 1979 & $\ldots \ldots \ldots$ & 20,985 & 70,077 \\
\hline 1980 & $\ldots \ldots \ldots$ & 23,139 & 73,235 \\
\hline 1981 & $\ldots \ldots \ldots$ & 25,570 & 76,610 \\
\hline 1982 & $\ldots \ldots \ldots$ & 27,397 & 79,316 \\
\hline 1983 & $\ldots \ldots \ldots$ & 29,904 & 83,891 \\
\hline 1984 & $\ldots \ldots \ldots$ & 32,480 & 90,541 \\
\hline 1985 & $\ldots \ldots \ldots$ & 36,023 & 96.532 \\
\hline 1986 & $\ldots \ldots \ldots$ & 36,605 & 100,398 \\
\hline
\end{tabular}

${ }^{1}$ Based on Organisation for Economic Co-operatıon and Development purchasing power parities and U.S Department of Commerce GNP Implicit price deflators.

SOURCES Government of Japan, Management and Coordination Agency, and the National Science Foundation
Table B-2. National expenditures for the performance of R\&D as a percent of GNP: 1965-86

[Constant 1982 dollars in billions]

\begin{tabular}{|c|c|c|c|c|}
\hline \multirow[b]{2}{*}{ Year } & \multicolumn{2}{|c|}{ GNP } & \multicolumn{2}{|c|}{ R\&D as a percent of GNP } \\
\hline & Japan & United States & Japan & United States \\
\hline $1965 \ldots \ldots \ldots \ldots \ldots \ldots$ & $\$ 405$ & $\$ 2,087$ & 1.5 & 2.8 \\
\hline $1966 \ldots \ldots \ldots \ldots \ldots$ & 453 & 2,208 & 1.5 & 2.8 \\
\hline $1967 \ldots \ldots \ldots \ldots \ldots \ldots$ & 501 & 2,272 & 1.5 & 2.8 \\
\hline $1968 \ldots \ldots \ldots \ldots \ldots \ldots$ & 565 & 2.366 & 1.6 & 2.8 \\
\hline $1969 \ldots \ldots \ldots \ldots \ldots \ldots$ & 639 & 2.423 & 1.6 & 2.7 \\
\hline $1970 \ldots \ldots \ldots \ldots \ldots \ldots$ & 671 & 2,416 & 1.9 & 2.6 \\
\hline $1971 \ldots \ldots \ldots \ldots \ldots \ldots$ & 719 & 2,485 & 1.9 & 2.4 \\
\hline $1972 \ldots \ldots \ldots \ldots \ldots \ldots$ & 794 & 2,609 & 1.9 & 2.3 \\
\hline $1973 \ldots \ldots \ldots \ldots \ldots \ldots$ & 851 & 2,744 & 1.9 & 2.3 \\
\hline $1974 \ldots \ldots \ldots \ldots \ldots$ & 833 & 2,729 & 2.0 & 2.2 \\
\hline $1975 \ldots \ldots \ldots \ldots \ldots$ & 851 & 2,695 & 2.0 & 2.2 \\
\hline $1976 \ldots \ldots \ldots \ldots \ldots$ & 891 & 2,827 & 2.0 & 2.2 \\
\hline $1977 \ldots \ldots \ldots \ldots$ & 933 & 2,959 & 1.9 & 2.2 \\
\hline 1978 & 956 & 3,115 & 2.0 & 2.1 \\
\hline $1979 \ldots \ldots \ldots$ & 1,002 & 3,192 & 2.1 & 2.2 \\
\hline $1980 \ldots \ldots \ldots$ & 1,040 & 3,187 & 2.2 & 2.3 \\
\hline $1981 \ldots \ldots \ldots \ldots \ldots \ldots$ & 1,074 & 3,249 & 2.4 & 2.4 \\
\hline $1982 \ldots \ldots \ldots \ldots \ldots \ldots$ & 1,108 & 3,166 & 2.5 & 2.5 \\
\hline $1983 \ldots \ldots \ldots \ldots \ldots \ldots$ & 1,144 & 3,279 & 2.6 & 2.6 \\
\hline $1984 \ldots \ldots \ldots \ldots \ldots \ldots$ & 1,247 & 3,502 & 2.6 & 2.6 \\
\hline $1985 \ldots \ldots \ldots$ & 1,300 & 3,607 & 2.8 & 2.7 \\
\hline $1986 \ldots \ldots \ldots \ldots \ldots$ & 1,317 & 3,713 & 2.8 & 2.7 \\
\hline
\end{tabular}

NOTE Percentages calculated from national currencies.

SOURCES: Organisation for Economic Co-operation and Development, Government of Japan. Management and Coordination Agency: and the National Science Foundation
Table B-3. Estimated nondefense R\&D expenditures as a percent of GNP: $1971.85^{1}$

\begin{tabular}{|c|c|c|c|}
\hline & Year & Japan & $\begin{array}{l}\text { United } \\
\text { States }\end{array}$ \\
\hline 1971 & $\ldots \ldots \ldots$ & 1.8 & 1.6 \\
\hline 1972 & ... & 1.8 & 1.6 \\
\hline 1973 & . & 1.9 & 1.6 \\
\hline 1974 & $\ldots$ & 2.0 & 1.6 \\
\hline 1975. & $\ldots \ldots \ldots \ldots$ & 1.9 & 1.6 \\
\hline 1976 & $\ldots \ldots \ldots$ & 1.9 & 1.6 \\
\hline 1977 . & $\ldots \ldots \ldots$ & 1.9 & 1.6 \\
\hline 1978 & & 2.0 & 1.6 \\
\hline 1979 & $\ldots \ldots \ldots$ & 2.1 & 1.7 \\
\hline 1980 & $\ldots \ldots \ldots$ & 2.2 & 1.8 \\
\hline 1981 & $\ldots \ldots \ldots$ & 2.4 & 1.8 \\
\hline 1982 & $\ldots$ & 2.5 & 1.9 \\
\hline 1983 & & 2.6 & 1.9 \\
\hline 1984 & & 2.6 & 1.8 \\
\hline 1985 & $\ldots \ldots \ldots$ & 2.8 & 1.9 \\
\hline
\end{tabular}

${ }^{1}$ Data on nondefense R\&D expenditures are not avallable prior to 1971

NOTE Percentages calculated from unrounded figures

SOURCES: Organisation for Economic Co-Operation and Development and the National Science Foundation 
Table B-4. National R\&D funding by source: selected years

[Constant 1982 dollars in millions]

\begin{tabular}{|c|c|c|c|c|}
\hline Year & Government & Industry & $\begin{array}{l}\text { Higher } \\
\text { education }\end{array}$ & Other ${ }^{1}$ \\
\hline \multirow{3}{*}{ 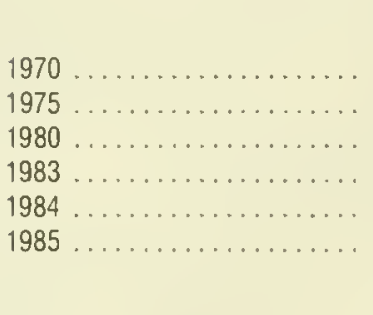 } & \multicolumn{4}{|c|}{ Japan } \\
\hline & $\begin{array}{r}3,663 \\
4,899 \\
6,462 \\
7,169 \\
7,315 \\
7,566\end{array}$ & $\begin{array}{r}6,838 \\
9,177 \\
14,090 \\
19,484 \\
21,719 \\
24,809\end{array}$ & $\begin{array}{r}\$ 1,861 \\
2,498 \\
2,425 \\
3,024 \\
3,188 \\
3,333\end{array}$ & $\begin{array}{r}80 \\
88 \\
161 \\
227 \\
258 \\
315\end{array}$ \\
\hline & \multicolumn{4}{|c|}{ Percent } \\
\hline 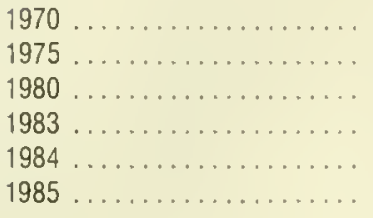 & $\begin{array}{l}29 \\
29 \\
28 \\
24 \\
23 \\
21\end{array}$ & $\begin{array}{l}55 \\
55 \\
61 \\
65 \\
67 \\
69\end{array}$ & $\begin{array}{r}15 \\
15 \\
11 \\
10 \\
10 \\
9\end{array}$ & $\begin{array}{l}1 \\
1 \\
1 \\
1 \\
1 \\
1 \\
1\end{array}$ \\
\hline $1985 \ldots \ldots \ldots \ldots \ldots \ldots$ & \multicolumn{4}{|c|}{ United States } \\
\hline 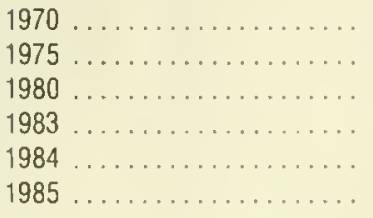 & $\begin{array}{l}\$ 35,636 \\
30,986 \\
34,548 \\
39,097 \\
42,007 \\
46,030\end{array}$ & $\begin{array}{l}\$ 24,851 \\
26,679 \\
36,066 \\
41,896 \\
45,544 \\
47,310\end{array}$ & $\begin{array}{l}\$ 1,111 \\
1,302 \\
1,555 \\
1,805 \\
1,871 \\
2,023\end{array}$ & $\begin{array}{r}\$ 807 \\
916 \\
1,066 \\
1,093 \\
1,119 \\
1,170\end{array}$ \\
\hline $1985 \ldots \ldots \ldots \ldots \ldots$ & \multicolumn{4}{|c|}{ Percent } \\
\hline 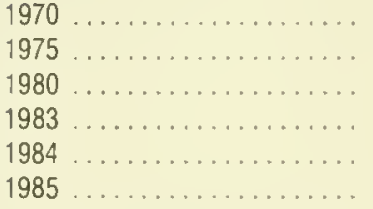 & $\begin{array}{l}57 \\
51 \\
47 \\
47 \\
46 \\
48\end{array}$ & $\begin{array}{l}40 \\
45 \\
49 \\
50 \\
50 \\
49\end{array}$ & $\begin{array}{l}2 \\
2 \\
2 \\
1 \\
2 \\
2\end{array}$ & $\begin{array}{l}1 \\
2 \\
2 \\
2 \\
1 \\
1\end{array}$ \\
\hline
\end{tabular}

NNomprolit institutions and lunds from abroad

NOTE Because of rounding percentages may not add to 100 . Percentages calculated from national currrencies

SOURCE SOurce of funds statistics are estimates based upon data from the Management and Coordination Agency and in collaboration with officials of the Science and Technology Agency 
Table B-5. Distribution of national R\&D expenditures by performer:

selected years

[Percent]

\begin{tabular}{|c|c|c|c|c|}
\hline Year & Government & Industry & $\begin{array}{l}\text { Higher } \\
\text { education }\end{array}$ & Other' \\
\hline & \multicolumn{4}{|c|}{ Japan } \\
\hline 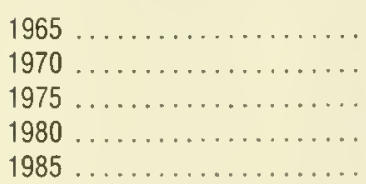 & $\begin{array}{r}12 \\
11 \\
12 \\
12 \\
9\end{array}$ & $\begin{array}{l}50 \\
61 \\
57 \\
60 \\
67\end{array}$ & $\begin{array}{l}36 \\
27 \\
28 \\
26 \\
20\end{array}$ & $\begin{array}{l}2^{2} \\
1 \\
3 \\
3 \\
4\end{array}$ \\
\hline $1985 \ldots \ldots \ldots \ldots \ldots \ldots$ & \multicolumn{4}{|c|}{ United States } \\
\hline 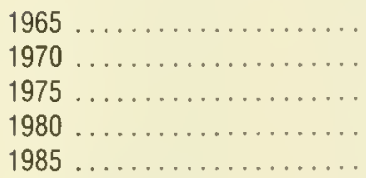 & $\begin{array}{l}15 \\
16 \\
15 \\
12 \\
12\end{array}$ & $\begin{array}{l}71 \\
69 \\
69 \\
71 \\
73\end{array}$ & $\begin{array}{l}11 \\
12 \\
13 \\
13 \\
12\end{array}$ & $\begin{array}{l}3 \\
4 \\
4 \\
3 \\
3\end{array}$ \\
\hline
\end{tabular}

'Nonprotit institutions

${ }^{2}$ Estimate made by the National Science Foundation

NOTE Because of rounding, percentages may not add to 100

SOURCES: Government of Japan. Management and Coordination Agency, and the National Science Founcation

Table B-6. National R\&D expenditures by performer and character of work: selected years ${ }^{\top}$

[Constant 1982 dollars in millions]

\begin{tabular}{|c|c|c|c|c|c|c|c|c|c|c|c|c|}
\hline \multirow[b]{2}{*}{ Performer } & \multicolumn{4}{|c|}{1975} & \multicolumn{4}{|c|}{1980} & \multicolumn{4}{|c|}{1985} \\
\hline & Total & $\begin{array}{c}\text { Basic } \\
\text { research }\end{array}$ & $\begin{array}{l}\text { Applied } \\
\text { research }\end{array}$ & $\begin{array}{c}\text { Develop- } \\
\text { ment }\end{array}$ & Total & $\begin{array}{c}\text { Basic } \\
\text { research }\end{array}$ & $\begin{array}{l}\text { Applied } \\
\text { research }\end{array}$ & $\begin{array}{c}\text { Develop- } \\
\text { ment }\end{array}$ & Total & $\begin{array}{c}\text { Basic } \\
\text { research }\end{array}$ & $\begin{array}{l}\text { Applied } \\
\text { research }\end{array}$ & $\begin{array}{c}\text { Develop- } \\
\text { ment }\end{array}$ \\
\hline \multirow{7}{*}{ 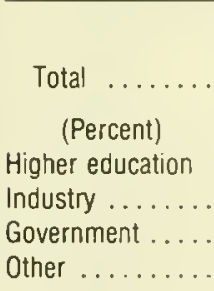 } & \multicolumn{12}{|c|}{ Japan } \\
\hline & $\$ 13,332$ & $\$ 2,013$ & $\$ 2,848$ & $S 8,470$ & $\$ 20,284$ & $\$ 3,121$ & S 5,138 & $\$ 12,025$ & $\$ 32,775$ & S 4,379 & S 8,164 & $\$ 20,232$ \\
\hline & $(100 \%)$ & $(15 \%)$ & $(21 \%)$ & $(64 \%)$ & $(100 \%)$ & $(15 \%)$ & $(25 \%)$ & $(59 \%)$ & $(100 \%)$ & $(13 \%)$ & $(25 \%)$ & $(62 \%)$ \\
\hline & 1,670 & 1,209 & 339 & 122 & 3,383 & 1,957 & 1,194 & 231 & 4,332 & 2,415 & 1,570 & 347 \\
\hline & 9,444 & 489 & 1,800 & 7,155 & 13,859 & 694 & 2,704 & 10,460 & 24,068 & 1,425 & 5,280 & 17,363 \\
\hline & 1,837 & 291 & 630 & 917 & 1,410 & 337 & 695 & 378 & 1,592 & 352 & 795 & 445 \\
\hline & 381 & 25 & 80 & 275 & 1,632 & 133 & 544 & 956 & 2,783 & 187 & 518 & 2,077 \\
\hline & \multicolumn{12}{|c|}{ United States } \\
\hline Total & 59,883 & 7,951 & 13,407 & 38,525 & 73,235 & 9,506 & 16,456 & 47.273 & 96,532 & 11,727 & 22,129 & 62,676 \\
\hline (Percent) & $(100 \%)$ & $(13 \%)$ & $(22 \%)$ & $(65 \%)$ & $(100 \%)$ & $(13 \%)$ & $(22 \%)$ & $(65 \%)$ & $(100 \%)$ & $(12 \%)$ & $(22 \%)$ & $(66 \%)$ \\
\hline Higher education & 7,642 & 4,727 & 1,938 & 977 & 9.803 & 5,679 & 2,822 & 1.302 & 11,669 & 6.675 & 3.257 & 1.737 \\
\hline Industry ........ & 40,781 & 1,231 & 7,705 & 31,845 & 51,920 & 1,546 & 9.858 & 40,516 & 70.350 & 2,364 & 15,212 & 52,774 \\
\hline Government.... & 9,308 & 1,276 & 3,008 & 5,024 & 9,006 & 1,395 & 2.931 & 4,680 & 11,590 & 1,722 & 2,805 & 7,063 \\
\hline Other ....... & 2,151 & 717 & 755 & 679 & 2,509 & 887 & 846 & 776 & 2,924 & 967 & 855 & 1,102 \\
\hline
\end{tabular}

'Not all Japanese R\&D expenditures are allocated by character of work, theretore, the 10tal R\&O expenditures presented above are not the same as those in table B-1 NOTE Because of rounding, figures may not add to totals shown Percentages calculated from national currencies

SOURCES Govemment of Japan. Management and Coordination Agency, and the National Science Foundation 
Table 8-7. Scientists and engineers engaged in R\&D: $1965-86^{1}$

\begin{tabular}{|c|c|c|c|c|}
\hline \multirow[b]{2}{*}{ Year } & \multicolumn{2}{|c|}{$\begin{array}{l}\text { Scientists and engineers } \\
\text { (in thousands) }\end{array}$} & \multicolumn{2}{|c|}{$\begin{array}{l}\text { Scientists and engineers engaged } \\
\text { in R\&D per } 10,000 \text { labor force }\end{array}$} \\
\hline & Japan & United States & Japan & United States \\
\hline $1965 \ldots \ldots \ldots \ldots \ldots$ & 117.6 & 494.6 & 24.6 & 64.7 \\
\hline $1966 \ldots \ldots \ldots \ldots \ldots$ & 128.9 & 521.1 & 26.4 & 66.9 \\
\hline $1967 \ldots \ldots \ldots \ldots \ldots$ & 138.7 & 534.4 & 27.8 & 67.2 \\
\hline $1968 \ldots \ldots \ldots \ldots \ldots \ldots$ & 157.6 & 550.4 & 31.1 & 68.0 \\
\hline $1969 \ldots \ldots \ldots \ldots \ldots$ & 157.1 & 553.2 & 30.8 & 66.7 \\
\hline $1970 \ldots \ldots \ldots \ldots$ & 172.0 & 544.2 & 33.4 & 64.1 \\
\hline $1971 \ldots \ldots \ldots \ldots \ldots$ & 194.3 & 523.8 & 37.5 & 60.7 \\
\hline $1972 \ldots \ldots \ldots \ldots \ldots$ & 198.1 & 515.3 & 38.1 & 58.0 \\
\hline $1973 \ldots \ldots \ldots \ldots \ldots$ & 226.6 & 514.8 & 42.5 & 56.4 \\
\hline $1974 \ldots$ & 238.2 & 520.8 & 44.9 & 55.6 \\
\hline $1975 \ldots$ & 255.2 & 527.7 & 47.9 & 55.3 \\
\hline $1976 \ldots \ldots \ldots \ldots$ & 260.3 & 535.6 & 48.4 & 54.8 \\
\hline $1977 \ldots \ldots \ldots$ & 272.0 & 561.0 & 49.9 & 55.7 \\
\hline $1978 \ldots$ & 273.1 & 587.0 & 49.4 & 56.5 \\
\hline $1979 \ldots$ & 281.9 & 614.8 & 50.4 & 57.7 \\
\hline $1980 \ldots \ldots \ldots \ldots \ldots$ & 302.6 & 651.7 & 53.6 & 60.0 \\
\hline $1981 \ldots \ldots \ldots \ldots \ldots$ & 317.5 & 683.7 & 55.6 & 62.0 \\
\hline $1982 \ldots \ldots \ldots \ldots \ldots \ldots$ & 329.7 & 702.8 & 57.1 & 62.8 \\
\hline $1983 \ldots \ldots \ldots \ldots \ldots$ & 342.2 & 722.9 & 58.1 & 63.8 \\
\hline $1984 \ldots \ldots \ldots \ldots \ldots$ & 370.0 & 746.3 & 62.4 & 64.8 \\
\hline $1985 \ldots \ldots \ldots \ldots \ldots$ & 381.3 & 772.5 & 63.9 & 65.9 \\
\hline $1986 \ldots \ldots \ldots \ldots$ & 405.6 & 802.3 & 69.3 & 67.1 \\
\hline
\end{tabular}

${ }^{1}$ U S figures are full-tıme equivalents, while Japanese represent total numbers of scientists and engineers engaged primarly in $\mathrm{A} \& 0$ in natural science and engineering

SOURCES Government of Japan. Science and Technology Agency, and the National Science Foundation

Table B-8. Number of scientists and engineers engaged in R\&D by sector: $1985^{1}$

[In thousands]

\begin{tabular}{c|c|c}
\hline \multicolumn{1}{c|}{ Sector } & Japan & $\begin{array}{c}\text { United } \\
\text { States }^{2}\end{array}$ \\
\hline Total ....... & 381.3 & 772.5 \\
\cline { 2 - 3 } $\begin{array}{c}\text { Industry ........ } \\
\text { Higher education } \\
\text { Government and } \\
\text { non-profit .... }\end{array}$ & 118.0 & 570.3 \\
\hline
\end{tabular}

'U S figures are full-tıme equivalents, while Japanese represent total numbers of scientists and engineers engaged primarly in $98 \mathrm{D}$ in natural sciences and engineering

${ }^{2} \mathrm{U} S$ figures for 1985 are estumates

SOURCES Government of Japan. Science and Technology Agency. and the National Science Foundation
Table B-9. Value of technical know-how receipts and expenditures: 1970 and 1985

[Constant 1982 dollars in millions]

\begin{tabular}{|c|c|c|c|c|}
\hline \multirow[t]{2}{*}{ Receipts and expenditures } & \multicolumn{2}{|c|}{1970} & \multicolumn{2}{|c|}{1985} \\
\hline & Japan & United States & Japan & United States \\
\hline $\begin{array}{l}\text { Receipts } \ldots \ldots \ldots \ldots \ldots \ldots \\
\text { Payments } \ldots \ldots \ldots \ldots \ldots \ldots \ldots \\
\text { Balance } \ldots \ldots \ldots \ldots \ldots \ldots \ldots \\
\text { Ratio of receipts to payments }{ }^{1} \ldots \ldots\end{array}$ & $\begin{array}{c}\$ 194 \\
1,423 \\
(1,229) \\
.136\end{array}$ & $\begin{array}{r}\$ 8,625 \\
2,503 \\
6,122 \\
3.45\end{array}$ & $\begin{array}{r}\$ 721 \\
2,437 \\
(1716) \\
.296\end{array}$ & $\begin{array}{r}\$ 14,018 \\
4,953 \\
9,065 \\
2.83\end{array}$ \\
\hline
\end{tabular}

${ }^{1}$ Ratios calculated from unrounded national currencies

SOURCES Government of Japan. Science and Technology Agency, and the National Science Foundation. Japanese data are statistics of the Bank of Japan 
Table B-10. Value of government R\&D funding: 1970-85

[Constant 1982 dollars in millions]

\begin{tabular}{|c|c|c|c|c|}
\hline \multirow[b]{2}{*}{ Year } & \multicolumn{2}{|c|}{ Japan } & \multicolumn{2}{|c|}{ United States } \\
\hline & $\begin{array}{l}\text { Government } \\
\text { R\&D funding }\end{array}$ & $\begin{array}{c}\text { As a share of } \\
\text { total } R \& D\end{array}$ & $\begin{array}{c}\text { Government } \\
\text { R\&D }\end{array}$ & $\begin{array}{c}\text { As a share of } \\
\text { total R\&D }\end{array}$ \\
\hline 1970 & $\$ 3,663$ & $29.4 \%$ & $\$ 35,636$ & $57.0 \%$ \\
\hline 1971 & 4,307 & 32.3 & 33,966 & 56.1 \\
\hline $1972 \ldots$ & 4,873 & 33.0 & 34,146 & 55.5 \\
\hline $1973 \ldots \ldots$ & 5,020 & 31.1 & 33,478 & 53.4 \\
\hline 1974 & 4,732 & 28.9 & 31,726 & 51.3 \\
\hline 1975 & 4,934 & 29.6 & 30,986 & 51.4 \\
\hline $1976 \ldots$ & 5,108 & 29.4 & 31,813 & 51.0 \\
\hline $1977 \ldots \ldots$ & 5,331 & 29.5 & 32,152 & 50.5 \\
\hline $1978 \ldots \ldots$ & 5,752 & 30.1 & 33,172 & 49.6 \\
\hline $1979 \ldots$. & 6,196 & 29.5 & 34,271 & 48.8 \\
\hline $1980 \ldots$ & 6,506 & 28.1 & 34,548 & 47.1 \\
\hline 1981. & 6,892 & 27.0 & 35,685 & 46.5 \\
\hline $1982 \ldots$ & 6,992 & 25.5 & 36,505 & 46.0 \\
\hline $1983 \ldots$ & 7,169 & 24.0 & 39,097 & 46.6 \\
\hline $1984 \ldots \ldots$ & 7,315 & 22.5 & 42,007 & 46.4 \\
\hline $1985 \ldots \ldots$ & 7,566 & 21.0 & 46,030 & 47.7 \\
\hline
\end{tabular}

NOTE: Percentages based on national currencies

SOURCES: Government of Japan, Management and Coordination Agency, and the National Science Foundation
Table B-11. Distribution of Japanese Government R\&D budget among key Japanese ministries and agencies: 1985

[Percent]

\begin{tabular}{|c|c|}
\hline Ministry/agency & $\begin{array}{l}\text { Share of total } \\
\text { R\&D budget }\end{array}$ \\
\hline Total & 100 \\
\hline $\begin{array}{c}\text { Ministry of Education, Science, } \\
\text { and Culture } \ldots \ldots \ldots \ldots \ldots\end{array}$ & 47 \\
\hline $\begin{array}{l}\text { Science and Technology } \\
\text { Agency } \ldots \ldots \ldots \ldots\end{array}$ & 27 \\
\hline $\begin{array}{l}\text { Ministry of International Trade } \\
\text { and Industry } \ldots \ldots \ldots \ldots \ldots\end{array}$ & 13 \\
\hline $\begin{array}{l}\text { Ministry of Agriculture, } \\
\text { Forestry, and Fisheries .... }\end{array}$ & 4 \\
\hline Defense Agency ........... & 4 \\
\hline Ministry of Health and Welfare & 2 \\
\hline 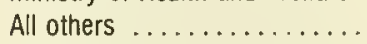 & 3 \\
\hline
\end{tabular}

SOURCE. Government of Japan, Science and Technology Agency
Table B-12. Distribution of government R\&D expenditures by objective: 1985

[Percent]

\begin{tabular}{|c|c|c|}
\hline Objective & $\operatorname{Japan}^{1}$ & $\begin{array}{l}\text { United } \\
\text { States }\end{array}$ \\
\hline Total & 100.0 & 100.0 \\
\hline $\begin{array}{l}\text { Agriculture, } \\
\text { forestry, and } \\
\text { fisheries ...... }\end{array}$ & 11.3 & 2.1 \\
\hline $\begin{array}{l}\text { Industrial } \\
\text { development } \ldots\end{array}$ & 5.9 & .2 \\
\hline Energy ........ & 16.3 & 4.8 \\
\hline Health $\ldots \ldots \ldots$ & 2.6 & 11.2 \\
\hline $\begin{array}{l}\text { Advancement of } \\
\text { knowledge }^{2} \ldots\end{array}$ & 47.3 & 3.7 \\
\hline Civil space ...... & 6.8 & 5.5 \\
\hline Defense & 4.1 & 67.5 \\
\hline All others ... & 5.7 & 5.0 \\
\hline
\end{tabular}

'NSF-adjusted tigures.

${ }^{2}$ The category "advancement of knowledge" includes general university funds spent on R\&D and should not be equated with basic research

SOURCES Japanese national sources and the National Science Foundation
Table B-13. Distribution of Japanese Government R\&D funding by objective: selected years

[Percent]

\begin{tabular}{|c|c|c|c|}
\hline Objective & 1975 & 1980 & 1985 \\
\hline - . . . & 100.0 & 100.0 & 100.0 \\
\hline Agriculture, forestry, and fisheries & 13.0 & 12.0 & 11.3 \\
\hline Industrial development $\ldots \ldots \ldots \ldots \ldots \ldots$ & 6.7 & 5.8 & 5.9 \\
\hline Energy $\ldots \ldots \ldots \ldots \ldots \ldots \ldots \ldots \ldots \ldots \ldots \ldots \ldots \ldots$ & 7.5 & 12.4 & 16.3 \\
\hline Health $\ldots \ldots \ldots \ldots \ldots \ldots \ldots \ldots \ldots \ldots \ldots \ldots \ldots \ldots$ & 3.0 & 2.9 & 2.6 \\
\hline Advancement of knowledge 1 ...... & 54.7 & 52.5 & 47.3 \\
\hline Civil space $\ldots \ldots \ldots \ldots \ldots \ldots \ldots \ldots \ldots$ & 7.0 & 5.7 & 6.8 \\
\hline Defense $\ldots \ldots \ldots \ldots \ldots \ldots \ldots \ldots \ldots \ldots \ldots \ldots \ldots$ & 2.2 & 2.3 & 4.1 \\
\hline All others & 5.9 & 6.4 & 5.7 \\
\hline
\end{tabular}

'The category "advancement of knowledge" includes general university funds spent on R\&D and should not be equated with basic research SOURCES Organisation for Economic Co-operation and Development and Japanese national sources for (NSF-adjusted) 1985 data 
Table B-14. National industrial R\&D expenditures: $1965-86$

[Constant 1982 dollars in millions]

\begin{tabular}{|c|c|c|c|}
\hline Year & $\begin{array}{c}\text { Japanese } \\
\text { industrial } R \& D^{\prime}\end{array}$ & $\begin{array}{c}\text { U.S. total } \\
\text { industrial R\&D }\end{array}$ & $\begin{array}{l}\text { U.S. company- } \\
\text { funded R\&D }\end{array}$ \\
\hline 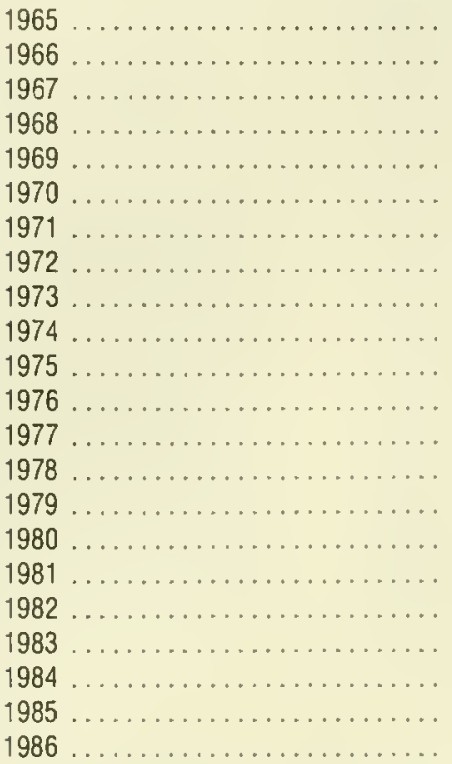 & $\begin{array}{r}\$ 3,043 \\
3,355 \\
4,114 \\
5,207 \\
6,190 \\
7,557 \\
7,781 \\
8,602 \\
9,494 \\
9,592 \\
9,444 \\
9,846 \\
10,424 \\
10,808 \\
12,201 \\
13,859 \\
15,515 \\
16,949 \\
18,991 \\
21,135 \\
24,068 \\
24,370\end{array}$ & $\begin{array}{r}\$ 41,992 \\
44,474 \\
45,590 \\
46,194 \\
46,023 \\
42,986 \\
41,280 \\
42,056 \\
42,893 \\
42,415 \\
40,781 \\
42,805 \\
44,330 \\
46,115 \\
48,652 \\
51,919 \\
55,140 \\
57,995 \\
61,047 \\
66,342 \\
70,350 \\
73,268\end{array}$ & $\begin{array}{r}\$ 19,079 \\
20,641 \\
22,315 \\
23,506 \\
24,779 \\
24,478 \\
24,006 \\
24,812 \\
26,451 \\
27,181 \\
26,272 \\
27,645 \\
28,746 \\
30,622 \\
32,720 \\
35,553 \\
37,705 \\
39,512 \\
41,268 \\
44,842 \\
46,527 \\
47,851\end{array}$ \\
\hline
\end{tabular}

'Because less than 2 percent of Japanese industrial R\&D funds comes from government sources, a separate company-funded R\&D data series has not been provided

SOURCES Government of Japan, Management and Coordination Agency, and the National Science Foundation

Table B-15. National industrial R\&D as a percent of GNP: 1965-86

\begin{tabular}{|c|c|c|c|}
\hline Year & $\begin{array}{c}\text { Japanese } \\
\text { industrial } R \& D\end{array}$ & $\begin{array}{c}\text { U.S. total } \\
\text { industrial R\&D }\end{array}$ & $\begin{array}{l}\text { U.S. company- } \\
\text { funded R\&D }\end{array}$ \\
\hline $1965 \ldots \ldots \ldots \ldots \ldots \ldots \ldots$ & .8 & 2.0 & .9 \\
\hline $1966 \ldots \ldots \ldots \ldots \ldots \ldots$ & .7 & 2.0 & .9 \\
\hline $1967 \ldots \ldots \ldots \ldots \ldots \ldots$ & .8 & 2.0 & 1.0 \\
\hline $1968 \ldots \ldots \ldots \ldots \ldots \ldots \ldots$ & .9 & 2.0 & 1.0 \\
\hline $1969 \ldots \ldots \ldots \ldots \ldots \ldots \ldots$ & 1.0 & 1.9 & 1.0 \\
\hline $1970 \ldots \ldots \ldots \ldots \ldots \ldots$ & 1.1 & 1.8 & 1.0 \\
\hline $1971 \ldots \ldots \ldots \ldots \ldots \ldots$ & 1.1 & 1.7 & 1.0 \\
\hline $1972 \ldots \ldots \ldots \ldots \ldots \ldots \ldots$ & 1.1 & 1.6 & 1.0 \\
\hline $1973 \ldots \ldots \ldots \ldots \ldots \ldots$ & 1.1 & 1.6 & 1.0 \\
\hline $1974 \ldots \ldots \ldots \ldots \ldots \ldots \ldots$ & 1.2 & 1.6 & 1.0 \\
\hline $1975 \ldots \ldots \ldots \ldots \ldots \ldots$ & 1.1 & 1.5 & 1.0 \\
\hline $1976 \ldots \ldots \ldots \ldots \ldots$ & 1.1 & 1.5 & 1.0 \\
\hline $1977 \ldots \ldots \ldots \ldots \ldots \ldots$ & 1.1 & 1.5 & 1.0 \\
\hline $1978 \ldots \ldots \ldots \ldots \ldots \ldots \ldots$ & 1.1 & 1.5 & 1.0 \\
\hline $1979 \ldots \ldots \ldots \ldots \ldots \ldots$ & 1.2 & 1.5 & 1.0 \\
\hline $1980 \ldots \ldots \ldots \ldots$ & 1.3 & 1.6 & 1.1 \\
\hline $1981 \ldots \ldots \ldots \ldots \ldots \ldots \ldots$ & 1.4 & 1.7 & 1.2 \\
\hline $1982 \ldots \ldots \ldots \ldots \ldots \ldots$ & 1.5 & 1.8 & 1.2 \\
\hline $1983 \ldots \ldots$ & 1.7 & 1.9 & 1.3 \\
\hline $1984 \ldots \ldots \ldots \ldots \ldots \ldots \ldots$ & 1.7 & 1.9 & 1.3 \\
\hline $1985 \ldots \ldots \ldots \ldots \ldots \ldots \ldots$ & 1.9 & 2.0 & 1.3 \\
\hline $1986 \ldots \ldots \ldots \ldots \ldots \ldots$ & 1.9 & 2.0 & 1.3 \\
\hline
\end{tabular}

JJapanese industrial R\&D is almost 98 percent company-funded

SOURCES Government of Japan. Management and Coordination Agency, and the National Science Foundation 
Table B-16. Japanese manufacturing R\&D expenditures by industry: selected years

[Constant 1982 dollars in millions]

\begin{tabular}{|c|c|c|c|c|c|c|}
\hline \multirow[b]{2}{*}{ Industry } & \multicolumn{2}{|c|}{1965} & \multicolumn{2}{|c|}{1975} & \multicolumn{2}{|c|}{1985} \\
\hline & Amount & Share & Amount & Share & Amount & Share \\
\hline All manufacturing, total .. & $\$ 2,737$ & $100 \%$ & $\$ 8,613$ & $100 \%$ & $\$ 22,462$ & $100 \%$ \\
\hline Food & 109 & 4 & 259 & 3 & 541 & 2 \\
\hline Textiles & 96 & 4 & 127 & 2 & 254 & 1 \\
\hline Chemicals and allied products .... & 753 & 28 & 1,805 & 21 & 3,794 & 17 \\
\hline Industrial chemicals & 293 & 11 & 860 & 10 & 1,531 & 7 \\
\hline Drugs and medicines. & 176 & 6 & 534 & 6 & 1,385 & 6 \\
\hline Petroleum and coal & 27 & 1 & 96 & 1 & 277 & 1 \\
\hline Rubber $\ldots \ldots \ldots \ldots$ & 43 & 2 & 160 & 2 & 589 & 3 \\
\hline Ceramics $^{1}$. & 66 & 2 & 234 & 3 & 706 & 3 \\
\hline Iron and steel ........... & 178 & 7 & 500 & 6 & 974 & 4 \\
\hline Non-ferrous metals & 88 & 3 & 146 & 2 & 407 & 2 \\
\hline Fabricated metals & 45 & 2 & 165 & 2 & 416 & 2 \\
\hline General machinery ${ }^{2}$ & 214 & 8 & 648 & 8 & 1,551 & 7 \\
\hline Electrical machinery ${ }^{2}$ & 616 & 23 & 2,245 & 26 & 7,853 & 35 \\
\hline Electrical equipment ......... & 240 & 9 & 934 & 11 & 2,497 & 11 \\
\hline $\begin{array}{l}\text { Communications and electronic } \\
\text { equipment }{ }^{2} \ldots \ldots \ldots \ldots \ldots\end{array}$ & 376 & 14 & 1,311 & 15 & 5,357 & 24 \\
\hline Motor vehicles $\ldots . \ldots \ldots$. & 258 & 9 & 1,098 & 13 & 3,230 & 14 \\
\hline $\begin{array}{l}\text { Professional and scientific } \\
\text { instruments } \ldots \ldots \ldots \ldots \ldots\end{array}$ & 65 & 2 & 201 & 2 & 817 & 4 \\
\hline All others $\ldots \ldots \ldots \ldots \ldots$ & 179 & 7 & 929 & 11 & 1,053 & 5 \\
\hline
\end{tabular}

'Stone, clay, and glass products

${ }^{2}$ Note that the Japanese industrial classifications for general machinery and electrical machinery do not correspond to those of the United States except where the US data have been adjusted in this report. In Japan, computers are classified under electrical machinery as communcations and electronic equipment, whereas in the United States, they are classified under general machinery For more detal, see appendix $A$.

NOTE Because of rounding, figures may not add to totals shown Percentages based an natıonal currencies.

SOURCE: Government of Japan, Management and Coordinatıon Agency 
Table B-17. Manufacturing R\&D activity by industry: 1985

[Constant 1982 dollars in millions]

\begin{tabular}{|c|c|c|c|c|c|c|c|}
\hline \multirow[b]{2}{*}{ Industry } & \multicolumn{2}{|c|}{$\begin{array}{l}\text { Company-funded R\&D } \\
\text { expenditures }\end{array}$} & \multirow[t]{2}{*}{$\begin{array}{l}\text { Japan/U.S. ratio } \\
\text { (percent) }\end{array}$} & \multicolumn{2}{|c|}{$\begin{array}{l}\text { R\&D expenditures as a } \\
\text { percent of net sales }\end{array}$} & \multicolumn{2}{|c|}{$\begin{array}{l}\text { Number of scientists and } \\
\text { engineers engaged in R\&D } \\
\text { per } 10,000 \text { employed }^{1}\end{array}$} \\
\hline & Japan & United States & & Japan & United States & Japan & United States \\
\hline All manufacturing, total....... & $\$ 22,462$ & $\$ 45,298$ & 50 & 2.7 & 2.8 & 468 & 400 \\
\hline $\begin{array}{l}\text { Food } \ldots \ldots \ldots \ldots \ldots \ldots \ldots \ldots \ldots \ldots \ldots \\
\text { Textiles } \ldots \ldots \ldots \ldots \ldots \ldots \ldots \ldots \\
\text { Chemicals and allied products } \ldots \ldots \ldots \ldots\end{array}$ & $\begin{array}{r}541 \\
254 \\
3.794 \\
\end{array}$ & $\begin{array}{r}937 \\
135 \\
7,513 \\
\end{array}$ & $\begin{array}{r}58 \\
188 \\
51\end{array}$ & $\begin{array}{r}.8 \\
1.2 \\
3.8\end{array}$ & $\begin{array}{r}.4 \\
.5 \\
4.7 \\
\end{array}$ & $\begin{array}{l}225 \\
213 \\
784\end{array}$ & $\begin{array}{r}\text { NA } \\
40 \\
550\end{array}$ \\
\hline $\begin{array}{l}\text { Industrial chemicals... } \\
\text { Drugs and medicines.. }\end{array}$ & $\begin{array}{l}1,531 \\
1,385 \\
\end{array}$ & $\begin{array}{l}3,254 \\
3,189\end{array}$ & $\begin{array}{l}47 \\
43\end{array}$ & $\begin{array}{l}2.8 \\
7.0\end{array}$ & $\begin{array}{l}4.0 \\
8.4\end{array}$ & $\begin{array}{l}711 \\
796\end{array}$ & $\begin{array}{l}420 \\
N A\end{array}$ \\
\hline 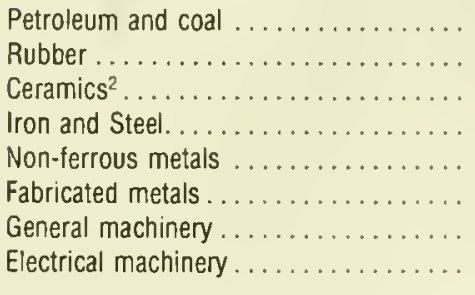 & $\begin{array}{r}277 \\
589 \\
706 \\
974 \\
407 \\
416 \\
1,551 \\
7,853 \\
\end{array}$ & $\begin{array}{r}1,894 \\
750 \\
437 \\
334 \\
348 \\
524 \\
31,990 \\
315,575 \\
\end{array}$ & $\begin{array}{r}15 \\
79 \\
162 \\
292 \\
117 \\
79 \\
78 \\
50 \\
\end{array}$ & $\begin{array}{l}.4 \\
2.2 \\
2.6 \\
1.9 \\
1.9 \\
1.6 \\
2.7 \\
5.1 \\
\end{array}$ & $\begin{array}{r}.7 \\
2.2 \\
1.3 \\
.5 \\
1.4 \\
1.3 \\
2.3 \\
6.4\end{array}$ & $\begin{array}{l}394 \\
363 \\
355 \\
177 \\
316 \\
260 \\
425 \\
767 \\
\end{array}$ & $\begin{array}{c}210 \\
\text { NA } \\
50 \\
150 \\
180 \\
\text { NA } \\
4520 \\
4500 \\
4\end{array}$ \\
\hline $\begin{array}{l}\text { Electrical equipment........... } \\
\text { Communications and electronic } \\
\text { equipment................. }\end{array}$ & $\begin{array}{l}2,497 \\
5,357\end{array}$ & $\begin{array}{r}1,817 \\
313,758\end{array}$ & $\begin{array}{r}137 \\
39\end{array}$ & $\begin{array}{l}4.8 \\
5.3\end{array}$ & $\begin{array}{l}2.9 \\
7.6\end{array}$ & $\begin{array}{l}647 \\
836 \\
\end{array}$ & $\begin{array}{l}\text { NA } \\
4550\end{array}$ \\
\hline $\begin{array}{l}\text { Motor vehicles .................. } \\
\text { Professional and scientific } \\
\text { instruments .................. } \\
\text { Aircraft and missiles } \ldots \ldots \ldots \ldots \ldots \ldots\end{array}$ & $\begin{array}{c}3,230 \\
817 \\
\text { NA }\end{array}$ & $\begin{array}{l}5,469 \\
4,249 \\
3,776\end{array}$ & $\begin{array}{r}59 \\
19 \\
\text { NA }\end{array}$ & $\begin{array}{l}3.0 \\
4.5 \\
\text { NA }\end{array}$ & $\begin{array}{l}3.2 \\
9.0 \\
4.1\end{array}$ & $\begin{array}{l}331 \\
664 \\
\text { NA }\end{array}$ & $\begin{array}{c}280 \\
N A \\
1,060\end{array}$ \\
\hline
\end{tabular}

${ }^{1}$ Numbers ol U S scientists and engineers engaged in R\&D are in full-time equivalents, Japanese are not.

2Stone, clay, and glass products

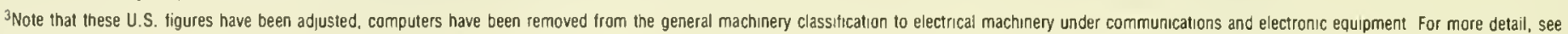
appendix $A$

4These figures are not comparable to the Japanese because they represent different SIC product groupings

NOTE: Percentages calculated from unrounded figures NA Not separately avallable See appendix A

SOURCES Government of Japan, Management and Coordination Agency, and the National Science Foundation 
Table B-18. Shares of manufacturing

$R \& D$ accounted for by the five largest

R\&D firms by industry: 1985

[Percent]

\begin{tabular}{|c|c|c|}
\hline industry & Japan & $\begin{array}{l}\text { United } \\
\text { States }\end{array}$ \\
\hline $\begin{array}{l}\text { All } \\
\text { manufacturing }\end{array}$ & 18 & 23 \\
\hline $\begin{array}{l}\text { Food } \ldots \ldots \ldots \\
\text { Textiles ........ }\end{array}$ & $\begin{array}{l}32 \\
47\end{array}$ & $\begin{array}{r}37 \\
145\end{array}$ \\
\hline Chemicals and & 17 & 31 \\
\hline $\begin{array}{l}\text { Industrial } \\
\text { chemicals .. }\end{array}$ & 31 & 70 \\
\hline $\begin{array}{l}\text { Drugs and } \\
\text { medicines }\end{array}$ & 32 & 37 \\
\hline $\begin{array}{l}\text { Petroleum and } \\
\text { coal ......... }\end{array}$ & 71 & 71 \\
\hline Rubber $\ldots \ldots$. & 60 & 62 \\
\hline Ceramics $^{2}$ & 35 & 157 \\
\hline $\begin{array}{l}\text { Iron and steel ... } \\
\text { Nonferrous }\end{array}$ & 78 & 141 \\
\hline metals ....... & 57 & ${ }^{1} 56$ \\
\hline $\begin{array}{l}\text { Fabricated metals } \\
\text { General }\end{array}$ & 25 & ${ }^{1} 36$ \\
\hline $\begin{array}{c}\text { machinery } \ldots . . . \\
\text { Electrical }\end{array}$ & 28 & 240 \\
\hline machinery & 45 & 249 \\
\hline $\begin{array}{l}\text { Communications } \\
\text { and electronic } \\
\text { equipment .... }\end{array}$ & 56 & 355 \\
\hline $\begin{array}{l}\text { Motor vehicies ... } \\
\text { Professional and } \\
\text { scientific } \\
\text { instruments ... }\end{array}$ & 69 & 96 \\
\hline $\begin{array}{l}\text { Aircraft and } \\
\text { missiles ...... }\end{array}$ & NA & 64 \\
\hline
\end{tabular}

1Four largest firms only

${ }^{2}$ Stone, clay, and glass products

${ }^{3}$ Note that the U.S figures have been adjusted, computers have been removed from the general machinery classification to electrical machinery under communications equipment and electronic components. For more detall, see appendix $A$

NOTE NA: Not separately avallable

SOURCES: Government of Japan, Management and Coordunation Agency, and the National Science Foundation
Table B-19. Number of industrial scientists and engineers engaged in R\&D: $1965-85^{1}$

[In thousands]

\begin{tabular}{|c|c|c|c|}
\hline & Year & Japan & $\begin{array}{l}\text { United } \\
\text { States }\end{array}$ \\
\hline 1965 & $\ldots \ldots \ldots \ldots$ & 59.0 & 348.4 \\
\hline 1966 & $\ldots \ldots \ldots \ldots$ & 65.4 & 360.2 \\
\hline 1967 & $\ldots \ldots \ldots \ldots$ & 69.2 & 372.0 \\
\hline 1968 & $\ldots \ldots \ldots$ & 81.7 & 381.9 \\
\hline 1969 & $\ldots \ldots \ldots \ldots$ & 82.5 & 385.6 \\
\hline 1970 & $\ldots \ldots \ldots \ldots$ & 94.1 & 375.6 \\
\hline 1971 & $\ldots \ldots \ldots \ldots$ & 111.2 & 358.6 \\
\hline 1972 & $\ldots \ldots \ldots \ldots$ & 112.8 & 354.0 \\
\hline 1973 & $\ldots \ldots \ldots$ & 124.8 & 358.9 \\
\hline 1974 & $\ldots \ldots \ldots \ldots$ & 130.7 & 361.7 \\
\hline 1975 & $\ldots$ & 146.6 & 363.9 \\
\hline 1976 & $\ldots$ & 145.2 & 373.6 \\
\hline 1977 & $\ldots \ldots \ldots \ldots$ & 151.4 & 393.6 \\
\hline 1978 & $\ldots \ldots \ldots$ & 153.7 & 414.2 \\
\hline 1979 & & 157.3 & 437.3 \\
\hline 1980 & & 184.9 & 498.8 \\
\hline 1981 & $\ldots \ldots \ldots \ldots$ & 157.3 & 437.3 \\
\hline 1982 & $\ldots \ldots \ldots \ldots$ & 192.9 & 516.0 \\
\hline 1983 & $\ldots \ldots \ldots \ldots$ & 201.1 & 533.3 \\
\hline 1984 & $\ldots \ldots \ldots$ & 223.9 & 552.4 \\
\hline 1985 & $\ldots \ldots \ldots \ldots$ & 231.1 & 570.3 \\
\hline
\end{tabular}

${ }^{1}$ Numbers of U.S. Scientists and enguneers are in full-tume equivalents, Japanese are not

SOURCES Government of Japan, Management and Coordination Agency, and the National Science Foundation 
Table B-20. Higher education R\&D expenditures: 1965-86

[Constant 1982 dollars in millions]

\begin{tabular}{|c|c|c|c|c|}
\hline \multirow[b]{2}{*}{ Year } & \multicolumn{2}{|c|}{ Japan } & \multicolumn{2}{|c|}{ United States ${ }^{1}$} \\
\hline & Amount & $\begin{array}{c}\text { As a share of } \\
\text { total R\&D }\end{array}$ & Amount & $\begin{array}{c}\text { As a share of } \\
\text { total R\&D }\end{array}$ \\
\hline $1965 \ldots \ldots \ldots \ldots \ldots \ldots \ldots \ldots$ & $\$ 2,214$ & $36 \%$ & $\$ 6,231$ & $11 \%$ \\
\hline $1966 \ldots \ldots \ldots \ldots \ldots \ldots \ldots \ldots$ & 2,319 & 35 & 6,750 & 11 \\
\hline $1967 \ldots \ldots \ldots \ldots \ldots \ldots \ldots \ldots$ & 2,491 & 33 & 7,220 & 11 \\
\hline $1968 \ldots$ & 2,669 & 30 & 7,712 & 12 \\
\hline $1969 \ldots$ & 2,948 & 28 & 7,526 & 12 \\
\hline $1970 \ldots \ldots \ldots \ldots \ldots$ & 3,358 & 27 & 7,406 & 12 \\
\hline $1971 \ldots \ldots \ldots \ldots \ldots \ldots \ldots \ldots$ & 3,681 & 28 & 7,366 & 12 \\
\hline $1972 \ldots \ldots$. & 3,940 & 27 & 7,345 & 12 \\
\hline $1973 \ldots$ & 4,187 & 26 & 7,655 & 12 \\
\hline $1974 \ldots \ldots \ldots \ldots \ldots$ & 4,332 & 26 & 7,454 & 12 \\
\hline $1975 \ldots \ldots \ldots \ldots \ldots \ldots \ldots$ & 4,707 & 28 & 7.643 & 13 \\
\hline $1976 \ldots \ldots \ldots \ldots \ldots \ldots \ldots$ & 4,886 & 28 & 7,854 & 13 \\
\hline $1977 \ldots \ldots \ldots \ldots \ldots \ldots \ldots \ldots$ & 5,002 & 28 & 8,132 & 13 \\
\hline $1978 \ldots \ldots \ldots \ldots \ldots \ldots \ldots$ & 5,430 & 29 & 8,843 & 13 \\
\hline $1979 \ldots \ldots \ldots \ldots \ldots \ldots \ldots$ & 5,761 & 28 & 9,366 & 13 \\
\hline $1980 \ldots \ldots \ldots \ldots$ & 5,910 & 26 & 9,802 & 13 \\
\hline $1981 \ldots$ & 6,179 & 24 & 9,983 & 13 \\
\hline $1982 \ldots$ & 6,464 & 24 & 9,755 & 12 \\
\hline $1983 \ldots$ & 6,870 & 23 & 10,116 & 12 \\
\hline $1984 \ldots \ldots$ & 7,094 & 22 & 10,741 & 12 \\
\hline $1985 \ldots \ldots \ldots \ldots \ldots$ & 7,252 & 20 & 11,669 & 12 \\
\hline $1986 \ldots \ldots \ldots \ldots \ldots \ldots \ldots$ & 7,297 & 20 & 12,656 & 12 \\
\hline
\end{tabular}

${ }^{1}$ Includes higher education institutions and federally funded research and development centers.

NOTE Percentages caiculated from national currencies

SOURCES Government of Japan. Management and Coordination Agency, and the National Science foundation
Table B-21. Distribution of higher education R\&D expenditures among fields: 1985

[Percent]

\begin{tabular}{c|r|r}
\hline \multicolumn{1}{c|}{ Field } & Japan & $\begin{array}{r}\text { United } \\
\text { States }\end{array}$ \\
\hline Total .......... & 100.0 & 100.0 \\
\cline { 2 - 3 } Agriculture ....... & 4.8 & 10.8 \\
Natural sciences ... & 9.0 & 43.2 \\
Engineering ...... & 20.7 & 14.6 \\
Medical sciences ... & 25.5 & 23.7 \\
Social sciences ... & 13.0 & 25.8 \\
All other fields .... & 326.9 & 1.9 \\
\hline
\end{tabular}

'Law, political science, and "other social sciences "

${ }^{2}$ Including psychology

${ }^{3}$ Home economics, education, and others

NOTE. Because of rounding. percentages may not add to 100

SOURCES: Government of Japan, Management and Coordination Agency, and the National Science Foundation

\section{Table B-22. Distribution of academic separately budgeted R\&D by field:} 1982

[Percent]

\begin{tabular}{|c|c|c|}
\hline Total & 100.0 & 100.0 \\
\hline Engineering & 20.2 & 14.1 \\
\hline Physical sciences ... & 35.9 & 12.1 \\
\hline $\begin{array}{l}\text { Environmental } \\
\text { sciences } \ldots \ldots \ldots \text {. }\end{array}$ & 6.8 & 7.4 \\
\hline $\begin{array}{l}\text { Math and computer } \\
\text { science } \ldots \ldots \ldots\end{array}$ & 1.0 & 3.4 \\
\hline Life sciences ...... & 26.1 & 53.6 \\
\hline Social sciences ..... & 1.8 & 4.2 \\
\hline Psychology ....... & .6 & 1.8 \\
\hline All other ${ }^{\prime} . . . \ldots$. & 7.7 & 3.3 \\
\hline
\end{tabular}

'Protessional and vocational studies, arts and humanities NOTE Because of rounding, percentages may not add to 100 SOURCE Ben R Martin and John Irvine. An International Comparison of Government Funding of Academic and Academically Relared Research. Science Policy and Research Evaluation Group. Science Policy Research Unit. University of Sussex United Kingdom Advisory Board for the Research Councils, 1986
Table B-23. First-university degrees by field and as a proportion of the 22-yearold population: 1985

\begin{tabular}{|c|c|c|c|c|}
\hline \multirow[b]{2}{*}{ Field } & \multicolumn{2}{|c|}{ Japan } & \multicolumn{2}{|c|}{ United States } \\
\hline & Number & Proportion & Number & Proportion \\
\hline Total $\ldots \ldots \ldots \ldots$ & 373,302 & $22.6 \%$ & $1,066,439$ & $25.3 \%$ \\
\hline Natural sciences & 12,698 & .8 & 120,168 & 2.9 \\
\hline Engineering & 71,396 & 4.3 & 77,871 & 1.8 \\
\hline Agriculture & 13,450 & .8 & 15,879 & .4 \\
\hline Social sciences ${ }^{1}$. & 149,715 & 9.1 & 107,821 & 2.6 \\
\hline 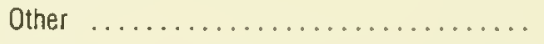 & 126,043 & 7.6 & 744,700 & 17.7 \\
\hline
\end{tabular}

'There is not a one-10-one correspondence between social science disciplines in Japan and the United States NOTE Because of rounding, percentages may not add to totals shown

SOURCES: Government of Japan, Ministry of Education, Science, and Culture, Basic Education Survey 1985, and the National Science Foundation 
Table B-24. Doctoral degrees by field and as a proportion of the 27 -year-old population: 1984 or 1985

\begin{tabular}{|c|c|c|c|c|}
\hline \multirow[b]{2}{*}{ Field } & \multicolumn{2}{|c|}{ Japan (1984) } & \multicolumn{2}{|c|}{ United States (1985) } \\
\hline & Number & Proportion & Number & Proportion \\
\hline Natural sciences and engineering, total ... & 2,712 & $0.2 \%$ & 12,101 & $0.3 \%$ \\
\hline $\begin{array}{l}\text { Natural sciences ... } \\
\text { Engineering .... } \\
\text { Agriculture . . . . }\end{array}$ & $\begin{array}{r}807 \\
1,291 \\
614\end{array}$ & $\begin{array}{l}.1 \\
.1 \\
1\end{array}$ & $\begin{array}{l}7,793 \\
3,251 \\
1,057\end{array}$ & $\begin{array}{l}.2 \\
.1 \\
1\end{array}$ \\
\hline $\begin{array}{l}\text { Other }^{2} \ldots \ldots \ldots \\
\text { All fields . . . . . }\end{array}$ & $\begin{array}{r}34,765 \\
7,477\end{array}$ & $\begin{array}{l}.3 \\
.5\end{array}$ & $\begin{array}{l}20,871 \\
32,971\end{array}$ & $\begin{array}{l}.5 \\
.7\end{array}$ \\
\hline
\end{tabular}

'Less than 0.05 percent

${ }^{2}$ Including social sciences, humanities, and health-related fields

${ }^{3}$ Of these Japanese doctorates, 4,502 are in health-related fields.

NOTE: Because ot rounding, percentages may not add to totals shown.

SOURCES Government ot Japan. Science and Technology Agency, and the National Science Foundation

Table B-25. Trends in scientific literature outputs: selected years

\begin{tabular}{|c|c|c|c|}
\hline Scientific literature outputs & 1972 & 1977 & 1982 \\
\hline \multicolumn{4}{|l|}{ Journal articles } \\
\hline Japan ........ & 105,200 & 161,000 & 227,400 \\
\hline United States $\ldots \ldots \ldots \ldots \ldots \ldots \ldots$ & 365,800 & 457,700 & 587,900 \\
\hline World ........ & $1,025,200$ & $1,339,200$ & $1,741,000$ \\
\hline \multicolumn{4}{|l|}{ Technical reports } \\
\hline Japan ....... & 3,370 & 5,400 & 10,320 \\
\hline United States & 51,890 & 49,810 & 49,010 \\
\hline World ...... & 95,500 & 101,300 & 130,000 \\
\hline \multicolumn{4}{|l|}{ Conference papers } \\
\hline Japan ........ & 7,210 & 15,050 & 26,800 \\
\hline United States & 33,600 & 50,330 & 90,000 \\
\hline World ...... & 75,400 & 121,500 & 221,500 \\
\hline
\end{tabular}

SOURCE- Mitsubıshı Sogo Kenkyusho (Mitsubishı Research Instıtute), Kagaku Gitılsu Joho no Kokusar-teki Ryutsu no Arıkata ni Kan-suru. 1984

Table B-26. Japanese-invented U.S. patents by selected patent classes: ${ }^{1}$ 1975-84

\begin{tabular}{|c|c|c|c|}
\hline & Patent classification & $\begin{array}{c}\text { Number of } \\
\text { patents }\end{array}$ & $\begin{array}{c}\text { Share of } \\
\text { patent class }\end{array}$ \\
\hline & Internal combustion engines & 2,706 & $31.5 \%$ \\
\hline 430 & Radiation imagery ..... & 2,273 & 34.7 \\
\hline 354 & Photography ... & 2,167 & 52.5 \\
\hline 424 & Bioaffecting drugs $\ldots \ldots \ldots \ldots \ldots \ldots \ldots \ldots \ldots \ldots \ldots \ldots \ldots$ & 1,819 & 10.2 \\
\hline 428 & 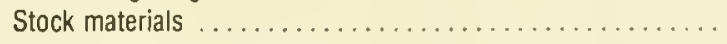 & 1,696 & 16.9 \\
\hline 350 & 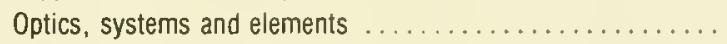 & 1,493 & 24.7 \\
\hline 358 & Pictorial communication ...... & 1,431 & 27.6 \\
\hline 360 & Dynamic magnetic information storage .. & 1,244 & 37.3 \\
\hline 355 & Photocopying $\ldots \ldots \ldots \ldots \ldots \ldots \ldots \ldots \ldots \ldots \ldots \ldots \ldots \ldots \ldots \ldots \ldots \ldots \ldots$ & 1,204 & 35.6 \\
\hline 364 & Electrical computers and data processing systems $\ldots \ldots \ldots$ & 1,202 & 15.2 \\
\hline 204 & Chemical, electrical, and wave energy $\ldots \ldots \ldots \ldots$. & 1,153 & 13.7 \\
\hline 340 & Communications, electrical . ................... & 1,046 & 15.2 \\
\hline
\end{tabular}

'Those classes for which the total number of patents exceeded 1,000.

SOURCE Francis Narin and Dominic Olivastro, Patent Activity and Citation Analysis Using U.S. POC Classitication, interım report by Computer Honzons, Inc., to the National Science Foundation, September 1986 
Table B-27. Output per worker-hour in manufacturing: 1965-85

[Index: $1977=100$ ]

\begin{tabular}{|c|c|c|}
\hline Year & Japan & $\begin{array}{l}\text { United } \\
\text { States }\end{array}$ \\
\hline $1965 \ldots \ldots \ldots \ldots$ & 35.0 & 76.6 \\
\hline $1966 \ldots \ldots \ldots \ldots$ & 38.5 & 77.4 \\
\hline $1967 \ldots \ldots \ldots \ldots$ & 44.2 & 77.4 \\
\hline$\ldots \ldots \ldots \ldots$ & 49.8 & 79.8 \\
\hline $1969 \ldots$ & 57.5 & 80.8 \\
\hline $1970 \ldots \ldots \ldots \ldots$ & 64.8 & 80.8 \\
\hline $1971 \ldots \ldots \ldots \ldots$ & 68.6 & 85.3 \\
\hline $1972 \ldots \ldots \ldots \ldots$ & 75.3 & 89.0 \\
\hline$\ldots \ldots$ & 83.1 & 93.4 \\
\hline 1974 & 86.5 & 90.6 \\
\hline 1975 & 87.7 & 92.9 \\
\hline $1976 \ldots \ldots \ldots \ldots$ & 94.3 & 97.1 \\
\hline$\ldots \ldots$ & 100.0 & 100.0 \\
\hline 1978 & 108.0 & 101.5 \\
\hline 1979 & 114.8 & 101.4 \\
\hline 1980 & 122.7 & 101.4 \\
\hline$\ldots \ldots \ldots$ & 127.2 & 103.6 \\
\hline$\ldots \ldots \ldots$ & 135.0 & 105.9 \\
\hline $1983 \ldots \ldots \ldots \ldots$ & 142.3 & 112.0 \\
\hline $1984 \ldots \ldots \ldots \ldots$ & 152.5 & 116.6 \\
\hline $1985 \ldots \ldots \ldots \ldots$ & 163.7 & 121.7 \\
\hline 1986 (est.) ....... & 168.2 & 126.0 \\
\hline
\end{tabular}

SOURCE U S Department of Labor, Bureau of Labor Statistics

Table B-28. Japanese manufacturing use of technical know-how by selected industries: 1975 and 1985

[Constant 1982 dollars in millions]

\begin{tabular}{|c|c|c|c|c|c|c|c|c|}
\hline \multirow[b]{2}{*}{ Industry } & \multicolumn{4}{|c|}{1975} & \multicolumn{4}{|c|}{1985} \\
\hline & Payments & Receipts & $\begin{array}{l}\text { Receipts/ } \\
\text { payments }\end{array}$ & $\begin{array}{c}\text { Payments/ } \\
\text { R\&D }\end{array}$ & Payments & Receipts & $\begin{array}{l}\text { Receipts/ } \\
\text { payments }\end{array}$ & $\begin{array}{c}\text { Payments/ } \\
\text { R\&D }\end{array}$ \\
\hline All manufacturing $\ldots . .$. & 924 & 330 & 36 & 11 & 1.169 & 833 & 72 & 5 \\
\hline $\begin{array}{l}\text { Food } \ldots \ldots \ldots \ldots \ldots \\
\text { Textiles } \ldots \ldots \ldots \ldots \ldots \ldots \\
\text { Chemicals and allied } \\
\quad \text { products } \ldots \ldots \ldots \ldots \ldots\end{array}$ & $\begin{array}{r}\$ 22 \\
13 \\
151 \\
\end{array}$ & $\begin{array}{r}\$ 3 \\
7 \\
121 \\
\end{array}$ & $\begin{array}{l}15 \% \\
59 \\
80 \\
\end{array}$ & $\begin{array}{c}8 \% \\
10 \\
8 \\
\end{array}$ & $\begin{array}{r}\$ \quad 42 \\
13 \\
\\
\\
151 \\
\end{array}$ & $\begin{array}{r}\$ 25 \\
16 \\
155 \\
\end{array}$ & $\begin{array}{l}59 \% \\
122 \\
102 \\
\end{array}$ & $\begin{array}{l}8 \% \\
5 \\
4\end{array}$ \\
\hline $\begin{array}{l}\text { Industrial chemicals ..... } \\
\text { Drugs and medicines .... }\end{array}$ & $\begin{array}{l}96 \\
32\end{array}$ & $\begin{array}{c}101 \\
7\end{array}$ & $\begin{array}{r}105 \\
23\end{array}$ & $\begin{array}{r}11 \\
6\end{array}$ & $\begin{array}{l}55 \\
53\end{array}$ & $\begin{array}{l}80 \\
53\end{array}$ & $\begin{array}{l}146 \\
100\end{array}$ & $\begin{array}{l}4 \\
4\end{array}$ \\
\hline $\begin{array}{l}\text { Petroleum and coal ........ } \\
\text { Rubber } \ldots \ldots \ldots \ldots \\
\text { Ceramics }{ }^{1} \ldots \ldots \ldots \\
\text { Iron and steel } \ldots \ldots \ldots \\
\text { Nonferrous metals } \ldots \ldots \ldots \\
\text { Fabricated metals } \ldots \ldots \ldots \\
\text { General machinery } \ldots \ldots \\
\text { Electrical machinery } \ldots \ldots\end{array}$ & $\begin{array}{r}18 \\
20 \\
42 \\
34 \\
19 \\
10 \\
129 \\
214\end{array}$ & $\begin{array}{r}\text { NA } \\
4 \\
10 \\
67 \\
3 \\
3 \\
25 \\
41\end{array}$ & $\begin{array}{r}\text { NA } \\
18 \\
24 \\
197 \\
15 \\
34 \\
20 \\
19\end{array}$ & $\begin{array}{r}18 \\
13 \\
18 \\
7 \\
13 \\
6 \\
20 \\
10\end{array}$ & $\begin{array}{r}21 \\
26 \\
131 \\
19 \\
21 \\
16 \\
99 \\
341 \\
\end{array}$ & $\begin{array}{r}2 \\
16 \\
38 \\
106 \\
8 \\
10 \\
47 \\
241\end{array}$ & $\begin{array}{r}11 \\
61 \\
29 \\
558 \\
38 \\
61 \\
48 \\
71\end{array}$ & $\begin{array}{r}8 \\
4 \\
19 \\
2 \\
5 \\
4 \\
6 \\
4\end{array}$ \\
\hline $\begin{array}{l}\text { Electrical equipment ...... } \\
\text { Communications and } \\
\text { electronic equipment ... }\end{array}$ & $\begin{array}{l}117 \\
97\end{array}$ & $\begin{array}{l}18 \\
23\end{array}$ & $\begin{array}{l}15 \\
24\end{array}$ & $\begin{array}{l}13 \\
7\end{array}$ & $\begin{array}{r}98 \\
244 \\
\end{array}$ & $\begin{array}{r}72 \\
169 \\
\end{array}$ & $\begin{array}{l}74 \\
69\end{array}$ & $\begin{array}{l}4 \\
5\end{array}$ \\
\hline $\begin{array}{l}\text { Motor vehicles .......... } \\
\text { Professional and scientific } \\
\text { instruments ........... }\end{array}$ & $\begin{array}{l}77 \\
16\end{array}$ & $\begin{array}{l}24 \\
1\end{array}$ & $\begin{array}{l}31 \\
8\end{array}$ & $\begin{array}{l}7 \\
8\end{array}$ & $\begin{array}{l}46 \\
20\end{array}$ & $\begin{array}{r}105 \\
7\end{array}$ & $\begin{array}{r}228 \\
34\end{array}$ & $\begin{array}{l}1 \\
3\end{array}$ \\
\hline
\end{tabular}

'Stone, clay, and glass products

SOURCES Government of Japan, Science and Technology Agency and Management and Coordination Agency 
Table B-29. Japanese trade balance with the United States in technologyintensive products: ${ }^{1} 1965-85$

[Current dollars in millions]

\begin{tabular}{|c|c|c|c|}
\hline Year & Balance & $\begin{array}{c}\text { Exports to United } \\
\text { States }\end{array}$ & $\begin{array}{l}\text { Imports from } \\
\text { United States }\end{array}$ \\
\hline 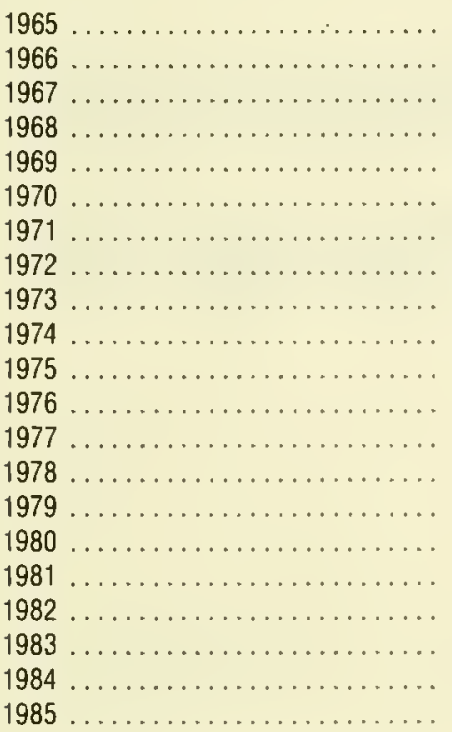 & $\begin{array}{r}143.4 \\
304.2 \\
279.9 \\
482.9 \\
724.8 \\
555.0 \\
822.1 \\
1,204.6 \\
1,174.5 \\
692.2 \\
962.6 \\
2,848.3 \\
3,444.0 \\
4,159.1 \\
2,819.6 \\
3,108.3 \\
5,536.8 \\
5,204.7 \\
7,035.3 \\
13,323.1 \\
13,024.0\end{array}$ & $\begin{array}{r}501.8 \\
712.1 \\
784.1 \\
1,104.1 \\
1,502.2 \\
1,732.8 \\
2,064.8 \\
2,538.9 \\
2,869.5 \\
3,028.5 \\
2,907.6 \\
5,084.2 \\
5,823.1 \\
7,238.8 \\
7,126.5 \\
8,412.6 \\
11,747.9 \\
11,428.6 \\
14,300.0 \\
21,345.0 \\
21,252.2\end{array}$ & $\begin{array}{r}\$ 358.4 \\
407.9 \\
504.2 \\
621.2 \\
795.4 \\
1,177.8 \\
1,242.6 \\
1,334.3 \\
1,695.1 \\
2,336.4 \\
1,945.0 \\
2,236.0 \\
2,379.1 \\
3,079.7 \\
4,306.9 \\
5,304.3 \\
6,211.1 \\
6,223.8 \\
7,264.8 \\
8,021.9 \\
8,228.1\end{array}$ \\
\hline
\end{tabular}

'Technology-intensive products are defined as those for which U.S. A\&D expenditures exceed 2.36 percent of value-added (DOC2 and Organisation for Economic Co-operation and Development definition). Data reflect information from 24 reporting countries on exports to, and imports from, each of nearly 200 partner countries.

SOURCE: Natıonal Science Foundation. DRI Special Tabulations of International Trade, 1987
Table B-30. World export shares of technology-intensive products: ${ }^{1}$ 1965-85

[Percent]

\begin{tabular}{|c|c|c|}
\hline Year & Japan & $\begin{array}{l}\text { United } \\
\text { States }\end{array}$ \\
\hline $1965 \ldots \ldots \ldots$ & 7.2 & 27.5 \\
\hline $1966 \ldots \ldots \ldots \ldots$ & 8.3 & 27.1 \\
\hline $1967 \ldots \ldots \ldots \ldots$ & 8.5 & 28.2 \\
\hline $1968 \ldots \ldots \ldots \ldots$ & 9.5 & 29.1 \\
\hline $1969 \ldots \ldots \ldots \ldots$ & 10.7 & 27.8 \\
\hline $1970 \ldots \ldots \ldots \ldots$ & 10.9 & 27.0 \\
\hline $1971 \ldots \ldots \ldots \ldots$ & 11.6 & 26.2 \\
\hline $1972 \ldots \ldots \ldots \ldots$ & 12.7 & 23.7 \\
\hline $1973 \ldots \ldots \ldots \ldots$ & 12.4 & 23.7 \\
\hline $1974 \ldots \ldots \ldots \ldots$ & 12.0 & 24.4 \\
\hline$\ldots \ldots \ldots$ & 11.6 & 24.5 \\
\hline $1976 \ldots$ & 13.7 & 23.5 \\
\hline 1977 & 14.5 & 22.0 \\
\hline 1978 & 15.2 & 21.3 \\
\hline 1979 & 13.6 & 21.9 \\
\hline 1980 & 14.3 & 22.9 \\
\hline $1981 \ldots \ldots$ & 17.4 & 25.0 \\
\hline $1982 \ldots \ldots \ldots \ldots$ & 16.2 & 24.7 \\
\hline $1983 \ldots \ldots \ldots \ldots$ & 17.8 & 25.1 \\
\hline $1984 \ldots \ldots \ldots$ & 20.2 & 25.2 \\
\hline $1985 \ldots \ldots \ldots \ldots$ & 19.4 & 24.2 \\
\hline
\end{tabular}

'Technolagy-intensive products are defined as those for which U S R\&D expendifures exceed 236 percent of value-added (DOC2 and Organisation for Economic Co-operation and Development detintion). Data reflect information from 24 reporting countries on exports 10, and impons from, each of nearly 200 partner countries

SOURCE. National Science Foundation, ORI Special Tabulations of International Trade. 1987 



\section{japanese government research programs}

Table C-1. ERATO ${ }^{1}$ projects adopted through 1986

\begin{tabular}{|c|c|c|}
\hline Project & Period & Purpose \\
\hline Ultrafine particles & $1981-86$ & $\begin{array}{l}\text { To explore the characteristics of ultrafine particles for applications in recording media such as magnetic } \\
\text { memories, light absorbers, catalysts, and filters. }\end{array}$ \\
\hline $\begin{array}{l}\text { Amorphous and intercalation } \\
\text { compound }\end{array}$ & $1981-86$ & $\begin{array}{l}\text { To design and synthesize new inorganic materials for industrial use by modifying the atomic configuration } \\
\text { of existing metals, semiconductors, and ceramics. }\end{array}$ \\
\hline Fine polymers & $1981-86$ & $\begin{array}{l}\text { To develop a new generation of synthetic polymers by taking as models the sophisticated functional } \\
\text { capabilities of living organisms. }\end{array}$ \\
\hline Perfect crystals & $1981-86$ & $\begin{array}{l}\text { To develop a new generation of semiconductors by combining perfect crystal growth technology with static } \\
\text { induction transistor technology. }\end{array}$ \\
\hline Bioholonics & $1982-87$ & $\begin{array}{l}\text { To study "holonic" systems in biological organisms in which molecules, cell tissues, and organs interact } \\
\text { cooperatively at various levels of organization; and to build models of such systems. }\end{array}$ \\
\hline Bio-information transfer & $1983-88$ & $\begin{array}{l}\text { To elucidate the mechanisms of action of neuroactive substances, such as prostaglandins and leukotrienes, } \\
\text { which play a crucial role in intercellular information transter. The project aims to apply these mechanisms } \\
\text { to medical problems and information technology. }\end{array}$ \\
\hline Superbugs & $1984-89$ & $\begin{array}{l}\text { To search for micro-organisms that grow under extreme environmental conditions such as high acidity, } \\
\text { temperature, salinity, and pressure; and to analyze their tolerance mechanisms and metabolic pathways. A } \\
\text { possible result may be new bioreactors that can operate at higher temperatures. }\end{array}$ \\
\hline Solid-state surface & $1985-90$ & $\begin{array}{l}\text { Understand the behavior of atoms and molecules on the surface of solids, to investigate methods for the } \\
\text { chemical processing of surfaces at the molecular level, to synthesize and separate matters, and to explore } \\
\text { the possibilities for the composition of surfaces having information and energy conversion tunctions. }\end{array}$ \\
\hline Nanomechanism & $1985-90$ & $\begin{array}{l}\text { Review the mechanisms and dynamics of matter in the nanometer (billionth of a meter) order from a } \\
\text { physical standpoint, and to search for clues for basic research and technology for measurement, } \\
\text { processing, fabrication, etc. }\end{array}$ \\
\hline Quantum magneto flux logic & $1986-91$ & $\begin{array}{l}\text { To research the basic structure and characteristics of elements and circuits which handle quantum } \\
\text { magneto fluxes; the method of environmental control such as complete magnetic shielding; and the } \\
\text { simulation of circuit operation, the method of constructing an information processing system, etc. }\end{array}$ \\
\hline $\begin{array}{l}\text { Molecular dynamic } \\
\text { assemblies }\end{array}$ & $1986-91$ & $\begin{array}{l}\text { Analyze fundamental dynamics by directly observing the motions of supramolecules and by measuring } \\
\text { inputs and outputs; search tor methods ot reconstituting supramolecules in vitro and exploring the } \\
\text { possibility of using them as biomolecular devices; and search for the principle of constructing } \\
\text { sophisticated systems that can sense, process, and judge external information. }\end{array}$ \\
\hline Biophotons & $1986-91$ & $\begin{array}{l}\text { Examine methods that can become the basis tor the measurement and analysis technology of biophotons; } \\
\text { analyze the substances that emit biophotons and study the photo-emission mechanism; measure and } \\
\text { analyze biophysical information on biophotons under various conditions; and explore the possibility of } \\
\text { applying the results to the measurement of biological organisms. }\end{array}$ \\
\hline
\end{tabular}

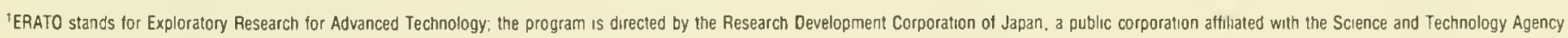
SOURCES Government of Japan. Science and Technology Agency, and the Tokyo Office of the U.S National Science Foundation 
Table C-2. Agency of Industrial Science and Technology (AIST) projects

\begin{tabular}{|c|c|c|c|}
\hline & Program/project & Period & Purpose \\
\hline & Basic Technologies for Future Industries & Varies per project & $\begin{array}{l}\text { To develop revolutionary basic technologies essential tor establishing new industries. Three } \\
\text { fields, with } 13 \text { subfields, are covered in the program; R\&D in these categories are } \\
\text { conducted until the materials involved are ready for practical application. }\end{array}$ \\
\hline & A. New materials & $1981-93$ & $\begin{array}{l}\text { The seven projects are high-performance ceramics, synthetic membranes for new separation } \\
\text { technology, synthetic metals, high-performance plastics, advanced alloys with controlled } \\
\text { crystalline structures, advanced composite materials, and photoactive materials. }\end{array}$ \\
\hline & B. Biotechnology & $1981-90$ & $\begin{array}{l}\text { The three projects in this category are bioreactor systems, large-scale cell cultivation, and } \\
\text { utilization of recombinant DNA. }\end{array}$ \\
\hline & C. New electronic devices & $1981-95$ & $\begin{array}{l}\text { The three projects in this category are superlattice devices, three-dimensional integrated } \\
\text { circuits, and bioelectronic devices. }\end{array}$ \\
\hline II. & The Large-Scale Project & $1966+$ & $\begin{array}{l}\text { Under this program, AIST conducts R\&D projects of particular importance to the nation. } \\
\text { Funds are contracted to participating companies, which work closely with national } \\
\text { laboratories and universities. Since 1966, } 24 \text { projects have been undertaken; } 16 \text { have been } \\
\text { completed, and } 8 \text { are in progress. }\end{array}$ \\
\hline & A. Manganese nodule mining & $1981-91$ & R\&D on a commercial scale hydraulic mining system. \\
\hline & $\begin{array}{l}\text { B. High-speed computing system for } \\
\text { scientific and technological uses }\end{array}$ & $1981-89$ & $\begin{array}{l}\text { R\&D on high-speed computing systems for applications that existing computers cannot } \\
\text { handle with adequate speed (e.g., processing satellite information, simulation of nuclear } \\
\text { fusion). }\end{array}$ \\
\hline & C. Advanced robot technology & $1982-90$ & $\begin{array}{l}\text { R\&D on advanced robot technology to support people working under dangerous conditions } \\
\text { (e.g., in nuclear power plants, disaster prevention). }\end{array}$ \\
\hline & D. Interoperable data base system & $1985-91$ & $\begin{array}{l}\text { R\&D on technology for interoperable information systems with such features as distributed } \\
\text { data bases and multi-media technology. }\end{array}$ \\
\hline & $\begin{array}{l}\text { E. Advanced material processing and } \\
\text { machining system }\end{array}$ & $1986-93$ & $\begin{array}{l}\text { R\&D on advanced surface processing using laser and/or ion beams for ultra-precision } \\
\text { mechanical processing for the energy, precision machining, and electronics industries. }\end{array}$ \\
\hline & The Sunshine Project & $1974+$ & $\begin{array}{l}\text { Ongoing R\&D projects to develop alternative energy-generating technologies including solar, } \\
\text { geothermal, coal, hydrogen, wind, and ocean thermal energy. }\end{array}$ \\
\hline IV. & The Moonlight Project & 1978-95 & $\begin{array}{l}\text { R\&O on energy conservation technology including energy storage and discharge (e.g., } \\
\text { advanced battery storage, superheat pump energy accumulation system) and ultra-efficient } \\
\text { energy generation (e.g., advanced gas turbine, fuel cell power generation, and high- } \\
\text { efficiency Stirling engines). }\end{array}$ \\
\hline
\end{tabular}




\section{awards under the specially promoted distinguished research program of the ministry of education}

\begin{tabular}{|c|c|c|c|}
\hline Year & Project title & Institution & Field \\
\hline 1982 & $\begin{array}{l}\text { Studies on New Digital Integrated Circuits Using Bridge-Type } \\
\text { Josephson Junction Devices }\end{array}$ & University of Tokyo & Engineering \\
\hline 1982 & $\begin{array}{l}\text { Relationship between Polymorphism of DNA Double Helix and Base } \\
\text { Configuration }\end{array}$ & University of Takyo & Pharmaceutics \\
\hline 1982 & Synthesis and Physical Properties of Artificial Lattice All & Kyoto University & Chemistry \\
\hline 1982 & $\begin{array}{l}\text { Studies on the Mechanism of Secretory Production of Useful Proteins } \\
\text { by Molecular Breeding of Bacillus subtilis }\end{array}$ & University of Tokyo & Agriculture \\
\hline 1982 & $\begin{array}{l}\text { Restructuring of Antibody Genes and Intormation Transfer Mechanism } \\
\text { in the Lymphocyte Differentiation Process }\end{array}$ & Osaka University & Medicine \\
\hline 1982 & $\begin{array}{l}\text { Studies on the Molecular Abnormalities of Blood Coagulation and } \\
\text { Fibrinolysis Factors }\end{array}$ & Kyushu University & Science \\
\hline 1983 & Elucidation of Social Interactive Processes by "Cognizance Theory" & Hokkaido University & Social Psychology \\
\hline 1983 & $\begin{array}{l}\text { Studies on Artificial Cleavages for the Exploitation of Deep Earth } \\
\text { Crystal Energy }\end{array}$ & Tohoku University & Mechanical Engineering \\
\hline 1983 & $\begin{array}{l}\text { Studies on Communication and Instrumentation by Heterodyne } \\
\text { Coherent Type Optical Fibers }\end{array}$ & University of Tokyo & Electrical Engineering \\
\hline 1983 & $\begin{array}{l}\text { Studies on the Origin and Evolution of Various Substances on the } \\
\text { Earth by Lanthanum Geologic Clocks, Rare Earth, and Radioisotopic } \\
\text { Tracers }\end{array}$ & University of Tokyo & Chemistry \\
\hline 1983 & $\begin{array}{l}\text { Direct Observation of Beauty Particles, and Detailed Studies on Charm } \\
\text { Particles by Automatic Particle Tracing Systems }\end{array}$ & Nagoya University & Physics \\
\hline 1983 & $\begin{array}{l}\text { Studies on Clustered Ion Beam Processes (tor Vapor Deposition and } \\
\text { Crystallinity Control) }\end{array}$ & Kyoto University & Electrical Engineering \\
\hline 1983 & $\begin{array}{l}\text { Studies on Behaviors of Microstructures of Magnetic Walls, and their } \\
\text { Application for Super-High Density Solid Memory Devices }\end{array}$ & Kyushu University & Electrical Engineering \\
\hline 1983 & $\begin{array}{l}\text { Nervous Processes tor Memory in Cerebellum and Mechanism for } \\
\text { Learning of Motion }\end{array}$ & University of Tokyo & Medicine \\
\hline
\end{tabular}




\begin{tabular}{|c|c|c|c|}
\hline Year & Project title & Institution & Field \\
\hline 1983 & $\begin{array}{l}\text { Molecular Genetic Studies on the Mechanism of Development of } \\
\text { Hypertension }\end{array}$ & Kyoto University & Immunology \\
\hline 1983 & $\begin{array}{l}\text { Studies on the Structure and Function of Acetylcholine Receptors and } \\
\text { Mechanism of Manifestation of Their Genes }\end{array}$ & Kyoto University & Medical Chemistry \\
\hline 1983 & $\begin{array}{l}\text { Biochemical and Genetic Studies on the Molecular Diversity of } \\
\text { Cytochrome P-450 Enzymes }\end{array}$ & Osaka University & Protein Physiology \\
\hline 1983 & $\begin{array}{l}\text { Systematic Search and Biochemical Studies of New Peptides with } \\
\text { Physiological Activity in Brain and Nervous Systems }\end{array}$ & Miyazaki Medical College & Biochemistry \\
\hline 1984 & Systematic Studies on Dense Kondo State Materials & University of Tokyo & Physics \\
\hline 1984 & $\begin{array}{l}\text { Rare Gas Geoscience: For Clarification of Evolution Processes of the } \\
\text { Earth Atmosphere, Ocean, and Mantle }\end{array}$ & University of Tokyo & Geophysics \\
\hline 1984 & $\begin{array}{l}\text { Determination of Physical Factors of Galaxy Structure by Newly- } \\
\text { Developed Quantitative Methods }\end{array}$ & University of Tokyo & Astronomy \\
\hline 1984 & $\begin{array}{l}\text { Investigation of Electronic Behaviors in Lattice-semi-matched } \\
\text { Heterostructures, and their Application to Low Power and Very High } \\
\text { Speed Devices }\end{array}$ & Tokyo Institute of Technology & Electronic System \\
\hline 1984 & Analysis of the Total Structure of Chloroplast DNA & Nagoya University & Bıology \\
\hline 1984 & Organization of Ionic Solutes in Solution and Their Fluctuation & Kyoto University & Polymer Chemistry \\
\hline 1984 & $\begin{array}{l}\text { Clarification of Molecular Mechanisms of Calmodulin; the Intra-cellular } \\
\text { Ionic Calcium-Receptor Protein }\end{array}$ & Osaka University & Higher Nervous Activity \\
\hline 1984 & $\begin{array}{l}\text { Studies on Expression of Genes by Chemically-synthesized Nucleic } \\
\text { Acid and on their Molecular Structural Recognition }\end{array}$ & Osaka University & Pharmaceutical Chemistry \\
\hline 1984 & $\begin{array}{l}\text { The Structure, Function and Medical Significance of the Inhibitor } \\
\text { Proteins Specific to Lysosmal-thiol-protease }\end{array}$ & Tokushima University & Enzyme Medicine \\
\hline 1985 & $\begin{array}{l}\text { Theoretical and Corroboratory Studies on Universality and Individuality } \\
\text { of Japanese Language }\end{array}$ & Tsuda College & Linguistics \\
\hline 1985 & $\begin{array}{l}\text { Establishment of Methodology for Archaeohistorical Studies Based on } \\
\text { Analyses of Data of Chronological Variation Patterns of Old Tree } \\
\text { Growth Rings }\end{array}$ & $\begin{array}{l}\text { Nara National Cultural Properties } \\
\text { Research Institute }\end{array}$ & Archaeology \\
\hline 1985 & $\begin{array}{l}\text { Development of New Systems for Observation of Surface Atomic } \\
\text { Configurational Structure, and Studies on Semiconductor Surface } \\
\text { Superlattice Structures }\end{array}$ & University of Tokyo & Solid State Physics \\
\hline 1985 & Search for Magnetic Monopoles and Other New Super Heavy Particles & University of Tokyo & Elementary Physics \\
\hline 1985 & $\begin{array}{l}\text { Quantum Hall Effects \& Localization of Valence Electrons: Quantum } \\
\text { Effects in Electrical Conduction }\end{array}$ & Gakushuin University & Physics \\
\hline 1985 & $\begin{array}{l}\text { Studies on Physical Characteristics of Interfaces Between Chemical } \\
\text { Compound Semiconductors and Insulators, and on Their Applications }\end{array}$ & Hokkaido University & Electrical Engineering \\
\hline 1985 & $\begin{array}{l}\text { Dynamic Structure and Functional Regulation of Protein Synthesis } \\
\text { Systems }\end{array}$ & University of Tokyo & Biophysics \\
\hline
\end{tabular}




\begin{tabular}{|c|c|c|c|}
\hline Year & Project title & Institution & Field \\
\hline 1985 & $\begin{array}{l}\text { Control Mechanisms in Biosynthesis of Blood-sugar-reducing and } \\
\text { Blood-pressure-lowering Peptides }\end{array}$ & Tohoku University & Medicine \\
\hline 1985 & $\begin{array}{l}\text { Elucidation of B-Lymphocyte Hyperplasia and Differentiation } \\
\text { Mechanisms and Studies on Their Anomaly Control }\end{array}$ & Osaka University & Cellular Engineering \\
\hline 1985 & Studies on Animal Cell Division Mechanisms & University of Tokyo & Cell Physiology \\
\hline 1985 & $\begin{array}{l}\text { Molecular Biological Studies on Functions and Regulatory } \\
\text { Mechanisms of Enzymes in Higher Animals }\end{array}$ & Kumamoto University & Biochemistry \\
\hline 1986 & $\begin{array}{l}\text { Integrated Historical and Demographic Studies on Pre-Modern Society } \\
\text { in Japan: An Analysis of Religious Denomination Conversion Records } \\
\text { and Development of A Computerized Database Thereof }\end{array}$ & Keio University & Economic History \\
\hline 1986 & $\begin{array}{l}\text { Studies on Methodologies for International Comparison of Human } \\
\text { Perceptions }\end{array}$ & Institute of Statistical Mathematics & Statistical Mathematics \\
\hline 1986 & $\begin{array}{l}\text { Studies on Microstructural Semiconductor Lasers and Two- } \\
\text { Dimensional Parallel Multi-layered Optical Integrated Circuits }\end{array}$ & Tokyo Institute of Technology & Laser Engineering \\
\hline 1986 & $\begin{array}{l}\text { Studies on Neutrino by Double Beta and Gamma Nuclear } \\
\text { Spectroscopy }\end{array}$ & Osaka University & Nuclear Physics \\
\hline 1986 & $\begin{array}{l}\text { Optical Properties of Quantum Wells Under Electrical Field and their } \\
\text { Applications to Uitra High Speed Optical Devices }\end{array}$ & Hiroshima University & Electronics \\
\hline 1986 & $\begin{array}{l}\text { Studies on Very Highly Ordered Molecular Systems to Achieve } \\
\text { Ultimate Functions }\end{array}$ & Kyoto University & Organic Chemistry \\
\hline 1986 & $\begin{array}{l}\text { Studies on Muscle Contraction Mechanism by Cryoelectron } \\
\text { Microscopy Utilizing Molecular and Heavy Atomic Labels }\end{array}$ & University of Tokyo & Biophysics \\
\hline 1986 & Mechanism of Protein Permeation and Secretion through Membranes & Nagoya University & Agricultural Chemistry \\
\hline 1986 & $\begin{array}{l}\text { Molecular Genetic Studies of Multiformity Expression in } \\
\text { Immunological Systems }\end{array}$ & Kyoto University & Medical Chemistry \\
\hline 1986 & $\begin{array}{l}\text { Genetic Information Retention Mechanism and Mutation Control } \\
\text { Mechanism }\end{array}$ & Kyushu University & Molecular Genetics \\
\hline
\end{tabular}

SOURCE. Government of Japan, Ministry of Education. Science, and Culture 

DO YOU WISH TO CONTINUE TO RECEIVE INTERNATIONAL REPORTS FROM THE DIVISION OF SCIENCE RESOURCES STUDIES?

$\square$ YES

$\square$ NO

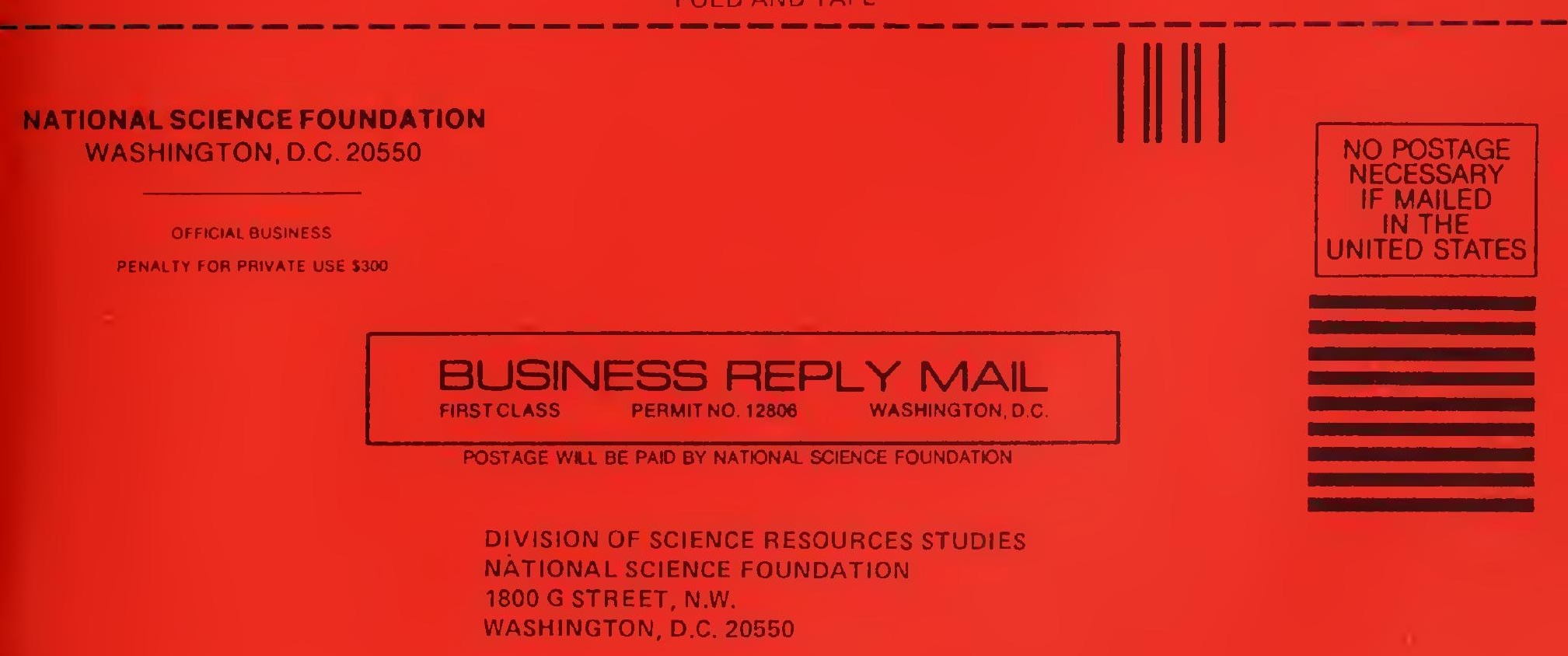




\section{NATIONAL SCIENCE FOUNDATION}

WASHINGTON D.C 20550

OFFICIAL BUSINESS

PENALTY FOR PAIVATE USE $\$ 300$

RETURP THIS COVER SHEET TO ROOM 233. IF YOU DO NOT WISH TO RECEIVE THIS MATERIAL 7 OR IF CHANGE OF ADORESS IS NEEDED INDICATE CHANGE, INCLUDING ZIP CODE ON THE LABEL 100

NOT REMOVE LABEL)

POSTAGE ANO FEESPAID NATIONAL SCIENCE FOUNDATION 